\title{
Evaluation of Ground-Water Degradation Resulting from Waste Disposal to Alluvium
} near Barstow, California

G E O L O G I C A L S U R V E Y PR O F E S I O N A L P A P E R 878

Prepared in cooperation with the

U.S. Marine Corps and the

California Water Resources Control Board

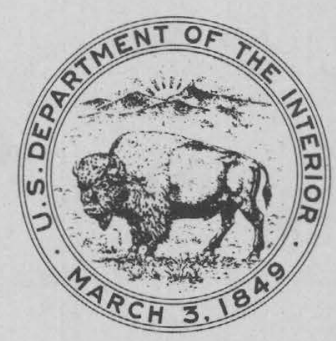





\section{Evaluation of Ground-Water Degradation Resulting from Waste Disposal to Alluvium near Barstow, California}

By JERRY L. HUGHES

GE OLOG I C A L S U R V E Y PR O F E S I O N A L PA P E R 878

Prepared in cooperation with the

U.S. Marine Corps and the

California Water Resources Control Board

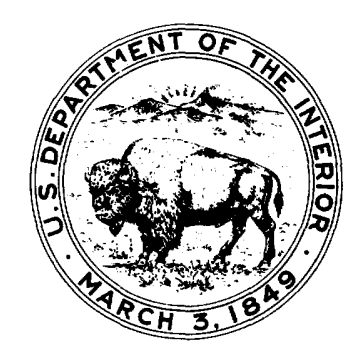




\title{
UNITED STATES DEPARTMENT OF THE INTERIOR \\ STANLEY K. HATHAWAY, Secretary
}

\section{GEOLOGICAL SURVEY}

\author{
V. E. McKelvey, Director
}

Library of Congress Cataloging in Publication Data

Hughes, J. L.

Evaluation of ground-water degradation resulting from waste disposal to alluvium near Barstow, California.

(Geological Survey Professional Paper 878)

Bibliography: p. 33

Supt. of Docs. No.: I 19.16:878

1. Water, Underground-Pollution-Barstow region, Calif. I. United States. Marine Corps. II. California. State Water Resources Control Board. III. Title: Evaluation of ground-water degradation... IV. Series: United States. Geological Survey. Professional Paper 878.

TD224.C3H83 $363.6^{\prime} 1$

$75-619167$

For sale by the Superintendent of Documents, U.S. Government Printing Office Washington, D.C. 20402

Stock Number 024-001-02694-5 


\section{CONTENTS}

\begin{tabular}{|c|c|}
\hline Page & Page \\
\hline Abstract & Sources of ground-water degradation-Continued \\
\hline Introduction _. & Industrial and domestic waste-Continued \\
\hline Geographic setting & U.S. Marine Corps Supply Center, Nebo $\ldots .$. \\
\hline Well-numbering system & Mining and milling operations \\
\hline Water-quality definitions and standards & Irrigation return \\
\hline Methods of investigation & Distribution and evaluation of chemical substances affecting \\
\hline Field methods & ground-water degradation \\
\hline Analytical methods & Dissolved solids \\
\hline Geohydrology - & Detergents (as MBAS) \\
\hline Ground-water geology & Dissolved organic carbon \\
\hline Ground-water hydrology & Nitrogen \\
\hline Sources of ground-water degradation & Chloride \\
\hline Natural & Effect of pumpage on water quality at the USMC Supply Center 29 \\
\hline Industrial and domestic waste & Rate of ground-water movement \\
\hline City of Barstow & Summary \\
\hline Atchison, Topeka and Santa Fe Railway & Selected references \\
\hline
\end{tabular}

\section{ILLUSTRATIONS}

FIGURE 1. Index maps showing location of project area

2. Graphs showing comparison of streamflow in Mojave River at Barstow with water levels in well $9 \mathrm{~N} / 1 \mathrm{E}-18 \mathrm{E} 1 \ldots$

3. Map showing geology, waste-disposal sites, wells used to sample ground-water quality, and water-level contours for 1945 and spring 1972

4. Schematic diagram showing water use in project area

5. Graphs showing change in concentration of selected chemical constituents in wells $9 \mathrm{~N} / 1 \mathrm{~W}-9 \mathrm{H} 5,-9 \mathrm{H} 7$, and $-10 \mathrm{~J} 3$

6. Sections showing vertical distribution of dissolved solids

7. Map showing areal distribution of DOC (dissolved organic carbon) and detergents (as MBAS)

8-11. Sections showing vertical distribution of:

8. Detergents (as MBAS)

9. Dissolved organic carbon

10. Nitrogen -

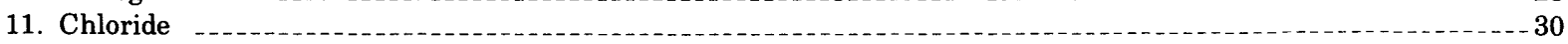

12. Graphs showing fluctuation of dissolved solids in well $9 \mathrm{~N} / 1 \mathrm{~W}-13 \mathrm{E} 1$ (Nebo 4 ) and water-supply demands at the Marine

Corps Supply Center (Nebo)

13. Map showing area affected by a 96 -hour aquifer test at U.S. Marine Corps Supply Center

\section{TABLES}

TABLE 1. Drinking-water standards

2. Water budget

3. Chemical analyses of the domestic wastes of the city of Barstow

4. Chemical analyses of the industrial wastes of the Atchison, Topeka and Santa Fe Railway

5. Chemical analyses of the domestic and industrial wastes of the U.S. Marine Corps Supply Center (Nebo) _............. 18

6. Chemical analyses of mining wastes

7. Comparison of water quality in shallow and deep test wells at USMC Supply Center golf course

8. Data on USMC Supply Center wells (Nebo) 


\section{CONVERSION FACTORS}

Factors for converting English units to the International System of Units (SI) are given below to four significant figures. However, in the text the metric equivalents are shown only to the number of significant figures consistent with the values for the English units.

\author{
English \\ acre \\ acre-ft (acre-foot) \\ acre-ft (acre-foot) \\ $\mathrm{ft}$ (foot) \\ $\mathrm{ft}$ (foot) \\ $\mathrm{ft} / \mathrm{mi}$ (feet per mile) \\ gal (gallon) \\ $\mathrm{gal} / \mathrm{min}$ (gallon per minute) \\ in. (inch) \\ $\mathrm{Mgal} / \mathrm{d}$ (million gallons per day) \\ mi (mile) \\ $\mathrm{mi}^{2}$ (square mile)
}

Multiply by

$4.047 \times 10^{-1}$

$1.233 \times 10^{-3}$

$1.233 \times 10^{3}$

$3.048 \times 10^{1}$

$3.048 \times 10^{-1}$

$1.890 \times 10^{-1}$

$3.785 \times 10^{-3}$

5.451

2.540

$3.785 \times 10^{3}$

1.609

2.590
Metric (SI)

ha (hectare)

$\mathrm{hm}^{3}$ (cubic hectometre)

$\mathrm{m}^{3}$ (cubic metre)

$\mathrm{cm}$ (centimetre)

$\mathrm{m}$ (metre)

$\mathrm{m} / \mathrm{km}$ (metre per kilometre)

$\mathrm{m}^{3}$ (cubic metre)

$\mathrm{m}^{3 / \mathrm{d}}$ (cubic metre per day)

$\mathrm{cm}$ (centimetre)

$\mathrm{m}^{3 / d}$ (cubic metre per day)

$\mathrm{km}$ (kilometre)

$\mathrm{km}^{2}$ (square kilometre) 


\title{
EVALUATION OF GROUND-WATER DEGRADATION RESULTING FROM WASTE DISPOSAL TO ALLUVIUM NEAR BARSTOW, CALIFORNIA
}

\author{
By Jerry L. Hughes
}

\begin{abstract}
Part of the alluvial aquifer along the Mojave River near Barstow, Calif., has been subjected to pollution from percolation of industrial wastes and municipal sewage for nearly 60 years. Effluent discharges have contained high concentrations of detergents, nitrogen, chromium, oil and grease, phosphates, phenols, and other organic and inorganic chemical substances. The poor quality ground water resulting from the discharge of these wastes has forced abandonment of several domestic wells because of taste, odor, and foaming and is endangering a well field serving the U.S. Marine Corps Supply Center at Nebo. The nature and occurrence of the degraded ground water, which is moving in very permeable river-channel deposits at an estimated rate of $1.0-1.5 \mathrm{ft}(30-45 \mathrm{~cm})$ per day, is described and outlined both areally and vertically. The concentration of dissolved solids, detergents, dissolved organic carbon, total nitrogen, and chloride were studied in three dimensions.

The distribution of chemical constituents in the ground water indicates that a plume of degraded water, produced by percolation from abandoned waste-disposal facilities near Barstow, is moving near the base of the aquifer. Since 1910 this degraded plume has moved downgradient about $4 \mathrm{mi}(6.4 \mathrm{~km})$. A more recent overlying plume of degraded water occurs near the downstream edge of the deeper plume. This overlying plume is produced by percolation from sewage-treatment facilities installed in 1968. Concentrations of detergents in ground water beneath this waste-disposal facility reflect the current use of readily biodegradable linear alkylate sulfonate type detergents, in contrast to the nonbiodegradable alkyl benzene sulfonate types in the deeper plume.

The concentration and distribution of nitrogen and chloride in ground water in the vicinity of the U.S. Marine Corps golf course suggest that the gradual increase in dissolved solids in the Marine Corps wells is in part due to the use of treated sewage effluent on the golf course. Areal and vertical mapping of the degraded water indicates that the water supply at the Marine Corps Supply Center will also be affected by the degraded water in the river-channel deposits if no corrective measures are taken.
\end{abstract}

\section{INTRODUCTION}

In many arid regions ground water in alluvial aquifers is commonly the only reliable source for man's water requirements. These aquifers have also constituted a convenient "out of sight-out of mind" medium for disposal of municipal and industrial wastes. These practices may effectively meet immediate water-supply and disposal requirements but later they can produce a legacy of ground-water quality problems that must be faced not only by future generations, but, in some cases, by the same entities and individuals responsible for the degradation.

Ground-water degradation in the alluvial aquifer near Barstow is endangering the well field that is the source of water for the USMC (U.S. Marine Corps) Supply Center at Nebo. Water managers in the area have been aware that a ground-water quality problem existed, but they had no adequate data for implementing effective management practices designed to alleviate the problem. The chemical nature, the horizontal and vertical extent of the degraded plume, and the dynamic characteristics of the hydrologic system must be understood before proper corrective measures can be taken.

In June 1971 the U.S. Geological Survey began an investigation of ground-water degradation near Barstow, Calif. The project area is in the lower and middle Mojave River basin, San Bernardino County, about $95 \mathrm{mi}(155 \mathrm{~km})$ northeast of Los Angeles. The general study area is about $200 \mathrm{mi}^{2}\left(520 \mathrm{~km}^{2}\right)$ and includes the reach of the Mojave River from above Barstow to below the USMC Supply Center at Nebo (fig. 1).

The Mojave River at Barstow is dry except during periods of flooding. The flooding is caused by heavy precipitation on the mountainous areas $50 \mathrm{mi}(80 \mathrm{~km})$ to the southwest. Precipitation at Barstow averages about 5 in. $(13 \mathrm{~cm})$ per year and produces negligible ground-water recharge. Wells perforated in younger and older alluvial deposits of Holocene and Pleistocene age are the only dependable source of water for the area's main water users (the city of Barstow and the USMC Supply Center at Nebo). The water supply for the city of Barstow is derived from wells in the younger alluvium north and west of the city where the chemical quality of ground water is generally good. The USMC supply wells are in the younger alluvial aquifer about 4 $\mathrm{mi}(6.4 \mathrm{~km})$ southeast of Barstow. 


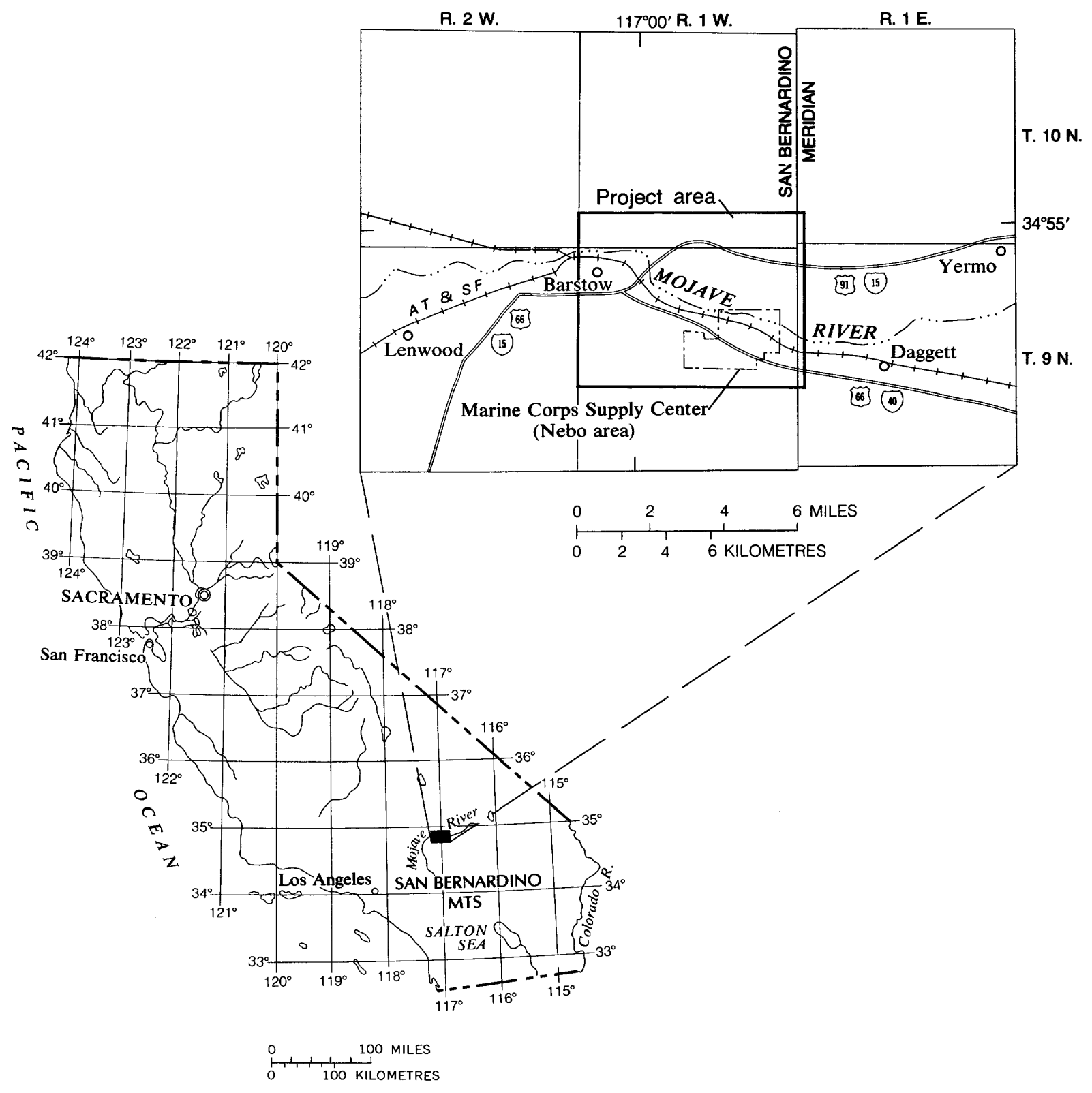

FIGURE 1.-Location of project area.

Since the early 1950 's, the chemical quality of ground water along the Mojave River for about $4 \mathrm{mi}(6.4 \mathrm{~km})$ southeast of Barstow has deteriorated significantly. The first recorded complaint of objectionable taste and odor was in 1952. Additional complaints about the quality of the ground water resulted in abandoning several wells. Chemical analyses of water samples from these wells indicated that the ground water in this area had degraded. A series of investigations by the California Department of Public Works (1952), California Department of Public Health and California Department of Water Resources (1960), and California Department of Public Health $(1966,1970)$ indicated that the degradation had resulted from local municipal and industrial waste disposal. The areas of degraded ground water were delineated on the basis of taste, odor, and the presence of detergents. A comparison of the degraded areas in each of the above reports indicated that the degraded ground water was moving downgradient toward the well field at the USMC Supply Center. Should the degraded water appreciably affect the quality of the water pumped at the USMC Supply Center, it would be necessary to treat or obtain water from other sources at considerable cost.

The purpose of this study was to identify and describe the areas of degraded ground water and to evaluate the 
potential effect on the quality of water pumped from the well field at the USMC Supply Center. This objective required an investigation of the aquifer system and identification of the chemical nature of the ground water with particular emphasis on the areal and vertical distribution of the degraded water and its rate and direction of movement.

The scope of the study included: (1) Collecting hydrologic, geologic, and chemical data from published and unpublished sources; (2) augering sufficient test wells that, when combined with existing irrigation and domestic wells, would provide a network of sampling points encompassing the areas of degraded ground water; (3) collecting and analyzing water samples from selected wells; (4) establishing a monthly program for ground-water quality sampling and water-level measurement for selected wells; and (5) performing an aquifer-evaluation test at the USMC Supply Center.

Some of the hydrologic interpretation used in this report was provided by S. G. Robson, who concurrently investigated the feasibility of utilizing digital-modeling techniques for studying ground-water quality (Robson, 1974). The model simulates the behavior of dissolvedsolids concentration in ground water. The Barstow area, in large part, was selected for the model study because of the abundant hydrologic and chemical data generated by this study. These data are tabulated in a separate report entitled "Selected Data on Wells in the Barstow Area, Mojave River Basin, California" (Hughes and Patridge, 1973).

The author thanks the many persons who have kindly given time, information, and guidance during the study and in the preparation of this report. The following agencies and firms provided data and made this report possible: Atchison, Topeka and Santa Fe Railway Co.; Betz Laboratories; Brown and Caldwell, Consulting Engineers; California Department of Public Health; California Department of Water Resources; City of Barstow; Mojave Water Agency; Nalco Chemical Co.; Neste, Brudin, and Stone, Consulting Engineers; San Bernardino County Flood Control District; Southern California Edison Co.; Southern California Water Co.; U.S. Marine Corps, Nebo Annex; and U.S. Navy, San Diego.

Particular thanks are given to D. L. Patridge, Geological Survey, for his assistance in collecting and organizing the large quantities of data necessary for this report. Other persons in the Geological Survey who contributed time and knowledge in interpretation of data include S. G. Robson, C. O. Morgan, G. A. Miller, G. G. Ehrlich, and L. A. Eccles.

\section{GEOGRAPHIC SETTING}

The Mojave River is the main source of recharge to local aquifers. The river, which traverses the project area from west to east (fig. 1), originates in the San Bernardino Mountains about $50 \mathrm{mi}(80 \mathrm{~km})$ southwest of Barstow and empties into playa lakes about $60 \mathrm{mi}$ (96 $\mathrm{km}$ ) east of Barstow (Miller, 1969). Tributary inflow to the Mojave River is very small in the reach downstream from the San Bernardino Mountains, and the streambed is dry near Barstow except during infrequent periods of heavy runoff.

The climate in the lower and middle Mojave River basin is arid; average annual precipitation is less than 5 in. $(13 \mathrm{~cm}$ ) (data from U.S. National Weather Service, 1972). The primary source of ground-water recharge to the Mojave River aquifer system is precipitation on and subsequent runoff from the San Bernardino Mountains. Annual precipitation in the San Bernardino Mountains is greater than in any other area of southern California, sometimes exceeding 75 in. $(190 \mathrm{~cm})$. During 1969 rainfall at Barstow was 1.0 in. $(2.5 \mathrm{~cm})$ in January and 2.2 in. $(5.6 \mathrm{~cm})$ in February, yet rainfall in the San Bernardino Mountains was sufficient to produce streamflow at Barstow in excess of 120,000 acre-ft ( 150 $\mathrm{hm}^{3}$ ) (Hardt, 1969, p. 5). Excluding the wet year of 1969 , records of flow in the Mojave River at Barstow indicate a comparatively dry period since 1948 (fig. 2). During 1932-48, floodflows in the Mojave River provided large quantities of water for ground-water recharge.

The frost-free growing season in the Barstow area is about 250 days. Temperatures below freezing often occur between November and March. Midafternoon temperatures during July and August are frequently above $100^{\circ} \mathrm{F}\left(38^{\circ} \mathrm{C}\right)$.

In arid and semiarid regions, the quantity of water that evaporates from soil and that is transpired by plants generally is less than the potential evapotranspiration because water is not usually readily available. Thornthwaite (1948) devised a method for computing evapotranspiration based on mean monthly temperatures and latitude of the area. Hardt (1971, p. 7) compared evapotranspiration computed by the Thornthwaite method with mean monthly precipitation for the Mojave River basin and found that precipitation exceeds potential evapotranspiration only during 3 months of the year-December, January, and February. The potential evapotransporation was estimated to be 35 in. $(89 \mathrm{~cm})$ per year or about seven times greater than mean annual precipitation.

\section{WELL-NUMBERING SYSTEM}

Wells are numbered according to their location in the rectangular system for subdivision of public land. As shown by the diagram, that part of the number preceding the slash, as in $9 \mathrm{~N} / 1 \mathrm{~W}-9 \mathrm{~B} 1$, indicates the township (T. $9 \mathrm{~N}$.); the number following the slash 

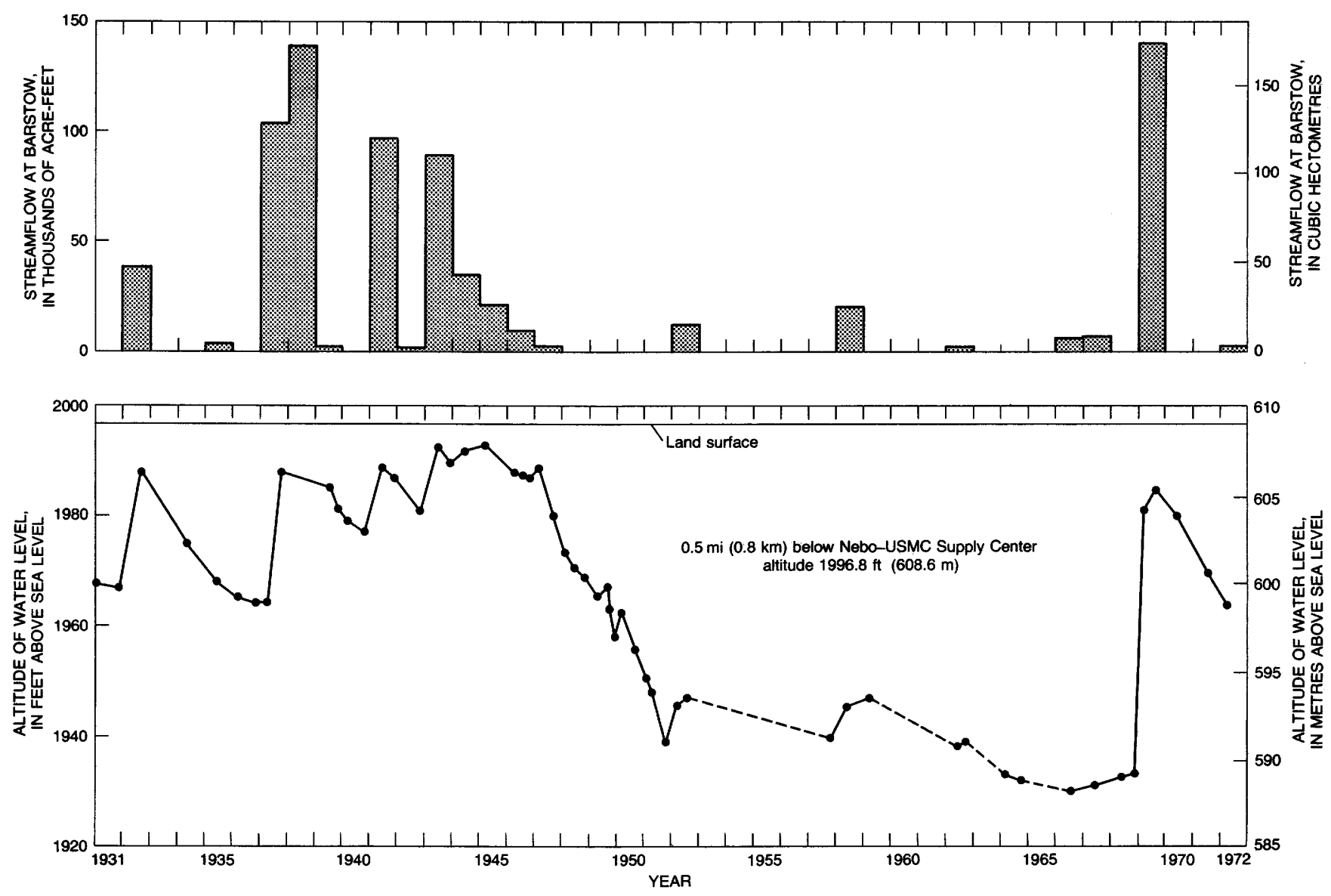

Figure 2.-Comparison of streamflow in Mojave River at Barstow with water levels in well 9N/1E-18E1.

indicates the range (R. $1 \mathrm{~W}$.); the number following the dash indicates the section (sec. 9); the letter following the section number indicates the 40-acre (16.2-ha) subdivision according to the lettered diagram. The final digit is a serial number for wells in each 40-acre (16.2-ha) subdivision. The area covered by this report lies east and west of the San Bernardino meridian and north of the San Bernardino base line.

\section{WATER-QUALITY DEFINITIONS AND STANDARDS}

Terms commonly used to identify conditions of water quality include degradation, pollution, and contamination. Because these qualitative terms are sometimes considered synonymous, definitions used in this report will generally follow those given in the 1969 PorterCologne Water Quality Control Act of the State of California. Briefly, they are: degradation-a general term used to identify water quality that has been impaired for use but not necessarily to a degree that prohibits its beneficial use; pollution-a condition of water quality resulting from use that limits its further beneficial use; contamination - water that is generally considered a hazard to public health because of its content of poisonous constituents or disease-causing organisms.

To evaluate the quality of water in the Barstow area,

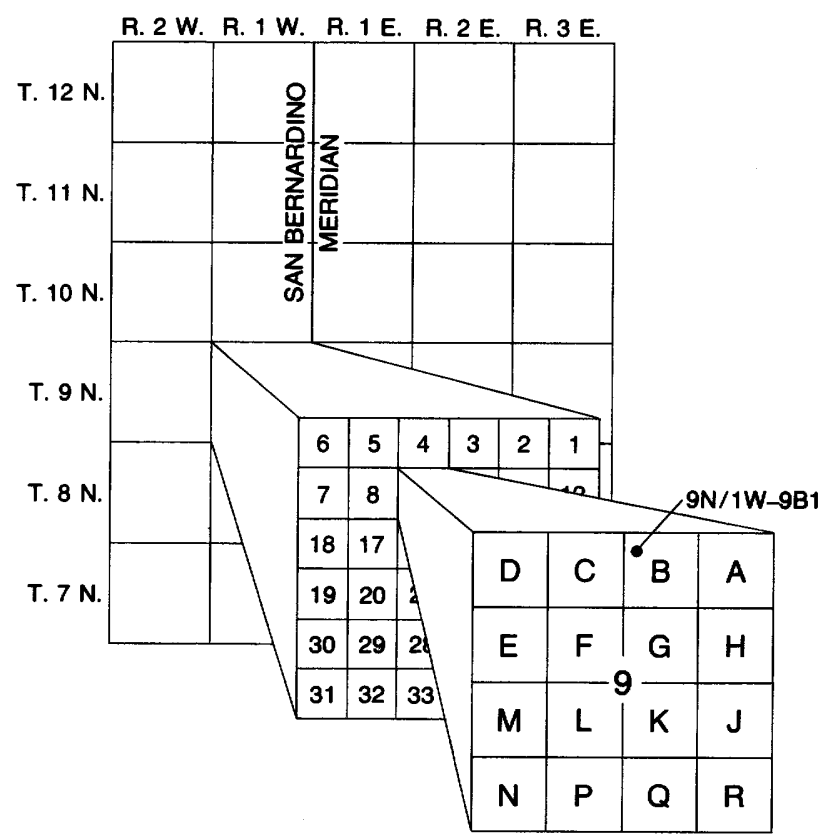


TABLE 1-Drinking water standards

[Modified from American Water Works Association (1971, p. 20-32); constituents in milligrams per litre]

\begin{tabular}{|c|c|c|c|c|c|c|c|}
\hline \multirow{2}{*}{ Chemical constituents } & \multicolumn{2}{|c|}{$\begin{array}{l}\text { U.S. Public Health Service } \\
\qquad 1962\end{array}$} & \multicolumn{2}{|c|}{$\begin{array}{l}\text { World Health Organization } \\
\text { European, } 1961\end{array}$} & \multicolumn{3}{|c|}{$\begin{array}{l}\text { World Health Organization, International } \\
\qquad 1963\end{array}$} \\
\hline & $\underset{\text { limit }^{1}}{\text { Recommended }}$ & $\begin{array}{c}\text { Tolerance } \\
\text { limit }^{1}\end{array}$ & $\underset{\text { limit }^{1}}{\text { Recommended }}$ & $\begin{array}{l}\text { Tolerance } \\
\text { limit }\end{array}$ & $\underset{\text { limit }^{1}}{\text { Recommended }}$ & $\begin{array}{l}\text { Acceptable } \\
\text { limit }^{1}\end{array}$ & $\begin{array}{c}\text { Tolerance } \\
\text { limit }^{1}\end{array}$ \\
\hline $\begin{array}{l}\text { Alkyl benzene sulfonate (ABS) } \\
\text { Ammonia } \\
\text { Arsenic (As) } \\
\text { Barium (Ba) } \\
\text { Boron }^{2} \text { (B) }\end{array}$ & $\begin{array}{c}0.5 \\
-.01 \\
-1.0\end{array}$ & $\begin{array}{l}-0 .- \\
0 \\
1.0\end{array}$ & \begin{tabular}{c|c}
-0.5 \\
---- \\
-----
\end{tabular} & 0.2 & 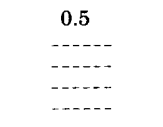 & $\begin{array}{ll}1.0 \\
-\cdots-1 \\
---1- \\
-\cdots-\end{array}$ & $\begin{array}{l}0.05 \\
1.0 \\
-\cdots\end{array}$ \\
\hline $\begin{array}{l}\text { Cadmium }(\mathrm{Cd}) \\
\text { Calcium }(\mathrm{Ca}) \\
\text { Carbon chloroform extract }(\mathrm{CCE}) \\
\text { Carbon dioxide, free }\left(\mathrm{CO}_{2}\right) \\
\text { Chloride }(\mathrm{Cl})\end{array}$ & $250^{-2--}$ & $\begin{array}{r}.01 \\
---- \\
---\cdot- \\
----\end{array}$ & $\begin{array}{c}3-1 \\
0 \\
350\end{array}$ & 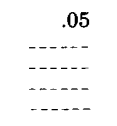 & $200^{75}$ & $600^{200}$ & $\begin{array}{r}.01 \\
-\cdot-\cdot \\
-\cdots-1 \\
-\cdots--\end{array}$ \\
\hline $\begin{array}{l}\text { Chromium, hexavalent }\left(\mathrm{Cr}^{+6}\right) \\
\text { Copper (Cu) } \\
\text { Cyanide (CN) } \\
\text { Dissolved solids (DS) } \\
\text { Fluoride (F) }\end{array}$ & $\begin{array}{c}1.0 \\
500 \\
5,6.8-1.7\end{array}$ & $\begin{array}{c}.05 \\
.2 \\
51 . \overline{4-2.4}\end{array}$ & $\begin{array}{l}{ }^{4} 3.0 \\
---1.5 \\
1.5\end{array}$ & 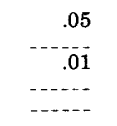 & \begin{tabular}{l}
1.0 \\
\hdashline-1 \\
$-\cdots-1$
\end{tabular} & $1.0-1.5$ & $\begin{array}{c}.05 \\
-2 \\
-2 \\
-\cdots--\end{array}$ \\
\hline $\begin{array}{l}\text { Hardness }\left(\mathrm{as} \mathrm{CaCO}_{3}\right) \\
\text { Hydrogen ion concentration }(\mathrm{pH}) \\
\text { Iron }(\mathrm{Fe}) \\
\text { Lead }(\mathrm{Pb}) \\
\text { Magnesium }(\mathrm{Mg})\end{array}$ & 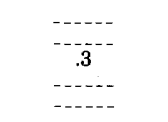 & 05 & ${ }^{7100-500}{ }^{10} .1$ & 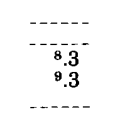 & $\begin{array}{r}77.0-8.5 \\
.3 \\
50\end{array}$ & $\begin{array}{c}76.5-9.2 \\
1.0 \\
150\end{array}$ & $\begin{array}{cc}05 \\
-\cdots+1\end{array}$ \\
\hline $\begin{array}{l}\text { Magnesium + sodium sulfate } \\
\text { Manganese }(\mathrm{Mn}) \\
\text { Nitrogen }(\mathrm{N}) \text {, Nitrite }+ \text { Nitrate }^{2} \\
\text { Oxygen, dissolved }\left(\mathrm{O}_{2}\right) \\
\text { Phenolic compounds (as phenol) }\end{array}$ & $\begin{array}{l}.05 \\
10.0 \\
.001\end{array}$ & $\begin{array}{l}-\cdots- \\
-\cdots \\
---- \\
----\end{array}$ & .001 & 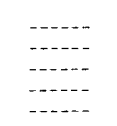 & $\begin{array}{l}500 \\
.1 \\
-001\end{array}$ & $\begin{array}{c}1,000 \\
.5 \\
-002\end{array}$ & 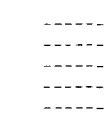 \\
\hline $\begin{array}{l}\text { Selenium }(\mathrm{Se}) \\
\text { Silver }(\mathrm{Ag}) \\
\left.\text { Sulfate }\left(\mathrm{SO}_{4}\right)\right) \\
\text { Zinc }(\mathrm{Zn})\end{array}$ & 250 & $\begin{array}{r}.01 \\
.05 \\
\hdashline---\end{array}$ & $250^{5}$ & $\begin{array}{r}.05 \\
----- \\
-\cdots--\end{array}$ & $200^{-\cdots-}$ & 400 & $\begin{array}{r}.01 \\
-\cdots \\
-\cdots-1\end{array}$ \\
\hline \multicolumn{3}{|c|}{$\begin{array}{l}{ }^{1} \text { Recommended limit: } \\
\text { USPHS: Concentrations which should not be exceeded where more suitable water } \\
\text { supplies are available. } \\
\text { wHO, European: Concentrations above which may give rise to esthetic and other } \\
\text { troublesome problems. } \\
\text { WHO, International: Concentrations which are generally satisfactory to the con- } \\
\text { sumer. } \\
\text { Acceptable limit: } \\
\text { WHO, International: Concentrations above which the potability of the water would be } \\
\text { "markedly" impaired. } \\
\text { Tolerance limit: } \\
\text { USPHS: Concentrations above which shall constitute grounds for rejection of the } \\
\text { supply. } \\
\text { WHO, European: Concentrations above which are likely to give rise to actual danger to } \\
\text { health. }\end{array}$} & \multicolumn{5}{|c|}{$\begin{array}{l}\text { WHO, International: Concentrations above which may give rise to actual danger to } \\
\text { health. } \\
\text { From U.S. Public Health Service Pub. } 1880,1969 \text {. } \\
\text { Concentrations in excess of } 0.2 \mathrm{mg} / 1 \text { indicate need for additional analyses to determine } \\
\text { the causative agent. } \\
\text { Recommended limit is } 0.05 \mathrm{mg} / 1 \text { for water entering the distribution system; } 3.0 \text { after } \\
16 \text {-hour contact with new pipes. } \\
\text { Dependent on annual average maximum daily air temperature over not less than a } \\
5 \text {-year period. } \\
\text { Where fluridation is practiced, minimum recommended limits are also specified. } \\
\text { Range, minimum to maximum limits. } \\
\text { In larger installations where removal of iron is economic, water entering the distribution } \\
\text { system should not contain more than } 0.1 \mathrm{mg} / 1 \text {. } \\
\text { Upper limit should be } 0.1 \mathrm{mg} / 1 ; 0.3 \text { permitted after } 16 \text {-hour contact with lead pipes. } \\
\text { Not more than } 30 \mathrm{mg} / 1 \text { if the sulfate content equals or exceeds } 250 \mathrm{mg} / 1 \text {. } \\
\text { Minimum concentration. }\end{array}$} \\
\hline
\end{tabular}

results of chemical analyses of waste effluent and ground water were compared with the generally accepted standards of water quality. The suitability of water for industrial, domestic, and irrigation use depends to a large extent on the type and total concentration of ions and compounds in solution. All widely recognized standards for drinking water specify that water used for drinking should be clear, colorless, odorless, pleasant to taste, and free from toxic compounds and pathogenic organisms. Probably the most widely used criteria in the United States for determining suitability of water for drinking are from the U.S. Public Health Service (1962), summarized in table 1. Drinking-water standards established by World Health Organization, European (1961) and World Health Organization, International (1963) are also summarized for comparison (Am. Water Works Assoc., 1971).

The standards summarized in table 1 are not to be confused with those established by the California Water Resources Control Board, Lahontan Region, for waste disposal to alluvium in the Barstow area. These discharge requirements are briefly discussed in this

report in the section on "Sources of Ground-Water Degradation."

\section{METHODS OF INVESTIGATION}

\section{FIELD METHODS}

During the latter part of 1971 and the first 6 months of 1972 , more than 50 test wells were augered in the river-channel deposits of the Mojave River. Most of these wells were located in areas of historic and current waste disposal and in areas where the ground water was reported to be degraded. A few wells were augered outside the above areas in order to better define the limits of the degraded ground water. Several well points, each at a different depth, were installed at most drill sites. Depths of the test wells ranged from 25 to 135 $\mathrm{ft}(7.6$ to $41 \mathrm{~m})$ below land surface.

All test wells completed for this project were cased with 2-in. $(5.08 \mathrm{~cm})$ I.D. (inside diameter) PVC (polyvinyl chloride) pipe with a screened well point attached at the bottom. Well points were $2 \mathrm{ft}(0.6 \mathrm{~m})$ 
long, $1 \frac{1 / 4}{4}$ in. $(3.175 \mathrm{~cm})$ in diameter, and number 18 slot (0.18-in. or 0.46 -cm opening). A 5 -ft (1.5-m) length of 2 -in. (5.08-cm) I.D. galvanized pipe was fitted to the top of each test well in order to minimize damage from vandalism and floods.

Several precautions were taken to avoid contamination of the test well during augering and development. The use of oil on bolts, auger flights, and other drill equipment was kept to a minimum. Wells were developed by lowering a weighted, flexible, 3/4-in. $(1.90-\mathrm{cm})$ PVC pipe into the test well and airlifting water from the well with compressed air. Development usually required an hour or more, generally at a rate of about $5 \mathrm{gal} / \mathrm{min}\left(25 \mathrm{~m}^{3} / \mathrm{d}\right)$. All test wells augered were allowed to equilibrate with the ground water a minimum of 60 days before sampling.

The sampling procedure involved the lowering of an air line to a place just above the well point where pumping by airlift began and was continued until discharge from the well was clear of sediment. The air line was then slowly raised to a level where discharge from the well was reduced to a near minimum. At this level the airlift compressor was operated for a period sufficient to insure that the discharge was free of sediment and that any water that might have been aerated by the deeper pumping had been removed. After washing all sampling apparatus, the air line was removed from the well and a flow-through, or selfwashing, thief sampler of 750-ml (millilitres) capacity was lowered to the top of the well point and a water sample taken. This thief sampler is a spring-loaded, teflon-sealed, brass cylinder open at both ends until triggered by a weighted messenger at the desired level of sampling.

Chemical analyses of ground-water samples collected directly from the airlift discharge differed from those taken with the thief sampler. These differences were attributed to the aeration associated with the airlift process which caused oxidation, precipitation, and accelerated aerobic degradation. Values of the chemical parameters compared were generally lower for the airlift method: field $\mathrm{pH}$ values were higher (hydrogen ion concentration lower); calcium, magnesium, chromium, and iron were lower; ammonia, phosphate, dissolved organic carbon, and particularly the MBAS (methyl blue active substances) values were lower, especially in the samples thought to contain the newer biodegradable LAS (linear alkylate sulfonate) detergents.

\section{ANALYTICAL METHODS}

During this investigation about 150 water samples from wells were analyzed. Analysis included the major anions and cations plus arsenic, phosphate $\left(\mathrm{PO}_{4}\right)$, ammonia $\left(\mathrm{NH}_{3}\right.$ as $\left.\mathrm{N}\right)$, chemical oxygen demand (COD), oil and grease, detergents (as MBAS), hexavalent chromium $\left(\mathrm{Cr}^{+6}\right)$, and dissolved organic carbon (DOC). Copper $(\mathrm{Cu})$, mercury $(\mathrm{Hg})$, and chromium $\left(\mathrm{Cr}^{+3}\right)$ were analyzed in samples from selected wells.

During the course of sampling, several laboratories were selected for a cross-check of sample analyses. The results of this check indicated that laboratory results were generally satisfactory except for analysis of some of the nonconservative biodegradable constituents. The geographically closest laboratory was selected to analyze these biodegradable constituents to reduce the time period for handling; this laboratory also produced the most consistent results.

Most of the common constituents (major anions and cations) were analyzed by the Geological Survey central laboratory, Salt Lake City, Utah. The procedures used for filtering and preserving samples complied with analytical techniques that are described by the American Public Health Association (1971). Water samples to be analyzed for the nonconservative, biodegradable chemical compounds were delivered from the field to the State of California Public Health Laboratory in Los Angeles within 48 hours.

The presence of hexavalent chromium, a readily reduced ion, was determined in the field by adding 2.5 $\mathrm{ml}$ of diphenylcarbozide to a $50-\mathrm{ml}$ aliquot of sample. The mixture was allowed to stand for 5 minutes, and a pink to red coloration indicated the presence of hexavalent chromium. Samples containing hexavalent chromium were sent to the California Public Health Laboratory for quantitative analysis. One of the chemical constituents determined in all samples was the synthetic surfactant constituent in detergents. The method for determination of detergents is by MBAS. This method does not distinguish among the several types of surfactants that may exist in water (American Public Health Association, 1971).

DOC (dissolved organic carbon) was a most useful parameter in locating areas affected by industrial- and domestic-waste disposal. DOC indicates the presence of water-soluble organic compounds. Water samples to be analyzed for DOC were stored at low temperature $\left(4^{\circ} \mathrm{C}\right)$ after filtration through a silver-membrane filter. Both the low temperature and the trace quantity of silver that were dissolved in the sample from the silvermembrane filter inhibited bacterial activity. Effects on analytical results from time delays between field sampling and laboratory analysis were less critical for DOC than for other nonconservative compounds because of the inhibited bacteria. All DOC samples were analyzed at the Geological Survey organic geochemistry laboratory in Denver, Colo. 


\section{GEOHYDROLOGY}

\section{GROUND-WATER GEOLOGY}

The ground-water geology of the project area has been described in previous reports by Thompson (1929); California Department of Water Resources (1967); Bader, Page, and Dutcher (1958); Page and Moyle (1960); Page, Moyle, and Dutcher (1960); Dyer, Bader, Giessner, and others (1963); Miller (1969); and others. In general, the surface geology of the highland areas (fig. 3) is characterized by outcrops of consolidated rocks of Tertiary and Quaternary age, which yield very little water-less than $100 \mathrm{gal} / \mathrm{min}\left(550 \mathrm{~m}^{3} / \mathrm{d}\right)$ - to wells. The lowland areas are characterized by unconsolidated alluvial deposits consisting of alluvium and fan deposits of Pleistocene age and alluvium and fan deposits of Holocene age. River-channel deposits are a part of the younger alluvium (Holocene) and compose much of the aquifer system studied in detail.

Data from more than 50 test wells augered during this study (fig. 3) indicate that the river-channel deposits are highly permeable and consist of moderately well-sorted, subrounded to subangular, fine to coarse sand and gravel. Wells in these deposits typically yield from several hundred to more than $1,000 \mathrm{gal} / \mathrm{min}(5,500$ $\mathrm{m}^{3} / \mathrm{d}$ ). Clay is uncommon in the river-channel deposits and where present occurs in thin $(0.5-1.5 \mathrm{ft}$ or $0.15-0.46$ $\mathrm{m})$ lenses. The hydraulic character of the younger alluvial deposits seems to approach that of a homogeneous and isotropic medium. Although stratification in sand layers may retard the vertical movement of ground water, well logs and water-level data collected during this project suggest that wide variations in vertical permeability are not of major consequence. Test wells were drilled to depths of as much as $150 \mathrm{ft}(45 \mathrm{~m})$; the contact with the underlying older alluvial deposits was not identified during drilling but is probably not much greater than $150 \mathrm{ft}(45 \mathrm{~m})$ below land surface.

The older alluvial (Holocene-Pleistocene?) deposits are poorly sorted and consist of clay, silt, sand, gravel, and boulders. They are locally cemented and generally yield small to moderate quantities of water to wells. Water in this aquifer is typically high in dissolved solids, boron, and fluoride (Hughes and Patridge, 1973). In the descriptions shown on most commercial well logs, the geologic contact between the younger river-channel deposits and the older, less permeable alluvium is not well defined. Many of the high-yielding wells in the project area probably derive water from a combination of river-channel deposits, alluvial-fan deposits, and older alluvial deposits. The lithologic log of well 9N/1W-14B3 (Koehler, 1969) suggests that intertonguing of river-channel deposits and alluvial-fan deposits occurs to depths of as much as $150 \mathrm{ft}$ (45 m). During a
1969 aquifer test on well 9N/1W-14B3, a deep-well flowmeter survey indicated that most of the yield was from the upper $150 \mathrm{ft}(45 \mathrm{~m})$ of these intertonguing deposits (well is perforated from 109 to $312 \mathrm{ft}$ or 33 to $95 \mathrm{~m}$ ).

The Waterman fault trends northwestward across the Mojave River along the east side of the USMC Supply Center (fig. 3) where its trace is buried by unfaulted surficial sediments. The upper limit of faulted or fault-affected river-channel deposits is not known. Differences in water levels across the fault of $45 \mathrm{ft}(14 \mathrm{~m})$ in 1965 (Miller, 1969) and $30 \mathrm{ft}(9 \mathrm{~m})$ in 1971 (Hughes and Patridge, 1973) have been observed.

\section{GROUND-WATER HYDROLOGY}

The alluvial aquifers near Barstow receive recharge as underflow from the west and south and from floodflow in the river. The principal direction of ground-water movement is eastward. Contours of ground-water levels (1972) indicate a gradient from west to east of $10-15$ $\mathrm{ft} / \mathrm{mi}(1.9-2.8 \mathrm{~m} / \mathrm{km})$ in the reach upstream from the Waterman fault, and a somewhat steeper gradient downstream from the fault (fig. 3). Long-term hydrographs indicate that water levels in wells in the younger alluvial aquifer reflect the intermittent surface flow in the Mojave River. Steady declines in the ground-water level in some areas exceed $40 \mathrm{ft}(12 \mathrm{~m})$ during dry periods when no surface flow occurs and may be followed by as much as $50 \mathrm{ft}(15 \mathrm{~m})$ of recovery during a year with ample floodflow in the Mojave River. Figure 2 illustrates the response of water levels in well $9 \mathrm{~N} / 1 \mathrm{E}-18 \mathrm{E} 1$ to floodflow in the Mojave River. This well is $88 \mathrm{ft}(27 \mathrm{~m})$ deep, is located adjacent to the river, and is reportedly perforated entirely in river-channel deposits.

Ground-water development in the Barstow area has resulted in a complex local system of recharge and discharge. The effect of this development has been to lower the water table (fig. 3), thereby reducing the volume of ground water in storage and the rate of ground-water flow eastward.

The water budget for the Barstow area can be divided into the following categories: (1) Recharge by underflow, surface water, sewage effluent, and irrigation return; and (2) discharge by underflow and pumpage (table 2).

Recharge by underflow is the subsurface inflow from the aquifers west of Barstow and from the much less permeable aquifer southeast of Barstow. Variations in this quantity of recharge represent changes in inflow due to changes in saturated thickness of the aquifers west of Barstow. The aquifer system south of Barstow is undeveloped, and available data suggest that the system has undergone very little change in head.

Recharge from effluent occurs where there is deep 


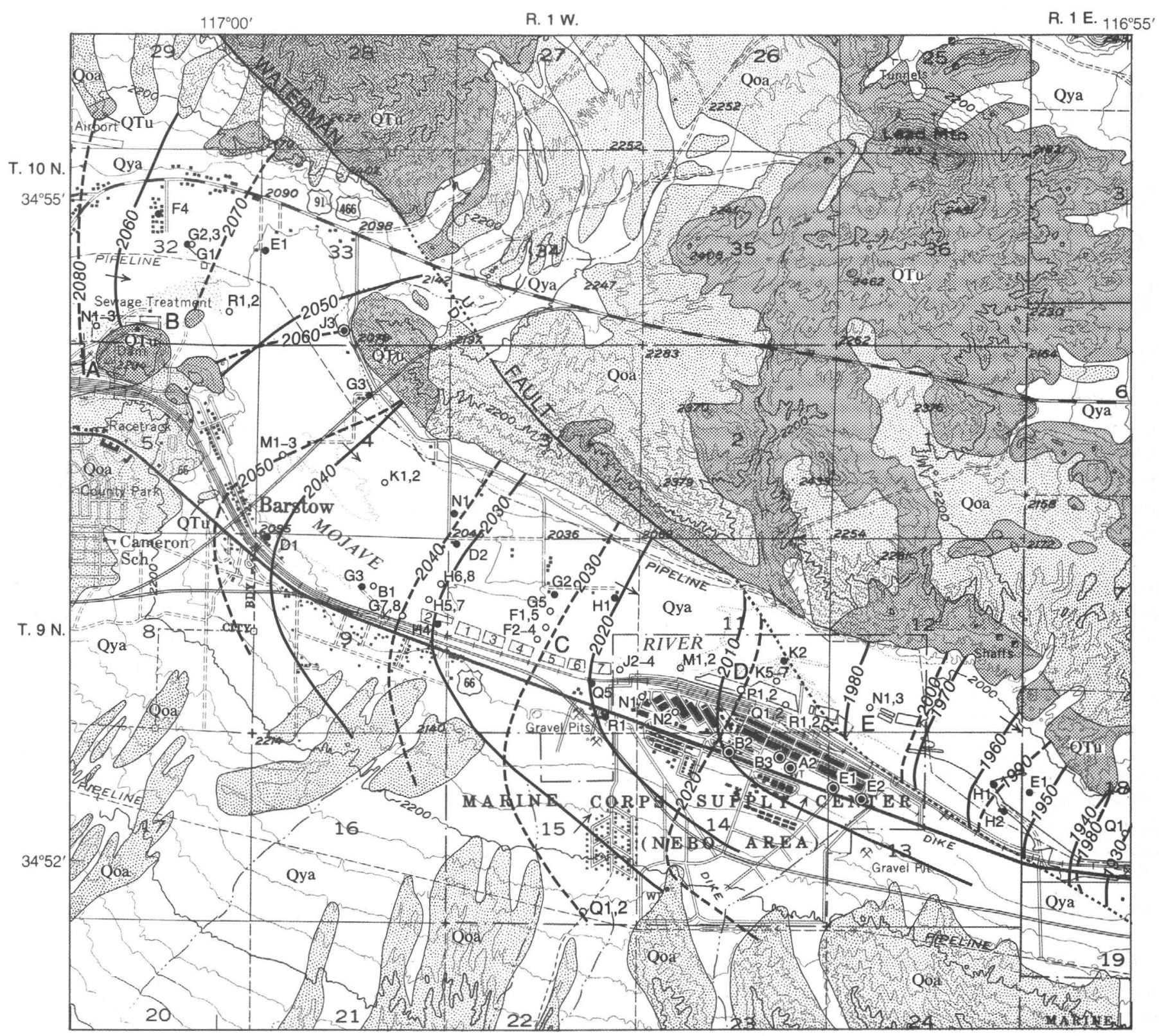

Base trom U.S. Geological Survey Barstow and Daggett 1:62 500, 1956 Roads as of 1972

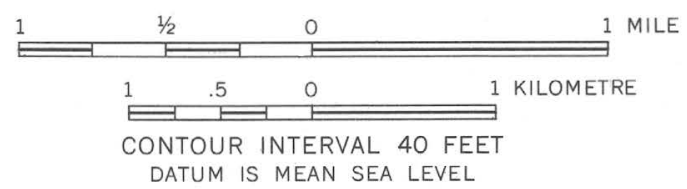

Geology modified after G.A. Miller, 1969

FIGURE 3.-Geology, waste-disposal sites, wells used to sample ground-water quality, and water-level contours for 1945 and spring 1972.

percolation of sewage-effluent water. This recharge originates from two main sources in the Barstow area: (1) The city and railroad sewage-treatment facilities (sites A, B, and C, fig. 3), and (2) the USMC sewage-treatment facilities (site D, fig. 3).

Discharge by underflow from the area occurs along the Mojave River northeast of the Waterman fault. The large variations in this quantity shown in table 2 are due to correspondingly large variations in the saturated thickness of the aquifer downstream from the fault.

The term "pumpage" as used in table 2 represents the net consumptive use of water extracted from the aquifer. When the pumping well is in the area of use, the quantity of extracted water that percolates and returns 
EXPLANATION

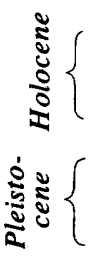

Consolidated rocks, undifferentiated

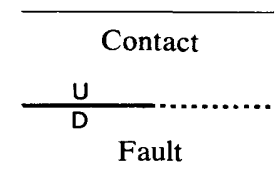

Dotted where concealed. U, upthrown side; D, downthrown side

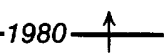

Water-level contour, 1972

Shows altitude of water level. Contour in terval $10 \mathrm{ft}(3 \mathrm{~m})$. Datum is mean sea level. Arrow shows direction of movement

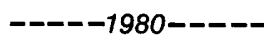

Water-level contour, 1945

Based on sparse measurements. Contour interval $10 \mathrm{ft}(3 \mathrm{~m})$. Datum is mean sea level.

\section{WASTE-DISPOSAL SITES}

\section{A}

City of Barstow (abandoned, 1953) A.T. and S.F. Railway (abandoned, 1968)

\section{B}

City of Barstow (abandoned, 1968)

\section{C}

City of Barstow

A.T. and S.F. Railway

D

USMC golf course

E

USMC Supply Center

$$
\text { oB1 }^{\mathrm{B} 1}
$$

Test well

-G3

Irrigation-domestic well

OB2

USMC-City of Barstow supply well to the aquifer was subtracted from the total to calculate the pumpage.

Evaluation of the volumes of recharge and discharge (table 2) indicates that for the 26-year period (1946-71), the volume of ground water in storage was reduced by an estimated 13,000 acre-ft $\left(16 \mathrm{hm}^{3}\right)$. The beneficial effects on ground water in storage by surface-water recharge during large floods are illustrated by omitting the 1969 flood recharge from the change in storage computations; under these conditions the compared decline in storage was approximately 32,000 acre- $\mathrm{ft}$ ( 40 $\mathrm{hm}^{3}$ ) in 26 years.

\section{SOURCES OF GROUND-WATER DEGRADATION}

Figure 4 is a diagram of the system or cycle of water use in the project area. Some ground water recharged to the basin along the Mojave River is pumped upgradient from Barstow. After use by the city and other agencies, some of this water is returned to the ground-water system by percolation from the city's waste-disposal facilities. Water for irrigation in the area follows a similar pattern: that is, it is pumped, used, and some is returned to the ground-water body, except that the excess water available for percolation does not contain some of the chemical constituents that are added during domestic and industrial use. Water is used at the USMC Supply Center for a combination of industrial, domestic, and irrigation purposes similar to that upstream, only on a smaller scale.

Sources of impairment of ground-water quality in the Barstow area include: (1) Natural; (2) domestic- and industrial-waste disposal; and (3) irrigation return. Much of the historic information in the following discussion of sources of ground-water degradation was taken from a report by the California Department of Public Health and California Department of Water Resources (1960, p. 18-32).

\section{NATURAL}

Ground-water inflow from areas south of the river is generally high in dissolved solids. For modeling purposes, S. G. Robson (1974; Hughes and Robson, 1973) assumed inflow from the south to contain an average of about $1,000 \mathrm{mg} / \mathrm{l}$ (milligrams per litre) dissolved solids. Because the rate and volume of inflow associated with this source are comparatively low (table 2), the influence on the ground-water quality in the basin is small.

\section{INDUSTRIAL AND DOMESTIC WASTE CITY OF BARSTOW}

The city of Barstow has operated three sewagetreatment plants since 1938. Each plant has been located adjacent to or constructed on the river-channel 


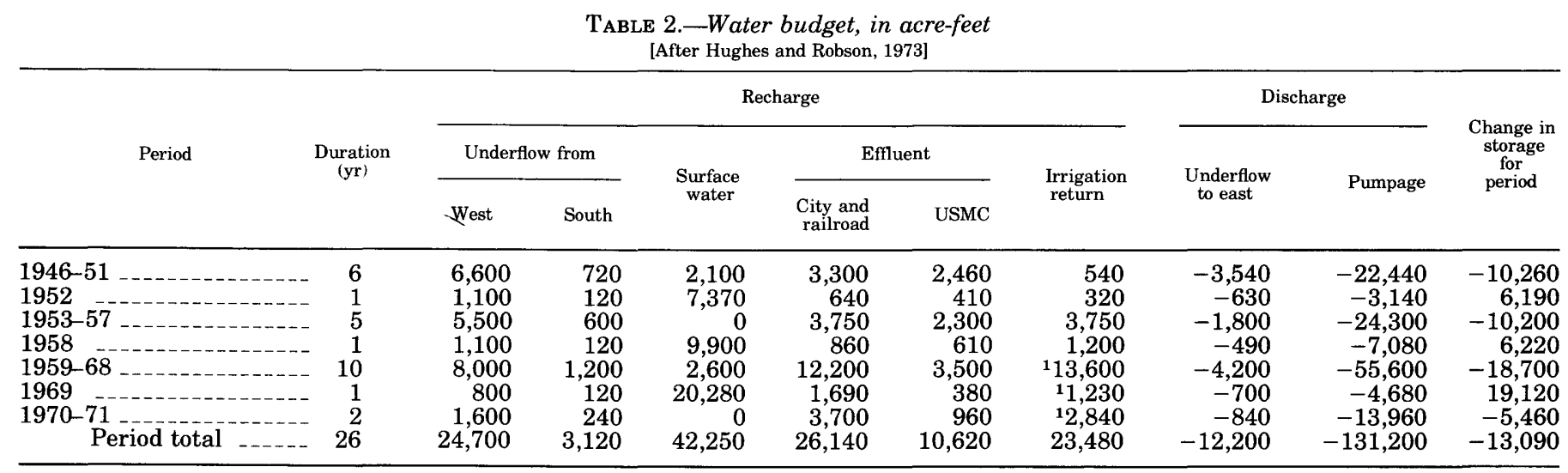

${ }^{1}$ Includes 150 acre-feet per year irrigation return from USMC golf course.

deposits of the Mojave River, and the city has used this medium for disposal of waste effluents. Effluent from the 1938 plant (site A, fig. 3) was discharged directly to the Mojave River bed. That facility reportedly handled only domestic wastes, with the exception of synthetic detergents and soaps from laundries after 1945.

In 1953 a new sewage-treatment plant (site B, fig. 3) was constructed about half a mile east and downstream from site A. This plant provided increased capacity and additional stages of treatment for handling the city's growing volume of sewage. The design capacity of the plant was $2.25 \mathrm{Mgal} / \mathrm{d}\left(1.8 \times 10^{10} \mathrm{~m}^{3} / \mathrm{d}\right)$ for primary treatment and $1.0 \mathrm{Mgal} / \mathrm{d}\left(7.9 \times 10^{9} \mathrm{~m}^{3} / \mathrm{d}\right)$ for secondary treatment. In 1965 the average daily flow was 1.2 $\mathrm{Mgal} / \mathrm{d}\left(9.4 \times 10^{9} \mathrm{~m}^{3} / \mathrm{d}\right)$; therefore $0.2 \mathrm{Mgal} / \mathrm{d}\left(1.6 \times 10^{9}\right.$ $\mathrm{m}^{3} / \mathrm{d}$ ) did not receive secondary treatment. Disposal of effluent from this facility was by direct percolation and evaporation from oxidation ponds. Some treated effluent was diverted for irrigation of alfalfa (fig. 4). The city of Barstow's effluent reportedly consisted only of treated domestic wastes with the possible exception of synthetic detergents and soaps from laundries. Prior to 1953 the Atchison, Topeka and Santa Fe (A.T. and S.F.) Railway treated and disposed of its domestic and industrial wastes, but with construction of the larger city plant, the company restricted its treatment to industrial wastes and discharged domestic wastes to the city sewer system.

The constant increase in volume of waste effluent associated with a growth of population and industry required a larger sewage-treatment facility, and in late 1968 a new treatment facility was built by the city of Barstow on a site a short distance upstream from the USMC Supply Center (site C fig. 3). At present (1972), the new facility provides primary treatment, with mechanical aeration in one pond and six additional oxidation ponds. The plant was modified to provide complete secondary treatment and became operational in March 1973 (Robert Beach, oral commun., city of Barstow, 1972).
Chemical analyses of waste from the city of Barstow's facilities (table 3) indicate that the effluent has been high in detergents (as MBAS), with concentrations ranging from 0.48 to $16 \mathrm{mg} / \mathrm{l}$. The average has been well above the limits set for discharge at this facility by the California Water Quality Control Board, Lahontan Region. The Board's maximum limits for detergents (as MBAS) in the effluent that percolates to the groundwater basin has been, at different times, $0.5 \mathrm{mg} / \mathrm{l}$ and 1.0 $\mathrm{mg} / \mathrm{l}$. The concentration of phenols in the Barstow effluent has been as high as $0.15 \mathrm{mg} / \mathrm{l}$. The Board's maximum limit for phenols is $0.002 \mathrm{mg} / \mathrm{l}$. The concentration of dissolved solids, chloride, and sodium has been marginal compared with their respective limits of 900,120 , and $160 \mathrm{mg} / \mathrm{l}$.

\section{ATCHISON, TOPEKA AND SANTA FE RAILWAY}

Available records of industrial waste discharge by the A.T. and S.F. Railway suggest that discharge began about 1910 with the construction of a drain system from the shop and yards to the Mojave River (site A, fig. 3). This waste effluent included fuel oils and solvents. In 1915 an oil trap was constructed so that the fuel oils could be separated from the water and reused. This facility was reportedly small and required retention time for separation of the oil, suggesting that during periods of peak loads, spills and direct discharge to the river probably occurred. With the exception of an attempt to absorb some of the oils passing the traps, this form of treatment did not change until 1952. Much of the need to modify industrial-waste handling by the railroad was caused by the conversion from steampowered to diesel-powered locomotives, which began in 1942 and was completed in 1952. With the advent of diesel engines came a need for coolants with corrosionpreventative compounds for use in radiators. An additive containing hexavalent chromium was used beginning about 1948. Until 1952 it was common practice to drain the radiator coolants into the waste-disposal system which discharges to the Mojave 


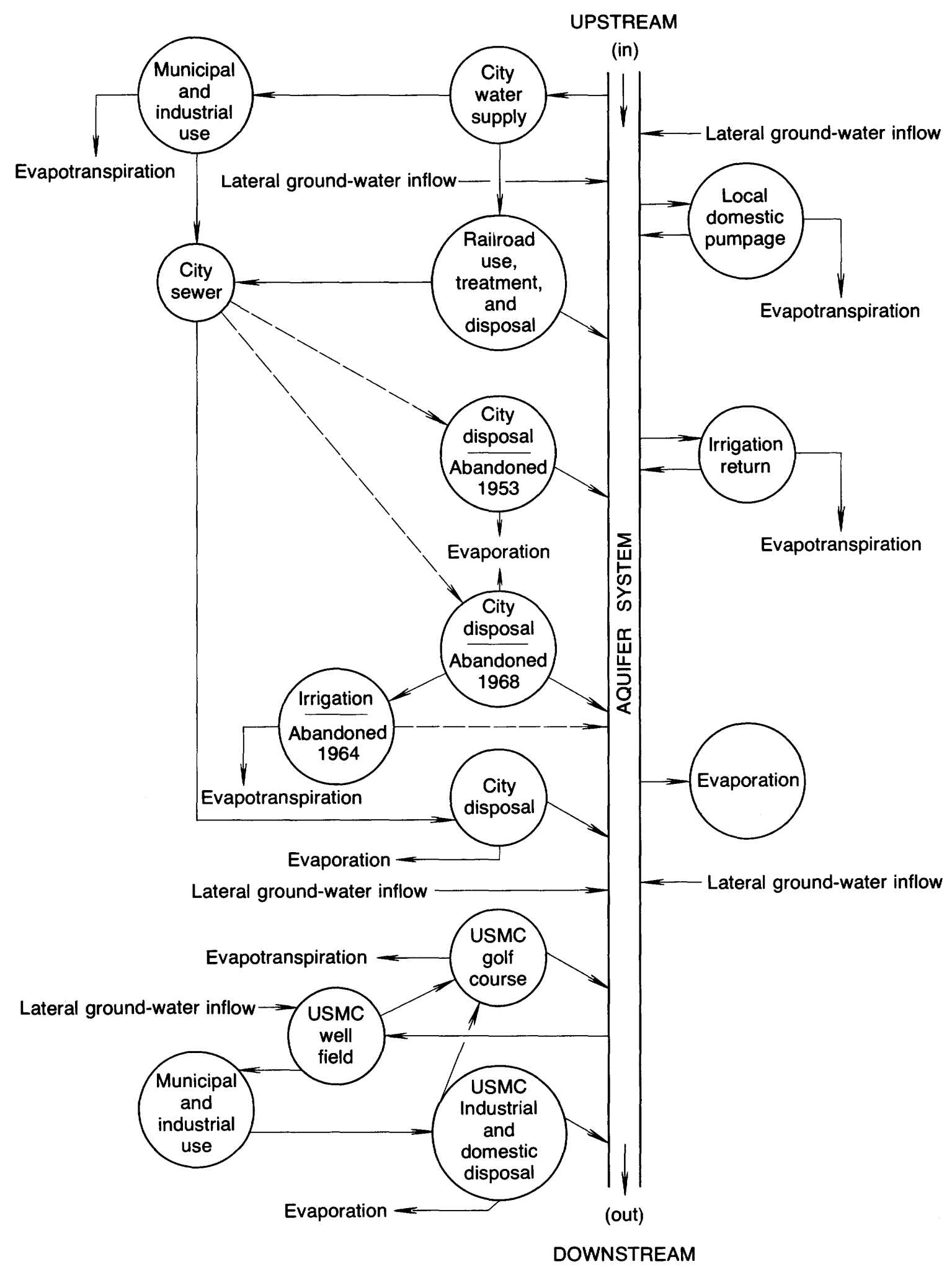

FiguRE 4.-Water use in project area.

River (California Department of Public Health and facility produced an effluent containing emulsified oil, California Department of Water Resources, 1960, p. 29).

A laundry was constructed in 1949 by the railroad to wash grease- and oil-saturated rags and clothing. This grease, synthetic detergents, and a disinfectant with a high concentration of phenolic compounds.

During 1954 and 1958, two dikes were constructed by 
TABLE 3.-Chemical analyses of the [Constituents in milligrams per litre, except total iron, boron, and arsenic in micrograms per litre;

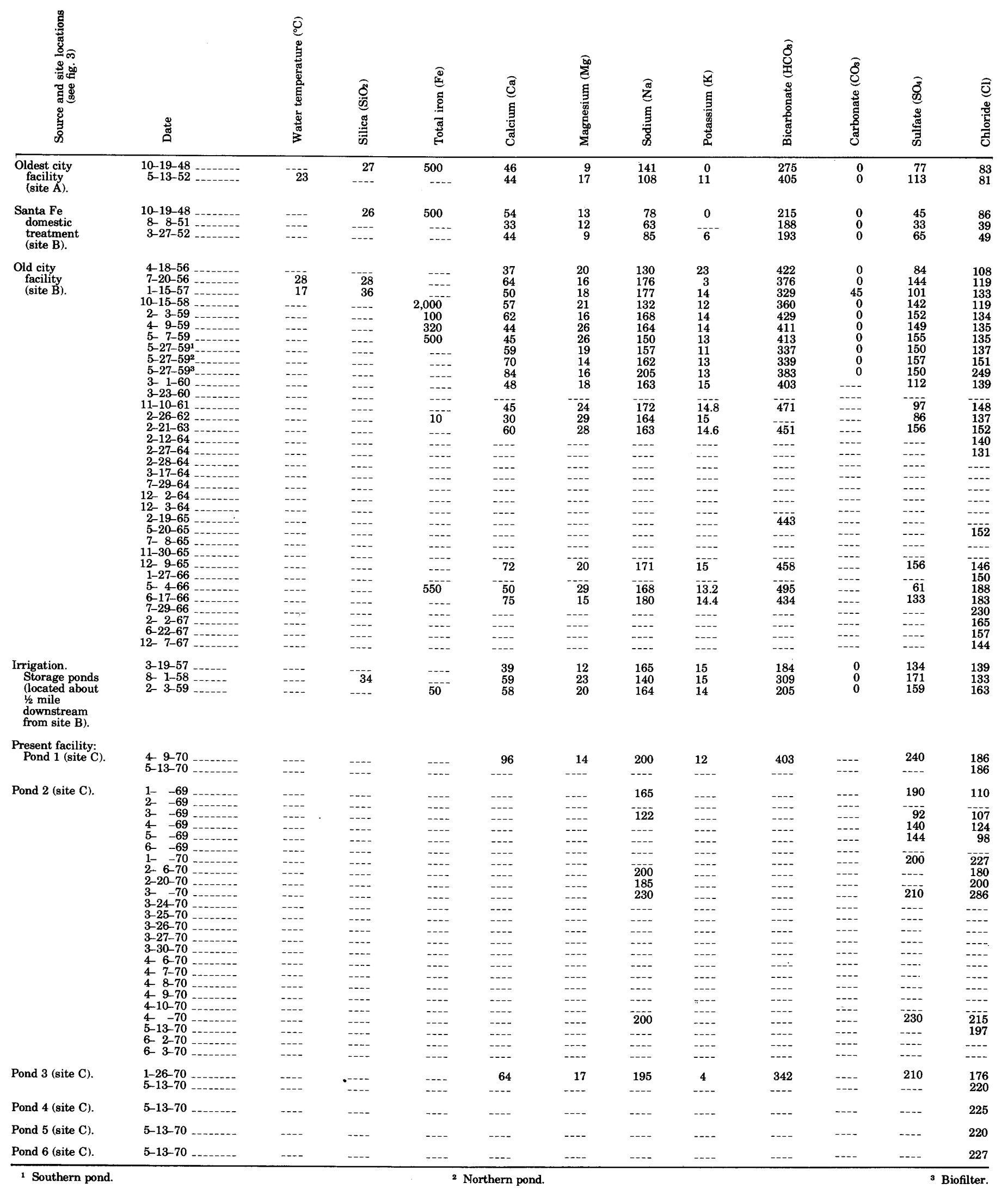


domestic wastes of the city of Barstow

water temperature in degrees Celsius; specific conductance in micromhos at $25^{\circ} \mathrm{C}$; and $\left.\mathrm{pH}\right]$

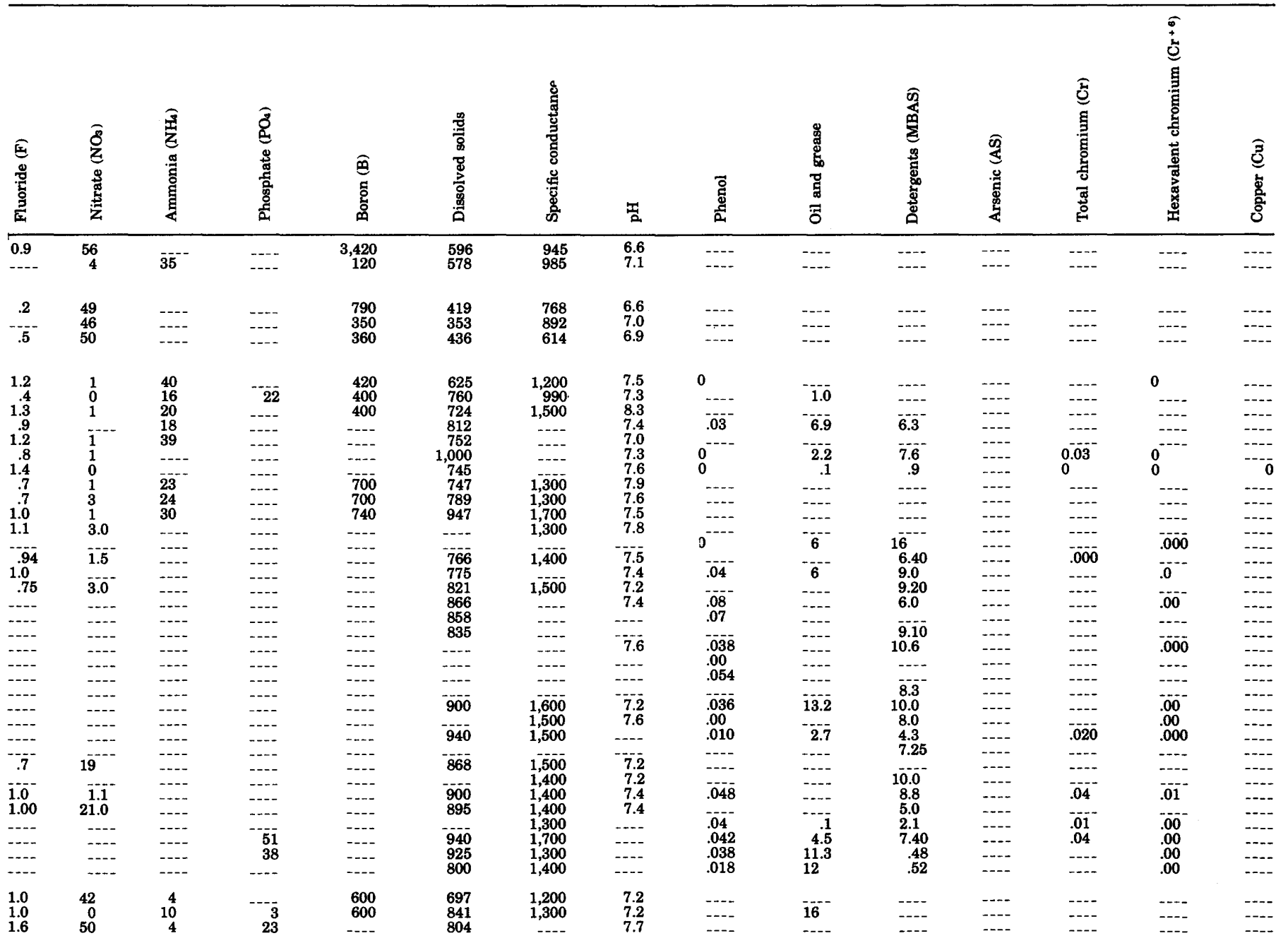

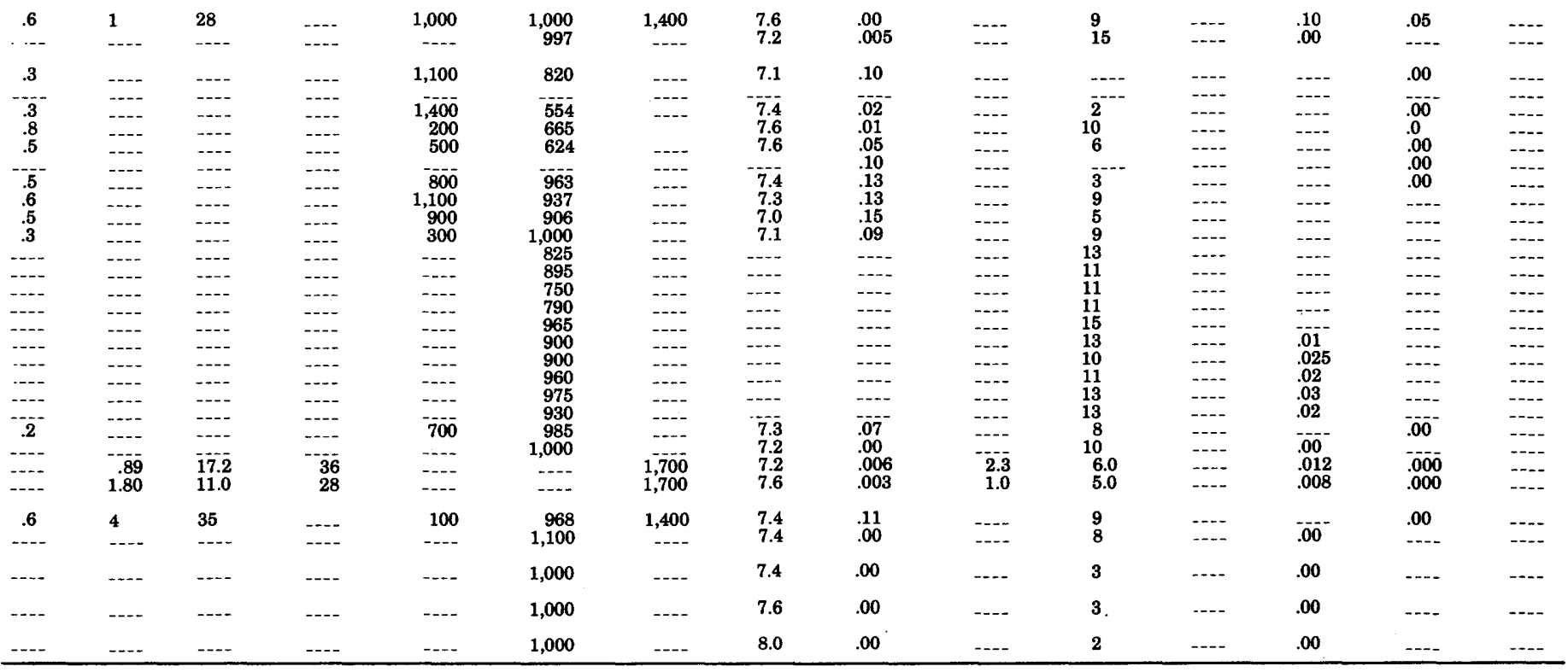


the railroad in the river (site A, fig. 3) to hold treated effluent. The diked areas provided for physical separation of oil and sludge but did not control the percolation of synthetic detergents, chromium, emulsified oils, and phenolic compounds. The dikes were constructed of river-channel sand, which offered little resistance to floods. Both dikes were destroyed by floods in April 1958 but were reconstructed during the summer of 1958 .

From 1959 to 1968 , the railroad installed facilities for flocculation, surface stripping, and oxidation of wastes. It also changed from the use of ABS to LAS (nonbiodegradable to biodegradable) synthetic detergents and abandoned its laundry and caustic cleaning vats at the diesel shop, thereby eliminating two sources of phenolic compounds from the waste effluent.

In 1968 the railroad modified the treatment of wastes to comply with the effluent standards established by the California Water Resources Control Board, Lahontan Region (resolution 66-18, 1966) and by the city of Barstow. Most railroad waste subsequently was exported to the new city waste-treatment facility (site C, fig. 3) by means of the city sewer system.

The chemical quality of waste from the facilities of the A.T. and S.F. Railway (table 4) has varied depending on the source, rate and volume of discharge, and sampling site. These variations are indicated in part by $\mathrm{pH}$ values, which range from very acidic, 3.9 , to very basic, 12.4. Comparison of concentrations in wastes for detergents $(0.35-64 \mathrm{mg} / \mathrm{l})$, phenols $(0.000-1.0 \mathrm{mg} / \mathrm{l})$, oil and grease $(0.04-4,000 \mathrm{mg} / \mathrm{l})$, chlorides $(34-496 \mathrm{mg} / \mathrm{l})$, boron $(0.06-46 \mathrm{mg} / \mathrm{l})$, sodium $(80-1,200 \mathrm{mg} / \mathrm{l})$, dissolved solids (311-2,700 mg/l), total chromium (0.00-4.80), and hexavalent chromium $(0.000-11 \mathrm{mg} / \mathrm{l})$, with requirements of the California Water Resources Control Board, Lahontan Region (resolution 66-18, 1966), indicates that at times concentrations far above published standards have been available for percolation to the ground-water system.

\section{U.S. MARINE CORPS SUPPLY CENTER, NEBO}

Facilities for treatment and disposal of industrial and domestic waste at the USMC Supply Center were built in 1942 (site E, fig. 3) and were subsequently modified and expanded in 1952 and 1957 . The present system provides primary treatment and some degree of secondary treatment. Disposal of treated effluent is by evaporation or by direct percolation to the Mojave River. Until late 1972 treated effluent was also used as irrigation water for a local golf course (site D, fig. 3). This method of disposal has since been discontinued. Some concentrated industrial-waste products are transferred to the USMC supply annex at Yermo (fig. 1) for disposal.

According to a report on the waste-treatment facilities at the USMC Supply Center (Brown and Caldwell, 1970), the plant is inadequate and difficult to operate, resulting in occasional spills and odors. Consideration is now being given to reconstructing and updating the facilities, or transferring all effluent to the city of Barstow for treatment and disposal.

Chemical analyses of waste discharged by the USMC Supply Center (table 5) indicate that the concentrations of oil and grease and phenols in the waste effluent have been as high as 79 and $0.06 \mathrm{mg} / \mathrm{l}$. As a result of influent industrial wastes, $\mathrm{pH}$ values in the effluent have ranged from 7.2 to 10.0 .

\section{MINING AND MILLING OPERATIONS}

Two mining and milling operations were active in the Barstow area until 1954-the PCMMC (Pacific Coast Milling and Mining Co.) and a tungsten mill. The PCMMC disposed of its industrial wastes in an area adjacent to a complex of wells now operated as the city's water supply (located about half a mile upstream from site A, not shown in fig. 3). Sparse records do not indicate the volumes of waste discharged, but they do indicate that the waste was high in iron, aluminum, copper, lead, calcium, magnesium, and sodium. The concentrations of dissolved solids in waste effluent were $2,300 \mathrm{mg} / \mathrm{l}$ and 3,200 mg/l in March and August 1952 (table 6).

Disposal of wash water from the tungsten mill was at the same location as the waste-disposal facility of the A.T. and S.F. Railway and the city's first disposal site A (fig. 3). Available chemical analyses indicate that for those substances analyzed (table 6), the waste water was apparently similar to the local ground water. The volume of waste was estimated to be 25-50 acre-ft $\left(30,000-60,000 \mathrm{~m}^{3}\right)$ per year.

\section{IRRIGATION RETURN}

The high rate of evapotranspiration in the Barstow area requires that large quantities of water be applied to crops. Alfalfa, the major crop in this area, transpires about $3 \mathrm{ft}(0.9 \mathrm{~m})$ of water per year (Meyer and Horn, 1955 , p. 197) when about 5-7 ft (1.5-2.1 m) of water per year is applied for irrigation. Allowing for consumptive use, leaching of minerals from the soils, and the solution of fertilizers, the concentration of dissolved solids in irrigation-return water could be at least doubled. Assuming that the applied irrigation water in the northeastern part of secs. 4 and 10, T. 9 N., R. 1 W. (fig. 3) contained $350-450 \mathrm{mg} / \mathrm{l}$ of dissolved solids, the irrigation-return water could contain more than 700 $\mathrm{mg} / \mathrm{l}$ of dissolved solids.

The annual volume of irrigation-return water (table 2) has been estimated to be (1) nearly equal to annual underflow into the Barstow area from the west, (2) 
greater than the average annual volume of domestic and industrial waste that percolated to the river from the city treatment facilities prior to 1952 , and (3) only slightly less than the average annual volume associated with the facilities operated from 1962 to 1968.

Until 1964, effluent from the city of Barstow treatment facility (site B, fig. 3) was used for irrigation of alfalfa at a site about half a mile downstream. That part of the effluent not required for irrigation was discharged by the city of Barstow to the Mojave River (California Department of Public Health and California Department of Water Resources, 1960, p. 24-26). This source of ground-water recharge is included with effluent-recharge data in table 2. Chemical analyses of water in storage ponds where effluent was retained prior to use for irrigation indicate that the water was acceptable for irrigating alfalfa. Chemical analyses for other than the major constituents were not available.

Effluent from the waste-water treatment facilities at the USMC Supply Center (site E, fig. 3) was used for irrigating a golf course (site D, fig. 3) between 1959 and 1972. The volume of effluent used annually varied only slightly and totaled about 4,000 acre-ft $\left(5 \mathrm{hm}^{3}\right)$ or approximately 300 acre-ft $\left(0.4 \mathrm{hm}^{3}\right)$ per year for 14 years. Most of the treated water was applied during the summer. Chemical analyses of the treated water indicated a concentration of dissolved solids of about $1,000 \mathrm{mg} / \mathrm{l}$ (table 5). The concentrations of most chemical constituents were within the generally accepted limits for irrigation. Because of the high consumptive use and the presence of sandy soils at the golf course, about half of the applied water returned to the aquifer, therefore, the concentration of dissolved solids in the return water is estimated to be $2,000 \mathrm{mg} / \mathrm{l}$.

Chemical analyses of the water from the USMC Supply Center oxidation pond (mixed effluent, table 5), which has been used for golf-course irrigation, indicate that the concentrations of most chemical constituents are generally within the acceptable limits recommended for percolation by the California Water Resources Control Board, Lahontan Region (resolution $66-18,1966)$. The concentration of phenols, oil and grease, fluoride, and detergents was occasionally above those limits.

\section{DISTRIBUTION AND EVALUATION OF CHEMICAL SUBSTANCES AFFECTING GROUND-WATER DEGRADATION}

Percolation of waste effluents from industrial and municipal sources, plus irrigation return, has seriously affected the quality of the ground water in the younger alluvial aquifer east of Barstow. The extent of the degraded ground water has been identified both areally and vertically by the concentration and distribution of dissolved solids, detergents (as MBAS), dissolved organic carbon, total nitrogen, and chloride.

The vertical sections (see figs. 6, 8-11) that are used to illustrate the distribution of selected chemical substances in ground water are based on chemical analyses of samples collected from March 27 to April 7, 1972. The patterns of distribution of the chemical constituents were drawn on the basis of chemical analyses of water from wells which are either on or near the trace of the vertical sections and reflect hydrologic stresses resulting from recharge and discharge in the aquifer.

Two planes of projection are used (see figs. 6, 8-11) to illustrate the vertical distribution of selected chemical substances in ground water-the longitudinal section which is more or less along the flow system, and the cross sections which are at right angles to the longitudinal section. The trace of the longitudinal section $A-A^{\prime}$ remains unchanged for each of the chemical substances discussed. The cross sections are shown at three different locations $\left(B-B^{\prime}, C-C^{\prime}\right.$, and $\left.D-D^{\prime}\right)$ to better illustrate conditions related to variations in types and methods of waste disposal.

The patterns of distribution of chemical substances suggest a certain uniformity of occurrence and flow within the hydrologic system. However, monthly sampling of three test wells, $9 \mathrm{~N} / 1 \mathrm{~W}-9 \mathrm{H} 5,-9 \mathrm{H} 7$, and $-10 \mathrm{~J} 3$, indicates that the distribution of chemical constituents in the ground water is changing with time, particularly in the deeper zone. Such changes in ground-water quality with time are to be expected because of the movement of fluids in the aquifer, and because the quality and the quantity of wastes discharged to the ground-water system have varied in time. Figure 5 illustrates the changes in selected chemical constituents in the ground water in these wells with time; the changes are based on the samples of water and resultant analyses.

Maps showing the areal distribution of water quality in an aquifer system are often misleading because they generally do not show variations in chemical concentrations with depth. In this report, maps showing the areal distribution of various constituents are used only to illustrate, for discussion purposes, those areas degraded by a selected minimum concentration of a chemical substance.

Some similarities in the distribution of general chemical quality are apparent in each of the sections in figures $6,8-11$. Along section $A-A^{\prime}$ data indicate a general increase in constituent concentration with depth upstream from well 9N/1W-9B1. This increase has resulted from large volumes of floodwater containing low dissolved solids that has moved downward from the stream channel into the aquifer and depressed the poorer quality water that had previously percolated to 
TABLE 4.-Chemical analyses of the industrial wastes [Constituents in milligrams per litre, except total ıron, boron, and arsenic in micrograms per litre;

\begin{tabular}{|c|c|c|c|c|c|c|c|c|c|c|c|c|c|}
\hline 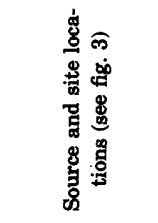 & 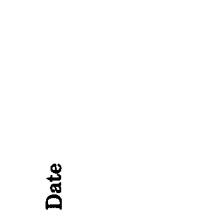 & 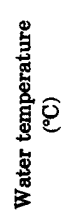 & 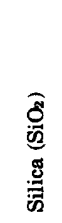 & 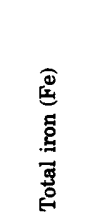 & 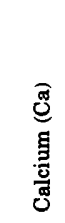 & 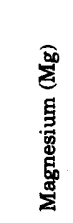 & 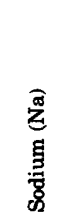 & $\begin{array}{l}\overline{8} \\
\text { 蒠 } \\
\text { 兽 }\end{array}$ & 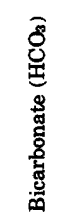 & 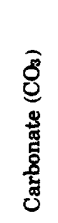 & 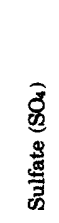 & 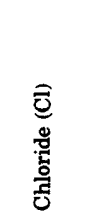 & 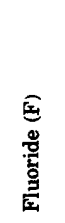 \\
\hline $\begin{array}{l}\text { Ditch. } \\
\text { Shops and } \\
\text { yards } \\
\text { (site A). }\end{array}$ & 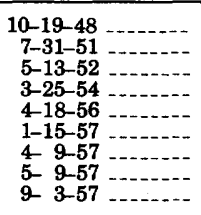 & $\begin{array}{c}0 \\
\cdots \\
\cdots \\
17 \\
20 \\
20 \\
\cdots\end{array}$ & $\begin{array}{l}51 \\
2.0 \\
-. .0 \\
-.0 \\
41 \\
26 \\
-\cdots\end{array}$ & $\begin{array}{r}300 \\
2,400 \\
\cdots-. \\
\cdots-. \\
\cdots-. \\
\cdots-. \\
\cdots-.\end{array}$ & $\begin{array}{r}36 \\
72 \\
-44 \\
38 \\
58 \\
57 \\
-\ldots \\
-\cdots\end{array}$ & $\begin{array}{c}10 \\
11 \\
5 \\
10 \\
12 \\
13 \\
\cdots \\
\cdots\end{array}$ & \begin{aligned} 133 \\
98 \\
-980 \\
-894 \\
294 \\
87 \\
87 \\
\hdashline--\end{aligned} & \begin{tabular}{c}
6 \\
-7 \\
11 \\
35 \\
5 \\
\hdashline-
\end{tabular} & $\begin{array}{l}361 \\
260 \\
-183 \\
339 \\
323 \\
265 \\
268 \\
253\end{array}$ & 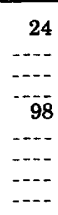 & $\begin{array}{r}64 \\
12 \\
-75 \\
-794 \\
300 \\
91 \\
9-0\end{array}$ & $\begin{array}{r}34 \\
154 \\
55 \\
73 \\
100 \\
55 \\
65 \\
51\end{array}$ & $\begin{array}{l}0.7 \\
.4 \\
-. .3 \\
1.3 \\
1.25 \\
.75 \\
\cdots-. \\
-.-\end{array}$ \\
\hline $\begin{array}{l}\text { Ditch. } \\
\text { Stockyards } \\
\text { (site A). }\end{array}$ & 4-18-56 & 18 & .... & -..- & $-\cdots$ & $\ldots$ & --- & --- & 246 & $\ldots$ & --. & 72 & $\cdots$ \\
\hline \multirow[t]{25}{*}{$\begin{array}{l}\text { Percolation } \\
\text { pond. Main } \\
\text { shop treated } \\
\text { effiuent) } \\
\text { (site A). }\end{array}$} & 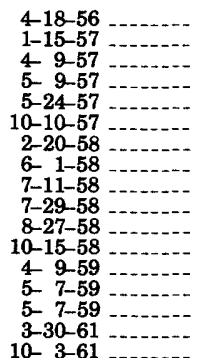 & 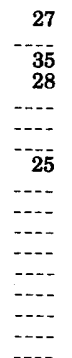 & 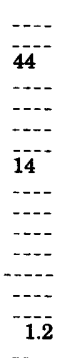 & $\begin{array}{c}\cdots-. \\
\cdots-. \\
\cdots-- \\
\cdots-. \\
\cdots-. \\
\cdots-. \\
\cdots-. \\
1,600 \\
1,000 \\
2,000 \\
0 \\
\cdots\end{array}$ & $\begin{array}{c}22 \\
17 \\
14 \\
\cdots-- \\
\cdots-. \\
-14 \\
-25 \\
-25 \\
-25 \\
24 \\
22 \\
5 \\
47\end{array}$ & $\begin{array}{l}\mathbf{5} \\
\mathbf{6} \\
\mathbf{5} \\
-\cdots- \\
-\cdots- \\
-9- \\
\mathbf{9} \\
7 \\
7-- \\
12 \\
5 \\
7 \\
2 \\
8.5\end{array}$ & \begin{tabular}{l}
360 \\
345 \\
545 \\
$-\ldots$ \\
\hdashline$\cdots$ \\
-16 \\
267 \\
278 \\
2382 \\
2270 \\
370 \\
310 \\
256
\end{tabular} & \begin{tabular}{l}
13 \\
16 \\
12 \\
$\cdots--$ \\
\hdashline-- \\
-17 \\
-18 \\
-120 \\
20 \\
22 \\
25 \\
11
\end{tabular} & $\begin{array}{l}142 \\
381 \\
153 \\
226 \\
550 \\
375 \\
342 \\
348 \\
375 \\
364 \\
322 \\
343 \\
343 \\
360 \\
171 \\
167\end{array}$ & $\begin{array}{r}254 \\
60 \\
498 \\
99 \\
10 \\
1131 \\
52 \\
53 \\
86 \\
62 \\
76 \\
36 \\
44 \\
156 \\
202\end{array}$ & $\begin{array}{l}198 \\
236 \\
180 \\
\cdots- \\
\cdots-- \\
199 \\
-198 \\
192 \\
190 \\
238 \\
193 \\
420\end{array}$ & $\begin{array}{r}84 \\
103 \\
70 \\
80 \\
73 \\
64 \\
81 \\
90 \\
78 \\
80 \\
93 \\
84 \\
80 \\
82 \\
95 \\
56\end{array}$ & $\begin{array}{l}1.2 \\
1.25 \\
.8 \\
\cdots-. \\
\cdots-. \\
-.4 \\
1.0 \\
1.0 \\
-.6- \\
1.0 \\
1.2 \\
1.4 \\
.5\end{array}$ \\
\hline & 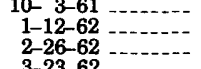 & $\cdots$ & $\cdots$ & $\begin{array}{l}\cdots \\
\cdots \cdots \\
\cdots-\end{array}$ & $-3 \overline{1}$ & 6 & 220 & 11 & $7 \overline{3}$ & $\cdots$ & 399 & 60 & .38 \\
\hline & $\begin{array}{l}\overline{3}-23-62 \\
4-462 \\
4-16-62\end{array}$ & $\cdots$ & $\cdots$ & $\cdots$ & $\cdots$ & $\cdots$ & $\cdots$ & $\cdots$ & $\cdots$ & $\cdots$ & $\cdots$ & $\cdots$ & $\cdots$ \\
\hline & $\begin{array}{l}4-16-62 \\
5-62 \\
5-28-62 \\
5---\cdots-\end{array}$ & $\cdots$ & $\cdots$ & $\cdots$ & $\cdots$ & $\cdots$ & $\cdots$ & $\cdots$ & 171 & $\cdots$ & $\cdots$ & 104 & $\cdots$ \\
\hline & $\begin{array}{l}0-31-62 \\
5-36-\cdots \\
6-6-62\end{array}$ & $\cdots$ & $\cdots$ & $\cdots$ & $\cdots$ & $\cdots$ & $\cdots$ & $\cdots$ & $\cdots$ & $\cdots$ & $\cdots$ & 135 & $\cdots$ \\
\hline & $\begin{array}{l}7-26-62 \\
9-20-62\end{array}$ & -..- & $\cdots$ & $\cdots$ & -60 & 16 & 304 & 17.1 & $\begin{array}{l}118 \\
129\end{array}$ & $\cdots$ & 512 & $169^{9.7}$ & 0 \\
\hline & $\begin{array}{l}9-20-62 \\
9-20-62\end{array}$ & $\cdots$ & $\cdots$ & 180 & 78 & 20 & 280 & 31 & 107 & $\cdots$ & $\cdots$ & 308 & \\
\hline & $\begin{array}{l}10-31-62 \\
12-18-62\end{array}$ & $\cdots$ & $\cdots$ & -... & $\cdots$ & $\cdots$ & $\cdots$ & $\cdots$ & $\begin{array}{l}107 \\
115\end{array}$ & $\cdots$ & $\cdots$ & $\begin{array}{l}308 \\
274\end{array}$ & $\cdots$ \\
\hline & $\begin{array}{r}12-18-62 \\
2-7-63\end{array}$ & $\ldots$ & $\cdots$ & $\cdots$ & $\cdots$ & $\cdots$ & $\cdots$ & $\cdots$ & 89 & $\cdots$ & $\cdots$ & 325 & $\cdots$ \\
\hline & $\begin{array}{l}2-21-63 \\
3-8-63\end{array}$ & $\cdots$ & $\cdots$ & $\cdots$ & $5 i$ & $17^{--}$ & 305 & 14.8 & $\begin{array}{l}220 \\
209\end{array}$ & $\cdots$ & 413 & 185 & .27 \\
\hline & $\begin{array}{l}3-20-63 \\
5-14-63\end{array}$ & $\cdots$ & $\cdots$ & 420 & $6 \overline{3}$ & 18 & $\overline{314}$ & 40 & 198 & $\cdots$ & $\cdots$ & 143 & $\cdots$ \\
\hline & $\begin{array}{r}7-19-63 \\
7-26-63\end{array}$ & -.. & $\cdots$ & $\cdots$ & $\cdots$ & $\cdots$ & $\cdots$ & $\cdots$ & 154 & $\cdots$ & $\cdots$ & $\cdots$ & $\cdots$ \\
\hline & $\begin{array}{l}10-863 \\
11-12-63\end{array}$ & $\cdots$ & $\cdots$ & 90 & 84 & 27 & $-\overline{15} \overline{1}$ & 43 & 136 & $\cdots$ & $\cdots$ & 308 & $\cdots$ \\
\hline & $\begin{array}{l}2-12-64 \\
2-27-64\end{array}$ & $\cdots$ & $\cdots$ & $\cdots$ & -- & $\cdots$ & $\cdots$ & $\cdots$ & $\cdots$ & $\cdots$ & $\cdots$ & 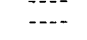 & $\cdots$ \\
\hline & $\begin{array}{l}3-17-64 \\
5-20-64\end{array}$ & $\cdots$ & $\cdots$ & -480 & 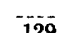 & -34 & & 28 & $\cdots$ & -.-- & $\cdots$ & -..- & $\cdots$ \\
\hline & $\begin{array}{l}0-14-64 \\
6-1 \\
7-29-64\end{array}$ & $\cdots$ & $\cdots$ & -... & 88 & $18^{-34}$ & 264 & 8.0 & $8 \overline{1}$ & $\cdots$ & 527 & 172 & .5 \\
\hline & $\begin{array}{l}11-12-64-\cdots \\
12-2-64\end{array}$ & $\cdots$ & $\cdots$ & $-8 \overline{8}$ & 76 & $19^{---}$ & 340 & 13.0 & $\cdots$ & $\cdots$ & $\cdots$ & $-\cdots$ & $\cdots$ \\
\hline & $\begin{array}{l}12-3-64 \\
12-20-65\end{array}$ & $\cdots$ & $\cdots$ & $\cdots$ & $\cdots$ & $\cdots$ & $\cdots$ & $\cdots$ & $\cdots$ & $\cdots$ & $\cdots$ & 236 & $\cdots$ \\
\hline & $\begin{array}{l}2-19-65 \\
3-65\end{array}$ & $\cdots$ & $\cdots$ & $\cdots$ & $\cdots$ & $\cdots$ & $\cdots$ & $\cdots$ & $\begin{array}{l}289 \\
308\end{array}$ & $\ldots$ & $\cdots$ & 445 & $\cdots$ \\
\hline & 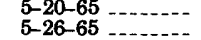 & $\cdots$ & $\ldots$ & -..- & $\cdots$ & $\cdots$ & $\cdots$ & $\cdots$ & 194 & $\cdots$ & $\cdots$ & $\begin{array}{l}278 \\
496\end{array}$ & $\ldots$ \\
\hline & $\begin{array}{l}7-82-65 \\
9-22-65\end{array}$ & $\cdots$ & $\cdots$ & $\cdots$ & $\cdots$ & $\cdots$ & $\cdots$ & $\cdots$ & 209 & $\cdots$ & $\cdots$ & 393 & $\cdots$ \\
\hline & & & $\ldots$ & $\cdots$ & 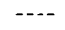 & $\cdots$ & $\cdots$ & $\cdots$ & $\cdots$ & 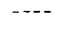 & $\ldots$ & 216 & 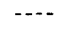 \\
\hline & $\cdots$ & $\cdots$ & $\cdots$ & 750 & 70 & 17 & 356 & 9.8 & 285 & $\cdots$ & 464 & 226 & .4 \\
\hline & $\cdots$ & 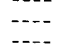 & & $\cdots$ & $\cdots$ & $\cdots$ & $\cdots$ & $\cdots$ & $\cdots$ & $\cdots$ & $\cdots$ & $\begin{array}{l}282 \\
339\end{array}$ & $\cdots$ \\
\hline & $12-7-67=-$ & -- & & --.- & & $\cdots$ & $\cdots$ & $\cdots-$ & $\cdots$ & $\ldots$ & $\cdots$ & $\begin{array}{l}298 \\
298\end{array}$ & $\cdots-$ \\
\hline \multirow{5}{*}{$\begin{array}{l}\text { Ditch. Main } \\
\text { shop and } \\
\text { skim pit } \\
\text { overfllow } \\
\text { (site A). }\end{array}$} & $\begin{array}{r}7-31-51 \\
11-30-51 \\
15\end{array}$ & $-\overline{38}$ & $\begin{array}{l}230 \\
133\end{array}$ & $\begin{array}{r}8,500 \\
18,000\end{array}$ & $\begin{array}{l}18 \\
19\end{array}$ & $\begin{array}{r}31 \\
4\end{array}$ & $\begin{array}{l}\mathbf{5 5 0} \\
{ }_{590}\end{array}$ & $\begin{array}{l}13 \\
21\end{array}$ & $\begin{array}{r}216 \\
0\end{array}$ & $\begin{array}{l}559 \\
401\end{array}$ & $\begin{array}{r}145 \\
41\end{array}$ & $\begin{array}{r}80 \\
100\end{array}$ & $\begin{array}{l}4.0 \\
4.4\end{array}$ \\
\hline & $\begin{array}{l}8-14522 \\
8-1452^{2}-\ldots\end{array}$ & $\begin{array}{l}38 \\
38\end{array}$ & $\cdots$ & $\cdots$ & $\cdots$ & $\cdots$ & $\cdots$ & $\cdots$ & $\cdots$ & $\cdots$ & $\cdots$ & $\cdots$ & 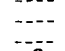 \\
\hline & $\begin{array}{l}3-25-54 \\
11-15-55\end{array}$ & $\cdots$ & $\cdots$ & 200 & 4 & 0 & 168 & 6 & 226 & 209 & $\ldots$ & $\begin{array}{l}124 \\
75\end{array}$ & .3 \\
\hline & $\begin{array}{l}1-15-57 \\
418-57 \\
5-24-1-\end{array}$ & $\begin{array}{l}22 \\
17\end{array}$ & $\begin{array}{l}1 \\
\cdots\end{array}$ & $\cdots$ & $\begin{array}{l}41 \\
45\end{array}$ & $\begin{array}{l}10 \\
13\end{array}$ & $\begin{array}{l}308 \\
230\end{array}$ & $\begin{array}{l}36 \\
12\end{array}$ & $\begin{array}{l}342 \\
315\end{array}$ & $\begin{array}{l}30 \\
53\end{array}$ & $\begin{array}{l}334 \\
182\end{array}$ & $\begin{array}{l}118 \\
84 \\
56\end{array}$ & $\begin{array}{l}1.25 \\
1.1\end{array}$ \\
\hline & $\begin{array}{r}10-10-57 \\
7-11-58 \\
-\end{array}$ & $\cdots$ & $\cdots$ & $\cdots$ & $\cdots$ & - & $\cdots$ & $\cdots$ & $\begin{array}{l}292 \\
408\end{array}$ & $\begin{array}{r}58 \\
246\end{array}$ & $\cdots$ & $\begin{array}{l}54 \\
83\end{array}$ & $\cdots$ \\
\hline
\end{tabular}


of the Atchison, Topeka and Santa Fe Railway

water temperature in degrees Celsius; specific conductance in micromhos at $25^{\circ} \mathrm{C}$; and $\mathrm{pH}$

\begin{tabular}{|c|c|c|c|c|c|c|c|c|c|c|c|c|c|}
\hline 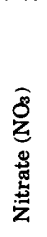 & 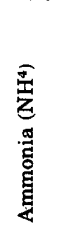 & 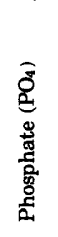 & 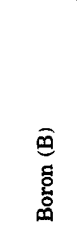 & 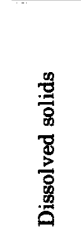 & 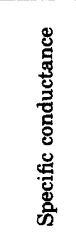 & 氶 & $\begin{array}{l}\overrightarrow{\mathrm{d}} \\
\stackrel{\vec{d}}{\mathbb{d}}\end{array}$ & 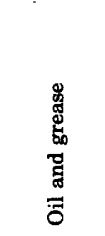 & 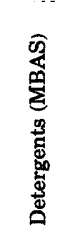 & 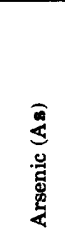 & 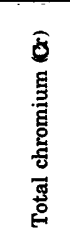 & 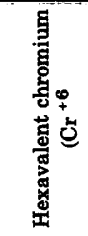 & $\begin{array}{l}\widehat{B} \\
\text { 总 } \\
\text { 总 }\end{array}$ \\
\hline $\begin{array}{l}0 \\
1\end{array}$ & -..- & -..- & $\begin{array}{l}1,390 \\
3,900\end{array}$ & $\begin{array}{l}634 \\
491\end{array}$ & $\begin{array}{l}780 \\
924\end{array}$ & $\begin{array}{l}8.8 \\
8.0\end{array}$ & …- & $\ldots$ & - & 5 & $0^{---}$ & $\cdots$ & $0^{--}$ \\
\hline 1 & $\cdots$ & $\cdots$ & 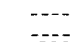 & 450 & $\cdots$ & 7.2 & $\begin{array}{r}0.86 \\
.04\end{array}$ & $740^{----}$ & --- & ...- & -..- & $\cdots$ & $-\cdots$ \\
\hline $\begin{array}{l}1 \\
1\end{array}$ & $\cdots$ & 4.0 & 200 & $\begin{array}{l}400 \\
995\end{array}$ & 1,400 & $\begin{array}{l}.2 \\
9.7\end{array}$ & $\begin{array}{l}.04 \\
.10\end{array}$ & $\begin{array}{r}140 \\
698\end{array}$ & - & -.-- & - & $0^{----}$ & $\cdots$ \\
\hline $\begin{array}{l}2 \\
0\end{array}$ & $\cdots$ & $\cdots$ & $\begin{array}{l}200 \\
420\end{array}$ & $\begin{array}{l}980 \\
530\end{array}$ & 1,600 & 7.7 & .38 & 3,500 & --. & $\cdots$ & $\cdots$ & --- & $\cdots$ \\
\hline$\ldots$ & $\ldots$ & $\cdots$ & -... & $\ldots$ & $\begin{array}{l}800 \\
785\end{array}$ & 7.5 & $\cdots$ & $\begin{array}{l}15 \\
20\end{array}$ & $\cdots$ & $\cdots$ & $\cdots$ & $\cdots$ & $\cdots$ \\
\hline$\cdots$ & $\cdots$ & $\cdots$ & $\cdots$ & $\cdots$ & 660 & 8.1 & $0^{-}$ & 4,000 & $\cdots$ & 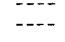 & - & $\cdots$ & $\cdots$ \\
\hline$\cdots$ & -..- & --- & -... & --- & 904 & 7.8 & -.-- & -..- & .... & $\ldots$ & -... & $\ldots$ & -..- \\
\hline$\frac{1}{2}$ & $-\cdots$ & --.- & 680 & 1,200 & 1,700 & 10.6 & .20 & 178 & $\ldots$ & -..- & --.- & .8 & -... \\
\hline $\begin{array}{l}2 \\
0\end{array}$ & - & $\begin{array}{l}\cdots-- \\
\cdots-.\end{array}$ & 2,000 & $\begin{array}{l}1,100 \\
1,500\end{array}$ & $\begin{array}{l}1,500 \\
2,100\end{array}$ & $\begin{array}{l}8.9 \\
9.8\end{array}$ & .25 & $\begin{array}{r}95 \\
2,800\end{array}$ &.--- & --- & -..- & -a- & $\begin{array}{l}---- \\
---\end{array}$ \\
\hline --.- & ---- & $\ldots$ & $\ldots$ & & 1,300 & 9.2 & $\cdots$ & 33 & 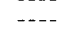 & 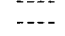 & $\cdots$ & $\ldots$ & $\ldots$ \\
\hline$\cdots$ & $\cdots$ & $\cdots$ & --- & $\begin{array}{l}1,200 \\
1500\end{array}$ & -.-- & $\begin{array}{l}8.3 \\
97\end{array}$ & --- & 56 & $\cdots$ & $--\cdot$ & $\cdots$ & .01 & $\cdots$ \\
\hline - & $\cdots$ & 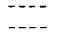 & $\cdots$ & $\begin{array}{l}1,080 \\
889\end{array}$ & $\cdots$ & 8.2 & 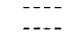 & 焉 & $\cdots$ & $\ldots$ & $\cdots$ & 0 & $\cdots$ \\
\hline 1 & $\cdots-$ & 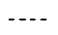 & 620 & 898 & 1,300 & 8.9 & 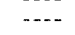 & 22 & $\cdots$ & $\cdots$ & $\cdots$ & -... & $\cdots$ \\
\hline 1 & $-\cdots$ & $\cdots$ & 420 & $\begin{array}{r}1,100 \\
978\end{array}$ & 1,300 & $\begin{array}{l}9.4 \\
8.8\end{array}$ & .9 & $\begin{array}{c}73.6 \\
180\end{array}$ & $\cdots$ & -..- & -..- & $\cdots$ & $\cdots$ \\
\hline 0 & $\cdots$ & $\cdots$ & --- & $\begin{array}{l}948 \\
896\end{array}$ & $\cdots$ & $\begin{array}{l}9.6 \\
8.8\end{array}$ & 02 & $\begin{array}{l}40.0 \\
20.4\end{array}$ & 11.5 & $\cdots$ & $\cdots$ & $\cdots$ & $-\cdots$ \\
\hline & $\cdots$ & $\cdots$ & 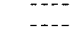 & 1,100 & 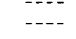 & 9.4 & 0 & 87.6 & 6.0 & -... & .68 & .24 & \\
\hline 0 & 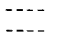 & 1.6 & 480 & $\begin{array}{l}1,100 \\
1,100\end{array}$ & 1500 & $\begin{array}{l}8.8 \\
9.5\end{array}$ & .40 & 53.8 & 1.3 & $\cdots$ & 2.66 & 2.50 & 0 \\
\hline $\begin{array}{l}1 \\
0\end{array}$ & $-\cdots$ & $\ldots$ & $\begin{array}{r}400 \\
---\end{array}$ & 918 & $\begin{array}{l}1,000 \\
1,300\end{array}$ & 7.1 & $.00^{-}$ & .2 & 5.0 & ... & $\begin{array}{r}4.80 \\
.08\end{array}$ & $\begin{array}{l}2.5 \\
.00\end{array}$ & 0 \\
\hline $2 . \overline{5}$ & $\cdots$ & $\cdots$ & $\cdots$ & 1,100 & 880 & 6.6 & .00 & 9.0 & 4.8 & $\cdots$ & -.- & .00 & ---- \\
\hline & & $\ldots$ & $-\ldots$ & $\ldots$ & $\ldots$ & $\begin{array}{l}0.0 \\
-\ldots .\end{array}$ & .03 & 26 & $\begin{array}{l}16 \\
17.2\end{array}$ & $\ldots$ & $\cdots$ & .00 & $\cdots$ \\
\hline$\cdots$ & $\cdots$ & $\cdots$ & $\cdots$ & ..... & $\cdots$ & $\cdots$ & $\ldots$ & 18 & 21 & -... & -- & .00 & -..- \\
\hline$\cdots$ & $-\cdots$ & $\cdots$ & $-\cdots$ & $-\overline{-}$ & 1,000 & $-\cdots$ & .08 & 22 & $\begin{array}{l}21 \\
17.5\end{array}$ & $\ldots$ & $\cdots$ & .00 & $\cdots$ \\
\hline$\cdots$ & --- & - & $\cdots$ & $\cdots$ & $\ldots$ & 6.7 & .115 & 19.2 & $\ldots$ & $\cdots$ & .00 & .00 & - \\
\hline$\cdots$ & 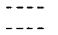 & $\cdots$ & $\cdots$ & $\ldots$ & 1,600 & 7.1 & $.06-$ & $\begin{array}{l}7.0 \\
4.7\end{array}$ & $\begin{array}{l}14 \\
9.8\end{array}$ & $\cdots$ & $\cdots$ & $\cdots$ & $\cdots$ \\
\hline$\cdots$ & $-\cdots-$ & ---- & -- & 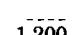 & -- & 68 & 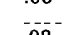 & 9.5 & 12.9 & - & $\ldots$ & - & -..- \\
\hline 0 & $\cdots$ & $\cdots$ & $\cdots$ & 1,200 & 1200 & 6.8 & .03 & $\begin{array}{l}7.2 \\
7.2\end{array}$ & $\begin{array}{l}3.0 \\
2.52\end{array}$ & $\cdots$ & $\cdots$ & .00 & .... \\
\hline --- & - & $\ldots$ & ---- & $\cdots$ & 1,200 & -1 & .01 & 13 & 11 & --.- & $\cdots$ & $0^{.00}$ & $\cdots$ \\
\hline$\cdots$ & $\cdots$ & .... & -... & --- & 1,300 & 8.4 & & & & ---- & -..- & & \\
\hline$\cdots-$ & $\cdots$ & $\cdots$ & $\cdots$ & 1200 & 1,200 & 80 & .15 & 5.6 & 3.6 & $\cdots$ & $-\cdots$ & .00 & $\cdots$ \\
\hline$\cdots$ & $\cdots$ & . & $\cdots$ & $\begin{array}{l}1,200 \\
1,200\end{array}$ & 1,900 & $\begin{array}{l}0.0 \\
7.0\end{array}$ & .08 & $\begin{array}{l}2.1 \\
17.6\end{array}$ & $\begin{array}{l}6.1 \\
3.12\end{array}$ & $\cdots$ & $\cdots$ & .00 & 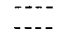 \\
\hline 2.5 & 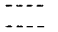 & $\cdots$ & $\cdots$ & 1,200 & 1700 & 70 & 1.0 & 16.0 & 14.0 & $\cdots$ & $\ldots$ & .03 & $\cdots$ \\
\hline$\cdots$ & $\cdots$ & $\cdots$ & $\cdots$ & 1,500 & 1,100 & 7.1 & .55 & 20.0 & 6.8 & $\ldots$ & - & $.00^{\circ}$ & .... \\
\hline$\cdots$ & --- & --- & --- & 1,100 & 1,700 & $\cdots$ & .05 & 34.0 & 21 & $\cdots$ & $17^{-}$ & .00 & $\cdots$ \\
\hline 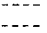 & $\cdots$ & --- & $-\cdots$ & $\cdots$ & $\cdots$ & 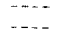 & .04 & $\begin{array}{r}8.6 \\
143\end{array}$ & 180 & $\cdots$ & .17 & . .00 & $\cdots$ \\
\hline$\ldots$ & $\ldots$ & - & - & 1,400 & - & 6.8 & .00 & .8 & 14.6 & $\ldots$ & $\cdots$ & $.00^{\circ}$ & $\cdots$ \\
\hline --.- & $\cdots$ & ...- & $\ldots$ & 1,200 & $\cdots$ & 6.9 & .05 & 4.8 & 11.1 & -..- & $\ldots$ & .00 & $\ldots$ \\
\hline$\cdots$ & $\cdots$ & $\cdots$ & --- & $\cdots-$ & $\cdots$ & $\cdots$ & .04 & 3.3 & 11.2 & $\cdots$ & $\cdots$ & 74 & $\cdots$ \\
\hline$\ldots$ & $\ldots$ & - & - & $\cdots$ & - & $\ldots$ & .03 & 3.0 & 14.8 & $\ldots$ & 1.60 & 1.11 & $\ldots$ \\
\hline -.. & -... & --- & -- & $\cdots$ & $\cdots$ & $\ldots$ & .000 & $\ldots$ & 11.2 & $\cdots$ & 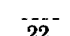 & 1.25 & $\cdots$ \\
\hline .6 & $\cdots$ & $\cdots$ & $\cdots$ & 1,200 & $\cdots$ & $\cdots$ & $\cdots$ & .04 & 4.7 & $\cdots$ & 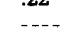 & $\cdots$ & $\cdots$ \\
\hline$\cdots$ & $\cdots$ & $\cdots$ & $\cdots$ & $\cdots$ & $-\cdots$ & $\cdots$ & .00 & -.- & 10.0 & $\ldots$ & 037 & .00 & $\cdots$ \\
\hline$\cdots$ & 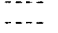 & $\cdots$ & .... & $-\cdots$ & --.- & 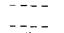 & .008 & 8 & 6.8 & $\cdots$ & .031 & .000 & $\cdots$ \\
\hline$\ldots$ & $\cdots$ & .... & $\cdots$ & $\ldots-$ & 2,000 & 7.2 & $\ldots$ & & & $-\cdots$ & 07 & 00 & - \\
\hline$\ldots$ & $\ldots$ & - & 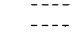 & 1,400 & 2,200 & 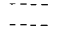 & .024 & 7.9 & $\begin{array}{l}18.0 \\
18.0\end{array}$ & $\cdots$ & .01 & .00 & $\cdots$ \\
\hline --. & $\cdots$ & $\cdots$ & $\cdots$ & 1,600 & & 6.6 & & .08 & 19.3 & $\ldots$ & $\ldots$ & .9 & 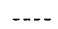 \\
\hline$\cdots$ & --- & --- & -..- & 150 & 2,200 & 7.9 & .00 & $\cdots$ & 8.8 & $\cdots$ & ... & .00 & $\cdots$ \\
\hline$\cdots$ & , & $\ldots$ & $\cdots$ & $\begin{array}{l}1,000 \\
1,600\end{array}$ & 2300 & 7.5 & 015 & 1.08 & 3.1 & $\cdots$ & 010 & .0 & \\
\hline$\ldots$ & -.-- & -- & 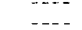 & 1,400 & 2,000 & $7 . \overline{9}$ & (1) & $\begin{array}{l}10.0 \\
10.4\end{array}$ & 7.9 & $\ldots$ & .010 & .0 & $\cdots$ \\
\hline$\cdots$ & -..- & $\cdots$ & $\cdots$ & 1,400 & 2,000 & $\cdots$ & .014 & 1.6 & 2.8 & $\cdots$ & .12 & .07 & .... \\
\hline .9 & $\cdots$ & - & --o- & 1,400 & 2,000 & 7.7 & .006 & $\begin{array}{l}0.0 \\
4.9\end{array}$ & $\begin{array}{l}.2 .2 \\
4.8\end{array}$ & $\cdots$ & .24 & .04 & -... \\
\hline - & 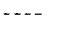 & & -..- & 1,600 & 2,300 & ---- & .008 & .4 & 1.0 & -... & .16 & .00 & $\ldots$ \\
\hline$\cdots$ & -- & 1.3 & --- & 1,600 & 2,400 & $\cdots$ & .038 & 2.0 & .35 & $\cdots$ & 1.04 & .00 & $\cdots$ \\
\hline$\cdots$ & $\cdots$ & .28 & $\cdots$ & $\begin{array}{l}1,900 \\
1,500\end{array}$ & $\begin{array}{l}2,700 \\
2,300\end{array}$ & $\cdots$ & .046 & $\begin{array}{l}1.4 \\
2.1\end{array}$ & $\begin{array}{l}1.7 \\
1.6\end{array}$ & - & $\cdots$ & ${ }_{11}{ }^{.00}$ & $\ldots$ \\
\hline 4 & -...- & -..- & 46,000 & 1,800 & 2,400 & 9.9 & $\ldots$ & $\ldots$ & $\ldots$ & 24 & 0 & $\ldots$ & .11 \\
\hline 3 & $\cdots$ & $\cdots$ & 12,000 & 1,200 & 1,800 & 10.9 & - & $\ldots$ & $\cdots$ & 16 & 0 & $\ldots$ & 0 \\
\hline$\cdots$ & 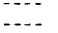 & . & 1,580 & $\cdots$ & $\cdots$ & 10.7 & .04 & $\ldots$ & $\cdots$ & $\cdots$ & $\cdots$ & $-\cdots$ & $\ldots$ \\
\hline 1 & - & $-\cdots$ & 1,450 & 1100 & $-\cdots$ & 10.6 & $-\cdots$ & $330^{-\cdots}$ & $\cdots$ & $\cdots$ & $\cdots$ & 1 & $\cdots$ \\
\hline 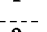 & $\cdots$ & -..- & 2,100 & , & & & .13 & 880 & $\cdots$ & 0 & $1.0^{--}$ & 1.4 & 4 \\
\hline $\begin{array}{l}3 \\
1\end{array}$ & $\cdots$ & 4.8 & $\begin{array}{l}500 \\
640\end{array}$ & $\begin{array}{r}1,200 \\
890\end{array}$ & $\begin{array}{l}1,600 \\
1,200\end{array}$ & $\begin{array}{l}8.2 \\
9.4\end{array}$ & .20 & $\begin{array}{r}919 \\
2500\end{array}$ & $\cdots$ & $\cdots$ & $\ldots$ & $-\cdots$ & $\cdots$ \\
\hline & --.- & . & -... & 1,200 & - & 9.3 & $\cdots$ & 152 & $\cdots$ & $\cdots$ & $\cdots$ & .05 & $\cdots$ \\
\hline$\cdots$ & 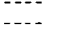 & - & $\cdots$ & $\begin{array}{r}768 \\
1,900\end{array}$ & $\ldots$ & $\begin{array}{r}9.3 \\
10.1\end{array}$ & $\cdots$ & $\begin{array}{l}220 \\
220\end{array}$ & 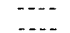 & $\cdots$ & $\cdots$ & $\begin{array}{l}.06 \\
.37\end{array}$ & 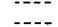 \\
\hline
\end{tabular}


TABLE 4.-Chemical analyses of the industrial wastes of

\begin{tabular}{|c|c|c|c|c|c|c|c|c|c|c|c|c|c|}
\hline 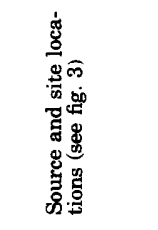 & 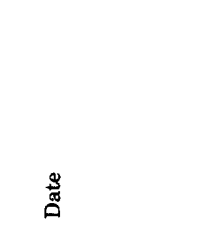 & 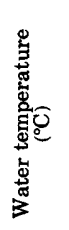 & 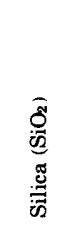 & 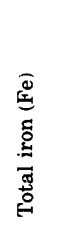 & 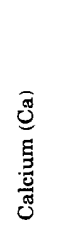 & 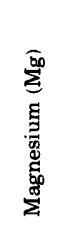 & 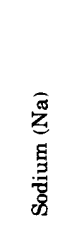 & 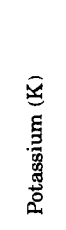 & 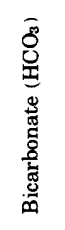 & 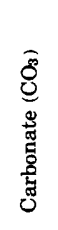 & 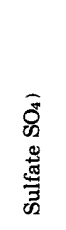 & 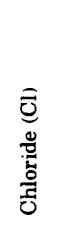 & 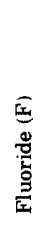 \\
\hline $\begin{array}{l}\text { Ditch. Water } \\
\text { softener and } \\
\text { laundry } \\
\text { (site A). }\end{array}$ & $\begin{array}{r}10-19-48- \\
5-22-51 \\
71-27-51 \\
11-30-51 \\
5-13-52 \\
5-25\end{array}$ & $\begin{array}{c}\cdots \\
\cdots \\
\cdots \\
\cdots-38 \\
\cdots\end{array}$ & $\begin{array}{r}118 \\
8 \\
31 \\
36\end{array}$ & $\begin{array}{r}50 \\
0 \\
400 \\
0 \\
0-\end{array}$ & $\begin{array}{r}15 \\
15 \\
40 \\
15 \\
-15\end{array}$ & $\begin{array}{r}23 \\
0 \\
1 \\
1 \\
-1\end{array}$ & $\begin{array}{r}723 \\
106 \\
1,200 \\
215 \\
-150\end{array}$ & $\begin{array}{c}\cdots \\
-9 \\
61 \\
-9\end{array}$ & \begin{tabular}{r}
0 \\
0 \\
$-\ldots$ \\
\hdashline-0 \\
$\cdots$
\end{tabular} & $\begin{array}{r}91 \\
70 \\
157 \\
222 \\
-19-0\end{array}$ & $\begin{array}{r}64 \\
52 \\
63 \\
54 \\
\end{array}$ & $\begin{array}{l}57 \\
32 \\
68 \\
70\end{array}$ & $\begin{array}{r}.5 \\
.0 \\
.2 \\
.6 \\
-.-\end{array}$ \\
\hline $\begin{array}{l}\text { Discharge to } \\
\text { city sewwer } \\
\text { (site C). }\end{array}$ & $\begin{array}{l}6-2-70 \\
6-30 \\
6-7-71 \\
1-7 \ldots\end{array}$ & $\ldots$ & $\cdots$ & - & $\ldots$ & $\ldots$ & 470 & $\ldots$ & $\overline{2} 7 \overline{2}$ & $\cdots$ & $\cdots$ & 234 & .41 \\
\hline
\end{tabular}

${ }^{1}$ At entrance to drain (ditch).

TABLE 5.-Chemical analyses of the domestic and industrial [Constituents in milligrams per litre, except total iron, boron, and arsenic in micrograms per litre;

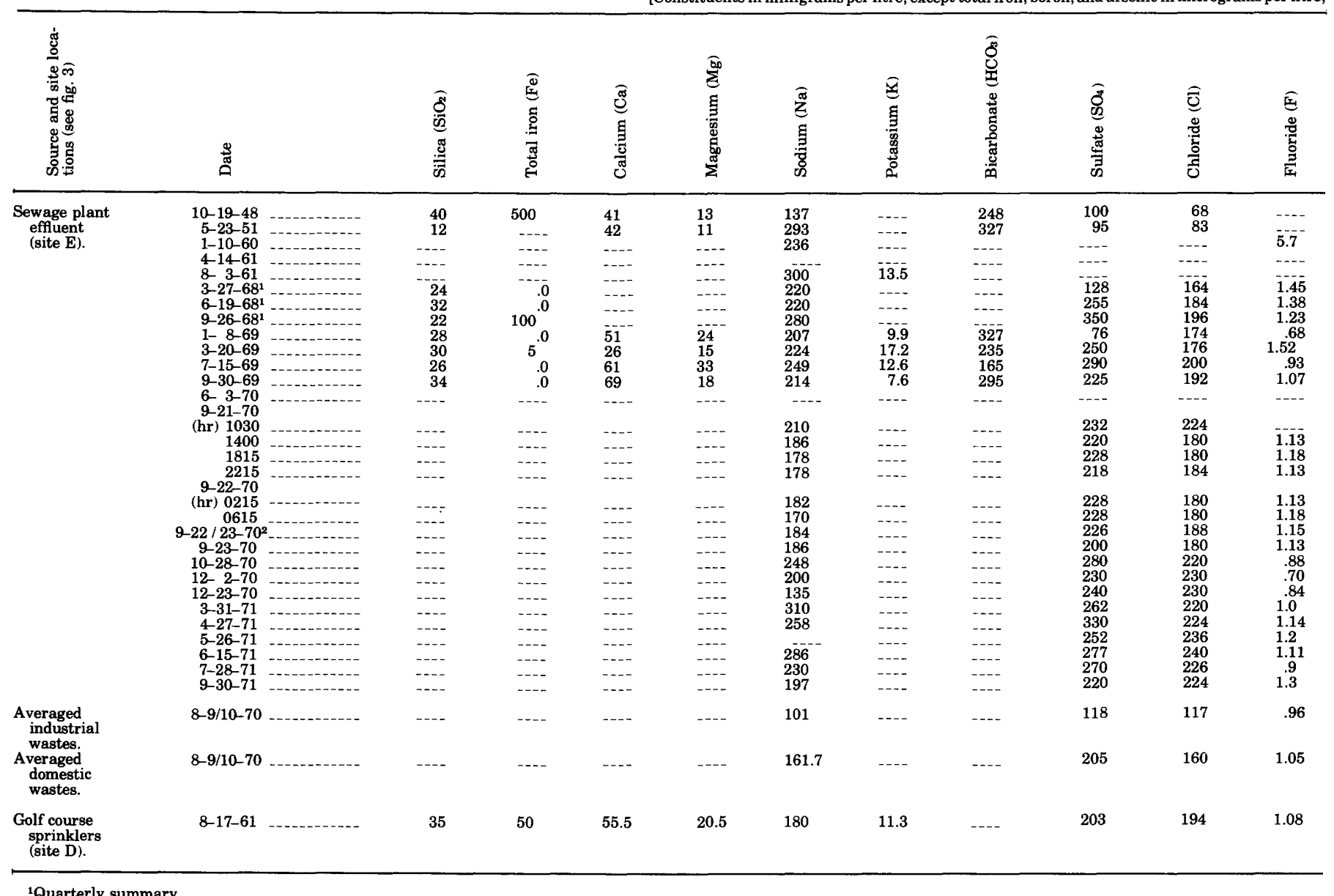

the river-channel deposits from abandoned upstream waste-discharge sites A and B (fig. 3).

Distribution of chemical substances in ground water beneath the present city of Barstow treatment facility (site C, fig. 3) reflects the quality, quantity, and timing of sewage percolation. Estimates by the California Department of Public Health (1970, p. 7) of the rate of waste percolation from the city oxidation ponds indicate that percolation from pond 2 is approximately 10 times that of the other ponds. Pond 2 has a greater percolation rate than the other ponds because when the other ponds are either full, drying, or under repair, six lagoons adjacent to pond 2 are used for percolation of the wastes. These lagoons, located between the ponds and the center of the river (fig. 3), are constructed of river sand and are capable of percolating large volumes of waste effluent. The two irregularities in the shallow plume of degraded water that are shown in figures $6,8-11$ reflect and are 


\begin{tabular}{|c|c|c|c|c|c|c|c|c|c|c|c|c|c|}
\hline 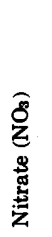 & 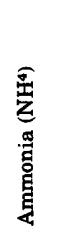 & 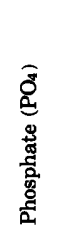 & 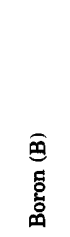 & 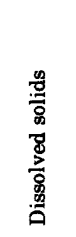 & 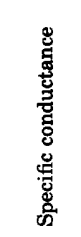 & 窝 & $\begin{array}{c}\overrightarrow{\mathrm{g}} \\
\stackrel{\mathbb{g}}{\mathbb{E}} \\
\end{array}$ & 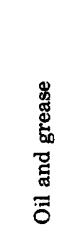 & 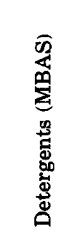 & 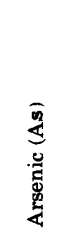 & 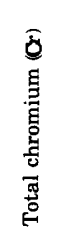 & 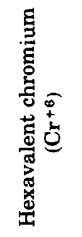 & 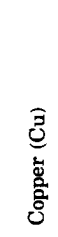 \\
\hline $\begin{array}{c}8 \\
2 \\
1 \\
0 \\
-\end{array}$ & $\begin{array}{c}-\cdots \\
-\cdots \\
-\cdots- \\
-\cdots \\
-\cdots-\end{array}$ & $\begin{array}{c} \\
-.- \\
--. \\
-\cdots \\
-\cdots\end{array}$ & $\begin{array}{r}1,250 \\
60 \\
1,000 \\
2,400 \\
-\end{array}$ & $\begin{array}{r}2,400 \\
311 \\
2,700 \\
696\end{array}$ & $\begin{array}{r}7,000 \\
631 \\
13,000 \\
1,400 \\
-\ldots . .\end{array}$ & $\begin{array}{l}11.6 \\
10.8 \\
12.4 \\
11.1 \\
-\ldots .\end{array}$ & $\begin{array}{l} \\
\cdots \\
\cdots \\
\cdots . . \\
.02\end{array}$ & $\begin{array}{c} \\
--.- \\
\cdots \\
\cdots \cdots \\
-\cdots- \\
-\cdots\end{array}$ & 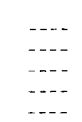 & $\begin{array}{r}- \\
37 \\
-\cdots\end{array}$ & $\begin{array}{l}\cdots \\
0^{-\cdots} \\
0\end{array}$ & $\begin{array}{l}-. . \\
\cdots-. \\
\cdots \cdots \\
\cdots--\end{array}$ & $\begin{array}{l}\cdots \\
0 \\
0 \\
-\cdots\end{array}$ \\
\hline 4 & 3 & $\cdots$ & 800 & 580 & 983 & $10 . \overline{6}$ & .10 & 67 & $\cdots$ & $\cdots$ & $-\cdots$ & $0^{-}$ & --- \\
\hline $\begin{array}{l}-. . \\
-.05\end{array}$ & $\begin{array}{l}-\cdots \\
\cdots \\
\cdots\end{array}$ & $\begin{array}{l}9.7 \\
3.4 \\
-\end{array}$ & $\begin{array}{l}--- \\
-200\end{array}$ & $1, \overline{590}$ & $\begin{array}{l}2,300 \\
2,400 \\
2,300\end{array}$ & $\begin{array}{r}3.9 \\
4.3 \\
-\end{array}$ & $\begin{array}{l}.100 \\
.061 \\
.28\end{array}$ & $\begin{array}{r}42.7 \\
\cdots \\
\hdashline-\end{array}$ & $\begin{array}{l}32 \\
64 \\
1.8\end{array}$ & $\begin{array}{c}-\cdots \\
\cdots- \\
\cdots-\end{array}$ & $\begin{array}{l}.30 \\
.24 \\
.--\end{array}$ & $\begin{array}{l}.000 \\
.000 \\
.050\end{array}$ & $\begin{array}{l}\cdots \\
-\cdots \\
--\cdot\end{array}$ \\
\hline
\end{tabular}

${ }^{2}$ At end of drain (ditch).

wastes of the U.S. Marine Corps Supply Center (Nebo)

water temperature in degrees Celsius; specific conductance in micromhos at $25^{\circ} \mathrm{C}$; and $\left.\mathrm{pH}\right]$

\begin{tabular}{|c|c|c|c|c|c|c|c|c|c|c|c|}
\hline 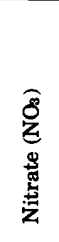 & 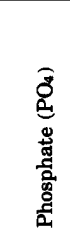 & 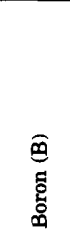 & 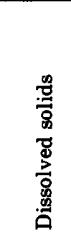 & 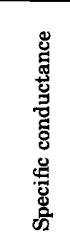 & 窝 & 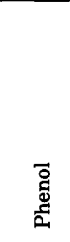 & 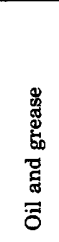 & 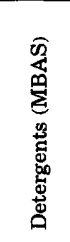 & 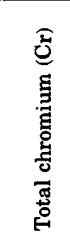 & 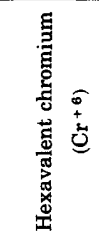 & 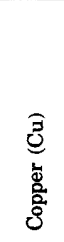 \\
\hline$-\cdots$ & $\cdots$ & $\begin{array}{r}1,400 \\
710\end{array}$ & $\begin{array}{l}506 \\
569\end{array}$ & $\begin{array}{r}820 \\
1000\end{array}$ & $\begin{array}{l}7.2 \\
7.5\end{array}$ & 004 & 79 & $\cdots$ & 002 & --- & $\cdots$ \\
\hline --.- & ---- & $\begin{array}{r}710 \\
1,600\end{array}$ & $\begin{array}{r}569 \\
-\end{array}$ & $\begin{array}{l}1,000 \\
1,400\end{array}$ & $\begin{array}{r}7.5 \\
-\end{array}$ & 0.04 & 79 & $\cdots$ & $\begin{array}{c}0.02 \\
\ldots\end{array}$ & --- & -- \\
\hline 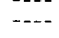 & 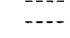 & - & 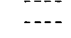 & - & $\cdots$ & $\cdots$ & $-\cdots$ & 2.5 & $\cdots$ & $\cdots$ & $\cdots$ \\
\hline 1.8 & 3.0 & $\begin{array}{r}1,400 \\
900\end{array}$ & 780 & $\cdots$ & 7.5 & .018 & $\cdots$ & $\begin{array}{l}5.0 \\
.18\end{array}$ & --.- & -..- & - \\
\hline .0 & 2.6 & $\begin{array}{r}30 \\
\end{array}$ & 840 & $\cdots$ & 9.2 & .00 & - & .06 & $\cdots$ & $\cdots$ & $\ldots$ \\
\hline $\begin{array}{r}2.7 \\
23.9\end{array}$ & $\begin{array}{r}2.8 \\
12.8\end{array}$ & $\begin{array}{r}850 \\
2500\end{array}$ & $\begin{array}{l}830 \\
940\end{array}$ & $\cdots$ & $\begin{array}{l}9.4 \\
81\end{array}$ & $<.06$ & $\cdots$ & .13 & -..- & $\cdots$ & 0.1 \\
\hline $\begin{array}{r}20.5 \\
5.2\end{array}$ & 6.9 & $\begin{array}{l}2,000 \\
1,200\end{array}$ & $\begin{array}{l}940 \\
710\end{array}$ & -... & $\begin{array}{l}8.1 \\
9.4\end{array}$ & .018 & $\cdots$ & .06 & $\cdots$ & $\cdots$ & $\begin{array}{l}0.1 \\
.15\end{array}$ \\
\hline 4.0 & 1.4 & 1,730 & 790 & $\cdots$ & 9.0 & .00 & --.- & .03 & -- & - & .0 \\
\hline $\begin{array}{r}.0 \\
\hdashline-.\end{array}$ & $\begin{array}{l}5.8 \\
5.8\end{array}$ & $\begin{array}{r}820 \\
-\cdots\end{array}$ & $\begin{array}{r}780 \\
-\ldots .\end{array}$ & 1,700 & $\begin{array}{l}7.3 \\
7.6\end{array}$ & .003 & 41.3 & $\begin{array}{l}.0 \\
.80\end{array}$ & .012 & 0.000 & .0 \\
\hline .... & 6 & 1,280 & 990 & 1,500 & 9.6 & .016 & $\ldots$ & .68 & .01 & .00 & $\ldots$ \\
\hline- & 17 & $\begin{array}{l}1,120 \\
1,120\end{array}$ & 960 & 1,500 & 9.3 & .032 & 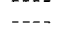 & .48 & .01 & .00 & $\cdots$ \\
\hline$-\cdots$ & $\begin{array}{l}12 \\
12\end{array}$ & $\begin{array}{l}1,420 \\
1,180\end{array}$ & $\begin{array}{l}900 \\
860\end{array}$ & $\begin{array}{l}1,400 \\
1,300\end{array}$ & $\begin{array}{l}9.0 \\
8.8\end{array}$ & $\begin{array}{l}.028 \\
.048\end{array}$ & - & .52 & $\begin{array}{l}.00 \\
.01\end{array}$ & $\begin{array}{l}.00 \\
.00\end{array}$ & $\cdots$ \\
\hline -..- & 12 & 1,320 & 860 & 1,300 & 8.6 & .028 & $\ldots$ & 22 & .01 & 00 & -..- \\
\hline -..- & 12 & 1,460 & 830 & 1,300 & 8.7 & .013 & $\cdots$ & .42 & .00 & .00 & --.- \\
\hline-- & 12 & 1,300 & 900 & 1,400 & 9.0 & .032 & 11.5 & .45 & .01 & .00 & -..- \\
\hline --- & .... & 1,120 & 960 & -- & 8.6 & .032 & 11.5 & .44 & --.- & .00 & ---- \\
\hline$-\cdots$ & --- & 830 & 1,200 & $\cdots$ & 9.3 & .003 & 3 & .26 & --- & .01 & --- \\
\hline$-\cdots$ & --. & $\begin{array}{l}1,600 \\
1,000\end{array}$ & 990 & --.- & 8.5 & .001 & 6.3 & $\begin{array}{l}.56 \\
18\end{array}$ & -..- & .00 & --- \\
\hline$\cdots$ & -.. & $\begin{array}{l}1,000 \\
700\end{array}$ & $\begin{array}{r}1,100 \\
990\end{array}$ & $\cdots$ & $\begin{array}{r}70.4 \\
10.0\end{array}$ & $\begin{array}{l}.003 \\
.002\end{array}$ & $\begin{array}{r}6.4 \\
14.5\end{array}$ & $\begin{array}{l}.48 \\
.32\end{array}$ & $\cdots$ & .00 & $\cdots$ \\
\hline --.- & $\ldots$ & & 1,140 & - & 9.2 & .009 & 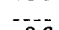 & .76 & $\ldots$ & .02 & -... \\
\hline --- & $\cdots$ & 2,300 & 1,160 & ---- & 9.8 & .006 & 3.6 & .62 & --- & .00 & -..- \\
\hline$\cdots$ & $\ldots$ & $\begin{array}{l}1,800 \\
1550\end{array}$ & 1,230 & --- & $\begin{array}{l}8.8 \\
86\end{array}$ & .001 & 8.2 & .44 & --- & .01 & ---- \\
\hline$\cdots$ & 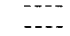 & $\begin{array}{r}1,050 \\
900\end{array}$ & $\begin{array}{l}1,100 \\
1,040\end{array}$ & 1,500 & $\begin{array}{r}8.60 \\
.9 .0\end{array}$ & .036 & 4.2 & .027 & $\cdots$ & .00 & $\cdots$ \\
\hline -..- & 11.3 & 40 & .... & -.-- & 8.5 & -... & -.-- & 1.33 & --.- & $\ldots$ & -..- \\
\hline$\ldots$ & 13.07 & 1,190 & --.-. & .... & ...- & -..- & -... & .36 & .... & -... & $\ldots$ \\
\hline--- & 11.0 & 2,000 & 1,000 & 1,500 & ...- & .... & $\ldots$ & .3 & -... & .... & -- \\
\hline
\end{tabular}

${ }^{2}$ Numerical average.

attributed to this irregular distribution of recharge. The first irregularity is located beneath pond 2 and results from waste percolation from the lagoons; the other is near ponds 6 and 7. Both irregularities are elongated downstream (section $A-A^{\prime}$ ) and toward the center of the river (figs. $6,8,9$, sections $B-B^{\prime}$ and $C-C^{\prime}$ ) in response to the local system of ground-water flow.

The hydrologic effects on the aquifer system caused by the city's waste discharge are somewhat similar to the effects caused by flood recharge. The discharge and concomitant recharge to the aquifer have depressed or displaced underlying ground water of different quality. Section $A-A^{\prime}$ (figs. 6, 8-11) suggests that a body of better quality ground water has been isolated between the deeper, older degraded ground water and the younger plume produced by present waste percolation. The quality of ground water in the shallow plume becomes better with depth. Chemical analyses of ground-water 


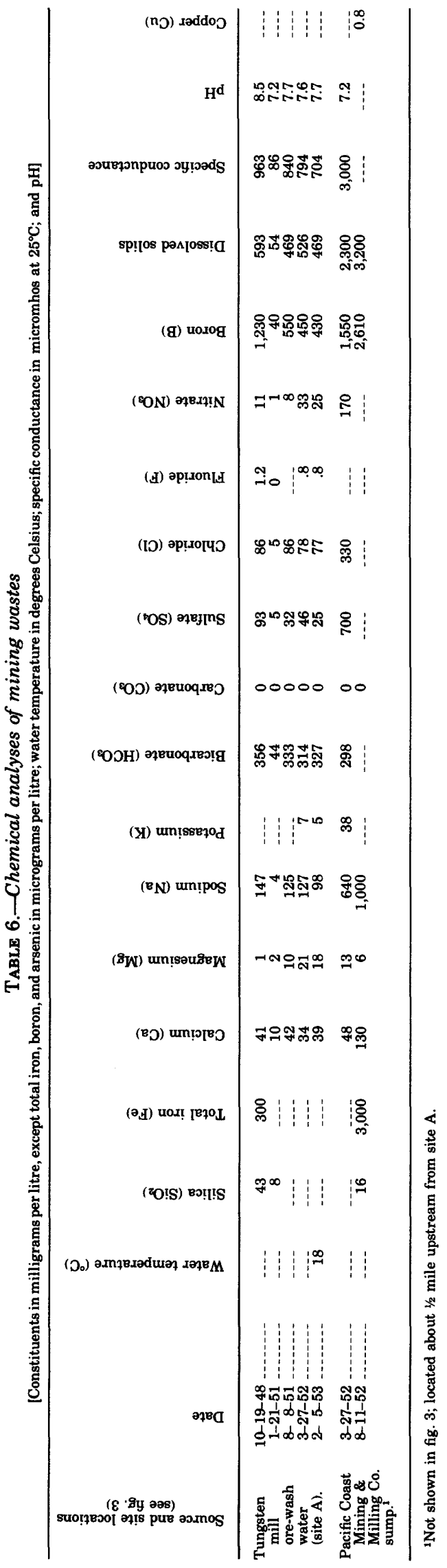

samples from shallow wells adjacent to the present oxidation ponds are very similar to the analyses of waste effluent in each of the ponds.

Recharge to ground water from irrigation of the USMC golf course with treated effluent has produced an underlying body of degraded ground water that reflects both the quality and quantity of the effluent used. The vertical distribution of water quality beneath the golf course is similar to that described beneath the city's treatment facility (figs. 6, 8-11), except for the absence of the deeper, older plume of poorer quality water. The quality of ground water beneath the golf course is much poorer at a depth of $50 \mathrm{ft}(15 \mathrm{~m})$ than at a depth of $100 \mathrm{ft}$ $(31 \mathrm{~m})$ below land surface. The only apparent source for this poor-quality ground water is the irrigation-return water that had been concentrated by domestic and industrial use, by evapotranspiration, and by solution of fertilizers prior to and during infiltration.

Chemical and hydrologic data indicate that the distribution of water quality in the vicinity of the golf course is influenced by the Waterman fault and by extensive pumping at the USMC Supply Center. Because the Waterman fault tends to retard groundwater flow, drawdown of the water table caused by pumping at the USMC Supply Center is exaggerated and tends to reverse the natural ground-water gradient. This reversal in gradient has resulted in ground-water flow from areas of poor-quality water near the golf course and the river-channel deposits toward the USMC Supply Center wells (figs. 10 and 11 , section $D-D^{\prime}$ ).

\section{DISSOLVED SOLIDS}

Dissolved solids are a measure of the amount of dissolved mineral matter in water and may be (1) determined by totaling all anions and cations analyzed, (2) determined by weighing the dry residue after evaporation, or (3) approximated from specific conductance.

In the Barstow area the concentration of dissolved solids in ground water ranges from less than 500 to more than $2,000 \mathrm{mg} / \mathrm{l}$ (Hughes and Patridge, 1973). Available data suggest that the concentrations of dissolved solids in floodflows that recharge the aquifer are about 150 $\mathrm{mg} / \mathrm{l}$ (Miller, 1969, p. 19). Very few wells have been drilled south of the river in the older, more consolidated deposits; therefore, chemical data are sparse on ground-water inflow from these areas. Analyses of ground-water samples from wells $9 \mathrm{~N} / 1 \mathrm{~W}-15 \mathrm{Q} 1$ and $-15 \mathrm{Q} 2$ (fig. 3) and wells $9 \mathrm{~N} / 1 \mathrm{~W}-27 \mathrm{D} 1$ and $9 \mathrm{~N} / 1 \mathrm{E}$ -19J1-5 (not shown in fig. 3) indicate that dissolved solids in ground water south of the river are generally high and vary directly with well depth. The concentrations of dissolved solids in water from wells $9 \mathrm{~N} / 1 \mathrm{E}-19 \mathrm{~J} 1$ 

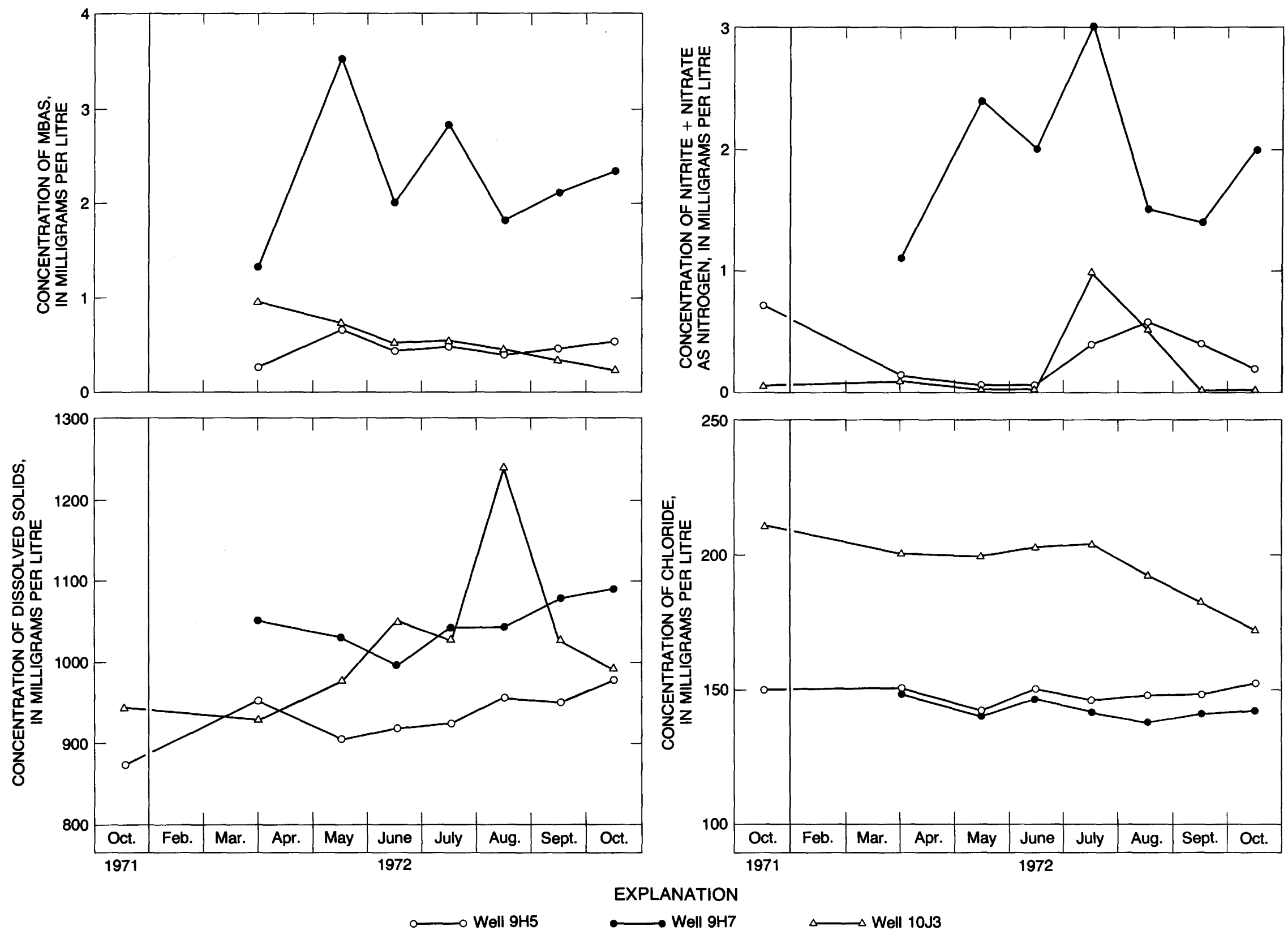

FIGURE 5.-Change in concentration of selected chemical constituents in wells $9 \mathrm{~N} / 1 \mathrm{~W}-9 \mathrm{H} 5,-9 \mathrm{H} 7$, and $-10 \mathrm{~J} 3$. 
and $-19 \mathrm{~J} 5$, which are 250 and $660 \mathrm{ft}$ ( 76 and $201 \mathrm{~m}$ ) deep, range from $800 \mathrm{mg} / \mathrm{l}$ in the shallow well to $2,300 \mathrm{mg} / \mathrm{l}$ in the deep well. Water from other wells south of the river (9N/1W-15Q1, -15Q2, and -27D1) contains less than $800 \mathrm{mg} / \mathrm{l}$ of dissolved solids. Robson (1974; Hughes and Robson, 1973) estimated that ground water entering the area from the south contained an average of $1,000 \mathrm{mg} / \mathrm{l}$ of dissolved solids. The effect of this inflow on the quality of water in the river-channel deposits is probably minor compared with the quantity and quality of municipal- and industrial-waste disposal to ground water. Volume of inflow from the south has been estimated to be 120 acre-ft $\left(0.15 \mathrm{hm}^{3}\right)$ per year (table 2$)$. Inflow from the consolidated rocks to the north is probably negligible.

Available data suggest that the greatest impact on quality of ground water in the project area has resulted from the large volumes of ground water used for domestic, industrial, and agricultural purposes. Water used for these purposes and returned to ground water has increased in dissolved solids by (1) addition of solid or liquid concentrates, such as detergents, fertilizers, rust inhibitors, oil and grease, and a variety of organic matter; and (2) evapotranspiration associated with agriculture and with exposure in waste-treatment facilities. The concentrations of dissolved solids in industrial and municipal wastes have averaged more than $1,000 \mathrm{mg} / \mathrm{l}$, and some effluent from the railroad facilities has exceeded $2,500 \mathrm{mg} / \mathrm{l}$ of dissolved solids (tables $3,4,5$, and 6).

The distribution of dissolved solids in ground water in the Barstow area is illustrated in sections $A-A^{\prime}$ and $B-B^{\prime}$ (fig. 6). The concentration of dissolved solids in water from well $9 \mathrm{~N} / 1 \mathrm{~W}-10 \mathrm{~J} 4$ is very similar to waste water in the city's oxidation ponds. During 1970, dissolved solids in these ponds averaged more than 950 $\mathrm{mg} / \mathrm{l}$ (table 3). In 1972 dissolved solids in ground water from well $9 \mathrm{~N} / 1 \mathrm{~W}-10 \mathrm{~J} 4$ were approximately $1,000 \mathrm{mg} / \mathrm{l}$ (Hughes and Patridge, 1973). This well is about $300 \mathrm{ft}$ $(91 \mathrm{~m})$ downstream from the ponds.

The adverse effects on ground water caused by using treated and reclaimed sewage on the golf course are indicated by water-quality data from wells $9 \mathrm{~N} / 1 \mathrm{~W}-$ $11 \mathrm{P} 1,-11 \mathrm{Q} 1$, and $-11 \mathrm{R} 1$ (table 7) and the distribution of nitrogen and chloride in section $D-D^{\prime}$ (figs. 10 and 11). Wells $9 \mathrm{~N} / 1 \mathrm{~W}-11 \mathrm{P} 1,-11 \mathrm{Q} 1$, and $-11 \mathrm{R} 1$ are approximately $50 \mathrm{ft}(15.2 \mathrm{~m})$ deep, and their ground water contains a very high concentration of chloride, sulfate, and dissolved solids compared with adjacent deeper wells $9 \mathrm{~N} / 1 \mathrm{~W}-11 \mathrm{P} 2,-11 \mathrm{Q} 2$, and $-11 \mathrm{R} 2$, which are about $100 \mathrm{ft}(30.5 \mathrm{~m})$ in depth. The distribution of chloride and nitrogen in section $D-D^{\prime}$ appears to be influenced by pumping at the USMC Supply Center and by the barrier effects of the Waterman fault.

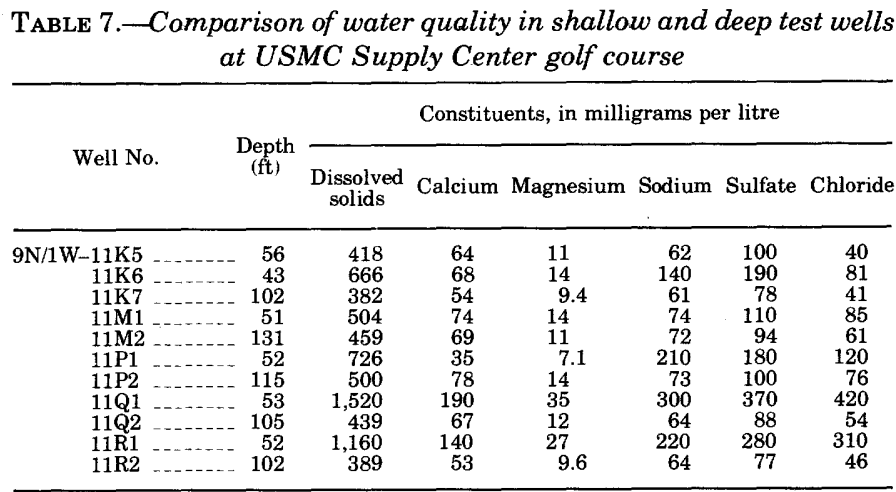

\section{DETERGENTS (AS MBAS)}

Methyl blue active substances (MBAS) refers to a colormetric test used to measure the apparent concentration of synthetic detergents in water. This test does not distinguish between the nonbiodegradable ABS (alkyl benzene sulfonate) and the biodegradable LAS forms. Synthetic detergents were first used in the United States about 1946, and now they constitute the principal washing compounds for industrial and domestic purposes. These compounds contribute to waterquality problems when they percolate to ground water, usually as part of the effluent from industrial and domestic waste sources. Problems associated with treatment and disposal of water that contains detergents were partly solved in 1964 with the development of the biodegradable LAS and with restrictions placed on the use of the nonbiodegradable ABS.

Experiments conducted on the biodegradation potential of LAS and ABS (Halvorson and Ishaque, 1969, p. 571-576) indicated that under proper aerobic conditions, LAS would biodegrade by 97.5 percent in 120 hours at $25^{\circ} \mathrm{C}$ while $\mathrm{ABS}$ remained unaffected. Under similar aerobic conditions, the rate of biodegradation of LAS at a temperature of $10^{\circ} \mathrm{C}$ decreased by a factor of 2.5 , and at $2+0.1^{\circ} \mathrm{C}$ no biodegradation of LAS was observed over a period of 12 days. Similar experiments for anaerobic conditions showed that neither LAS nor ABS was appreciably biodegraded at $25^{\circ} \mathrm{C}$. The results of these experiments strongly suggest that the concentration of ABS detergents in domestic and industrial wastes in the project area during 1946-65 biodegraded very little prior to percolation into the river-channel deposits. Since 1965, the amount of biodegradation of detergents was probably largely dependent on water temperature in the treatment plant. Winter temperature in Barstow averages $10^{\circ} \mathrm{C} \pm$ with nighttime temperature falling below $2^{\circ} \mathrm{C}$ (data from National Weather Service, 1972). During summer months, temperatures probably are sufficiently high to permit maximum biodegradation.

Synthetic detergents are not indigenous to ground 

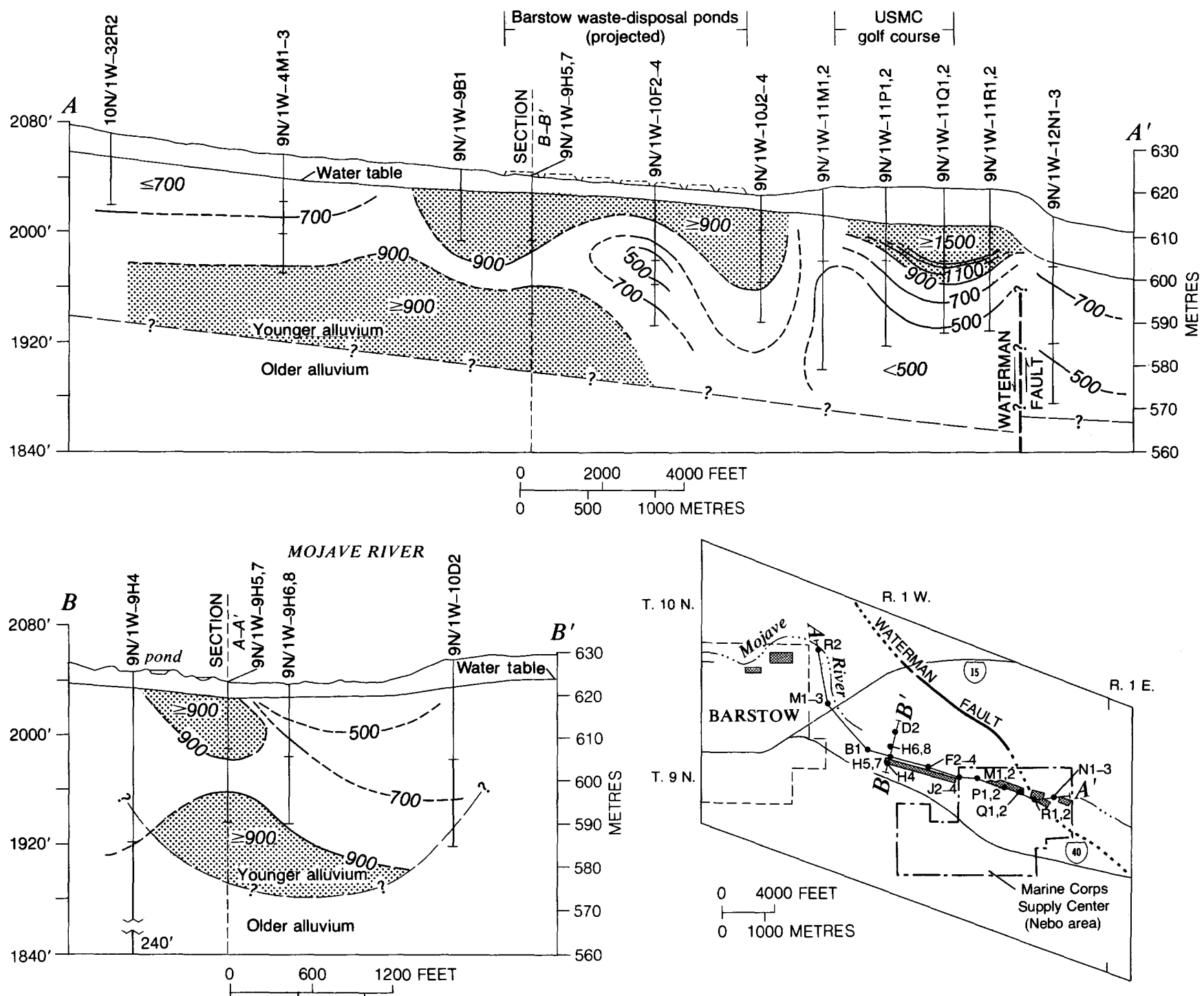

Diagrammatic map showing location of sections

\section{EXPLANATION}

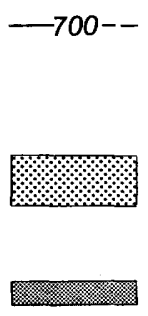

Line of equal dissolved-solids concentration, March 1972 - Dashed where approximate; intervals in milligrams per litre, variable as shown

Areas of high dissolved-solids concentration - Dissolved solids $\geq 900 \mathrm{mg} / \mathrm{l}$

Waste-disposal sites - See figure 3

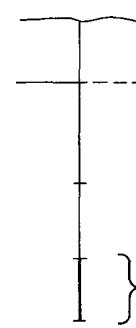

Land surface

Water table - Dashed where approximately located

Point sampled - Generally a test well, 2-ft $(0.6-m)$ perforated interval

Perforated interval sampled - Domestic, irrigation, or supply well

DATUM IS MEAN SEA LEVEL

VERTICAL SCALES EXAGGERATED

FIGURE 6.-Vertical distribution of dissolved solids.

water; therefore they can be used to detect degraded and | the 1953-68 city of Barstow's waste-disposal facility to polluted ground water. The area of ground water the vicinity of pond 7 at the present treatment facility generally affected by detergent concentrations of 0.2 (fig. 7). Sections $A-A^{\prime}$ and $C-C^{\prime}$ (fig. 8) illustrate the $\mathrm{mg} / \mathrm{l}$ or more extends from the approximate location of vertical distribution of detergents (as MBAS) in ground 


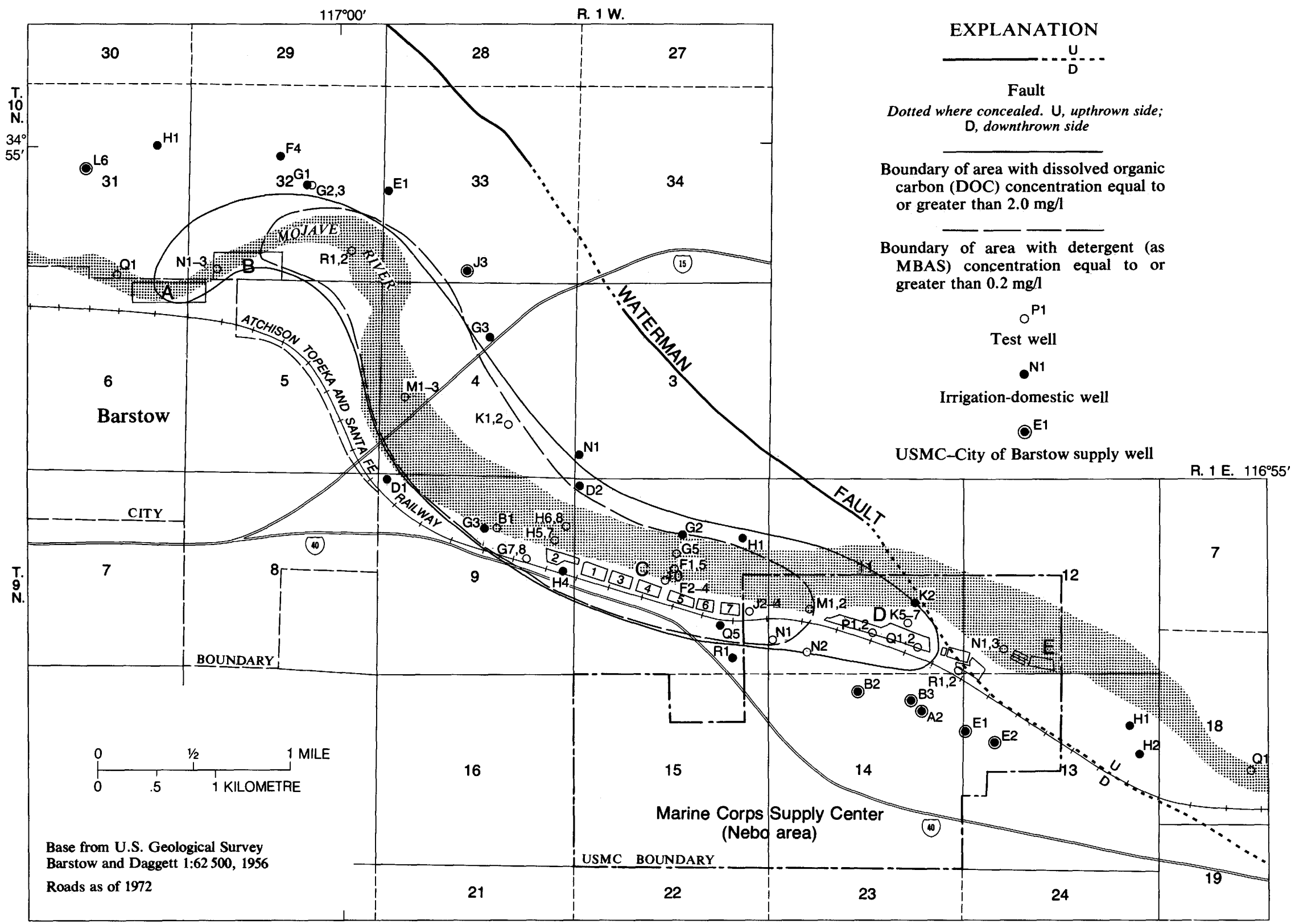



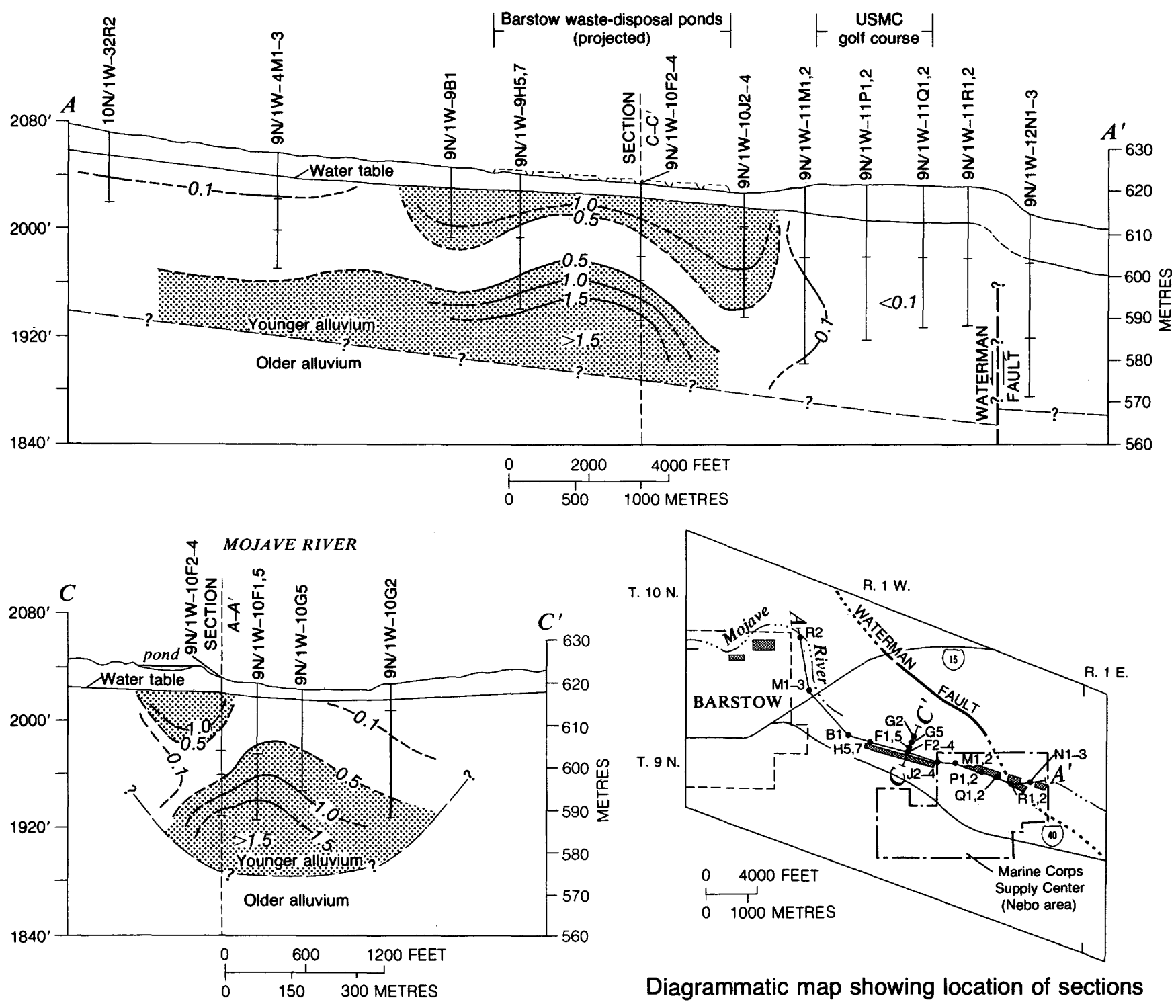

Diagrammatic map showing location of sections

EXPLANATION

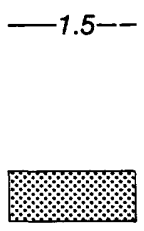

Line of equal detergent (as MBAS) concentration, March 1972 - Dashed where approximate; intervals in milligrams per litre, variable as shown

Areas of high detergent (as MBAS) concentration - Detergents $\geq 0.5 \mathrm{mg} / \mathrm{l}$

Waste disposal sites - See figure 3

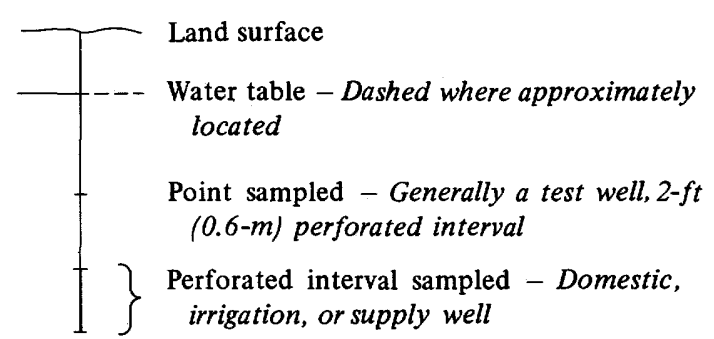

DATUM IS MEAN SEA LEVEL VERTICAL SCALES EXAGGERATED

FIGURE 8.-Vertical distribution of detergents (as MBAS). 
water. The higher concentrations of detergents (as MBAS) occur at depths greater than about $60-100 \mathrm{ft}$ $(18-31 \mathrm{~m})$ below land surface. Ground-water samples that were analyzed from this deep zone during 1972 fluctuated in concentration from 1.3-3.6 mg/l (well $9 \mathrm{~N} / 1 \mathrm{~W}-9 \mathrm{H} 7$, fig. 5) and probably reflect pre-1964 waste effluent that was high in ABS-type detergents. The lower concentration of detergents (as MBAS) in ground-water samples from shallow wells $9 \mathrm{~N} / 1 \mathrm{~W}-9 \mathrm{H} 5$ and -10J3 (fig. 5) are interpreted to be a result of more complete biodegradation associated with the current use of LAS-type detergents. Locally, concentrations of detergents (as MBAS) in both the shallow and the deep ground-water zones are equal to or exceed the limits (ABS, $0.5 \mathrm{mg} / \mathrm{l}$, table 1) recommended by the U.S. Public Health Service (1962) for drinking water.

During this investigation only trace quantities of synthetic detergents (as MBAS) were found in water samples from the test wells augered adjacent to the USMC golf course and from the wells at the USMC Supply Center. The detergents in the effluent used to water the golf course (table 5) were probably consumed following initial biodegradation by adsorption or as a nutrient to the grass.

\section{DISSOLVED ORGANIC CARBON}

$\mathrm{DOC}$ is a quantitative parameter defined as that part of total organic carbon in water which passes through a 0.45-micrometre silver-membrane filter (Malcolm and Leenheer, 1972). Dissolved organic carbon reflects the presence of many individual organic chemical compounds soluble in water, such as synthetic detergents, phenolic compounds, oil and grease, herbicides, humic and fulvic acids, products of human-waste decomposition (indole and skatole), pesticides, and other watersoluble organic substances (L. A. Eccles, oral commun., 1972). As illustrated in figure 7 , analyses of ground water for DOC have outlined areas of and affected by municipal- and industrial-waste disposal and irrigation return.

A comparison of the areas degraded by detergents and by DOC (fig. 7) indicates a lack of detergents but the presence of appreciable quantities of DOC in ground water in vicinity of wells $10 \mathrm{~N} / 1 \mathrm{~W}-32 \mathrm{~N} 1-3$. The concentration of detergents in this half-mile reach may have been diminished by the large volume of flood recharge that occurred in 1969. More likely, the lack of detergents represents the downstream movement of the last waste discharged by the railroad in 1968. The distance (about $0.5 \mathrm{mi}$ or $0.8 \mathrm{~km}$ ) could be traveled within this 4-year time span at a flow rate of about 1.5 $\mathrm{ft} / \mathrm{d}$ (about $1 / 2 \mathrm{~m} / \mathrm{d}$ ). Those organic constituents that have a greater potential for being adsorbed onto the sediment may not have been appreciably affected by the flood recharge, and the organic compounds in the water samples may be the result of desorption. Thus, there seems to be a continuous source of DOC from material adsorbed onto the sediment. The concentrations of oil and grease, detergents (as MBAS), and COD (chemical oxygen demand) from ground water in wells $10 \mathrm{~N} / 1 \mathrm{~W}-$ $32 \mathrm{~N} 1,-\mathrm{N} 2$, and $-\mathrm{N} 3$ are low; thus they do not account for the organic compounds represented by the high DOC values of $4.6,5.1$, and $5.9 \mathrm{mg} / \mathrm{l}$.

Location of the downstream nose of the plume defined by DOC (fig. 7) suggests that degraded ground water has moved downstream sufficiently to be influenced by the barrier effects of the Waterman fault and by the pumping at the USMC Supply Center. Ground-water samples from wells $9 \mathrm{~N} / 1 \mathrm{~W}-11 \mathrm{M} 1,-11 \mathrm{M} 2,-11 \mathrm{P} 1$, $-11 \mathrm{P} 2,-12 \mathrm{~N} 1$, and $-12 \mathrm{~N} 3$ contained $1.3-2.4 \mathrm{mg} / \mathrm{l}$ of DOC. The highest concentrations of DOC in ground water in the project area were from wells near the city of Barstow's oxidation pond 7 (fig. 7), where water samples from wells $9 \mathrm{~N} / 1 \mathrm{~W}-10 \mathrm{~J} 4$ and $-10 \mathrm{Q} 5$ contained $6.3 \mathrm{mg} / \mathrm{l}$ of DOC. Both wells are shallow-25 and $58 \mathrm{ft}$ (7.6 and 18 $\mathrm{m}$ ) deep. Background levels of DOC for the nonaffected areas ranged from 0.0 to $1.0 \mathrm{mg} / \mathrm{l}$.

The vertical distribution of DOC in ground water in the project area is illustrated in sections $A-A^{\prime}$ and $C-C^{\prime}$ (fig. 9). A comparison of these DOC sections with similar sections for dissolved solids, detergents, and chloride indicates that flood recharge in the areas upstream from the present city oxidation ponds has had little effect on the concentrations of DOC. This uniformity of concentration of DOC with depth is not readily understood from available data, but it may be related to adsorption and desorption of organic compounds onto river-channel sediment.

\section{NITROGEN}

Nitrogen is abundant in nature. It constitutes about 80 percent of the atmosphere, is an essential constituent of protein in all living organisms, and is present in many mineral deposits. Briefly, nitrogen in organic matter undergoes bacterial decomposition from protein through amino acids to ammonia $\left(\mathrm{NH}_{3}, \mathrm{NH}_{4}\right),{ }^{1}$ nitrite $\left(\mathrm{NO}_{2}\right)^{2}$ and nitrate $\left(\mathrm{NO}_{3}\right){ }^{2}$ Photosynthesis is responsible for the reconstruction of the organic matter or a completion of the nitrogen cycle. In water, nitrogen generally takes the form of ammonia, organic nitrogen, ${ }^{1}$ nitrite, or nitrate (California Water Resources Control Board, 1963, p. 226). In the project area, the nitrogen in the forms of ammonia $\left(\mathrm{NH}_{3}\right)$, nitrite, and nitrate was used to identify quality distribution in ground water. The distribution of nitrogen shown in figure 10,

'Nitrogenous organic compounds are often determined by the Kjeldahl method which includes ammonia nitrogen (American Public Health Association, 1971, p. 469).

${ }^{2} \mathrm{Chemical}$ analyses for nitrite and nitrate are expressed as a total of nitrogen in both forms, that is, $\mathrm{NO}_{2}+\mathrm{NO}_{3}$ as $\mathrm{N}$. 

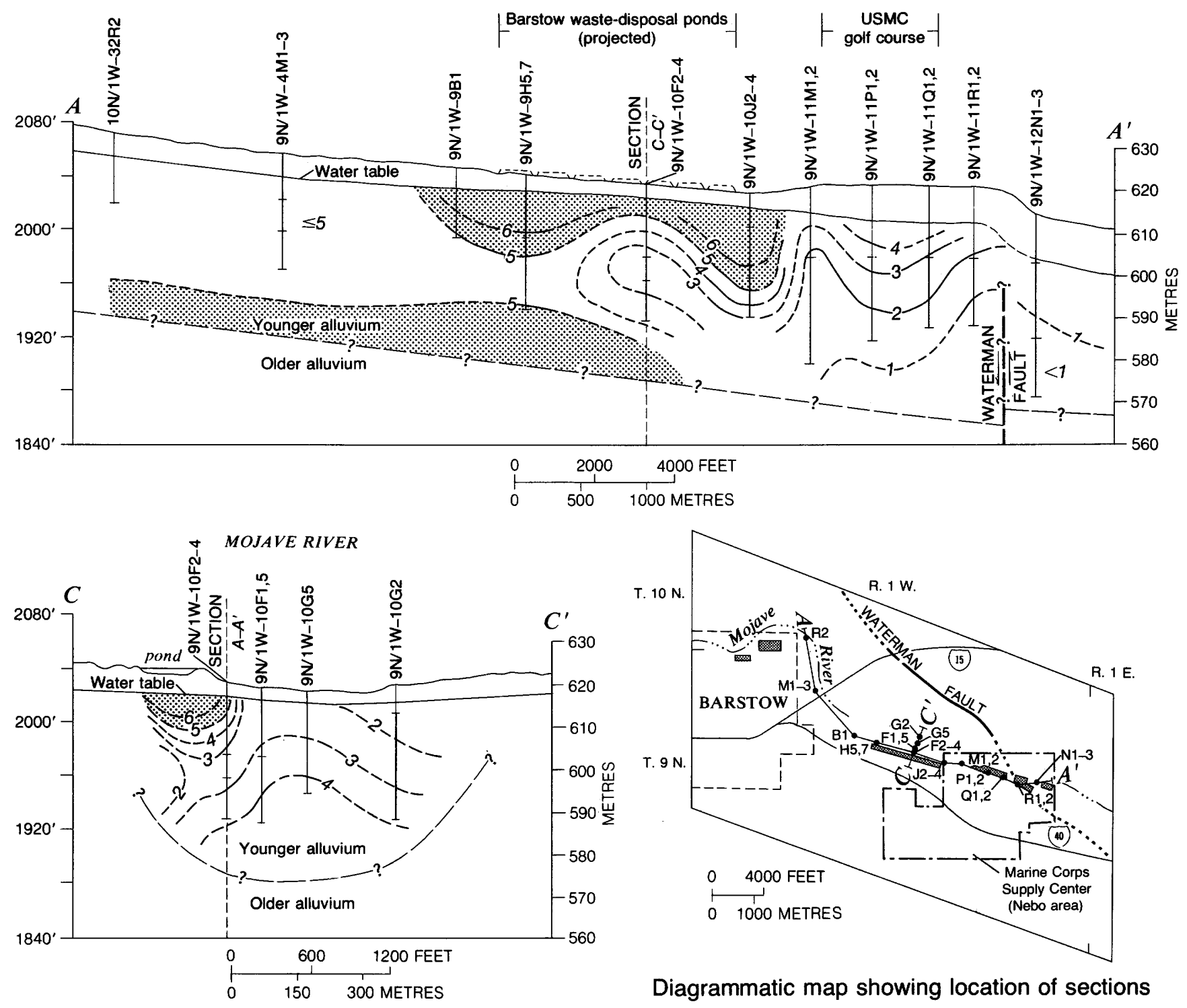

Diagrammatic map showing location of sections

EXPLANATION

\begin{abstract}
-6--- Line of equal dissolved-organic carbon concentration, March 1972 - Dashed where approximate; intervals in milligrams per litre, variable as shown

Areas of high dissolved-organic carbon concentration - Dissolved organic carbon $\geq 5.0 \mathrm{mg} / \mathrm{l}$
\end{abstract}

Waste-disposal sites - See figure 3

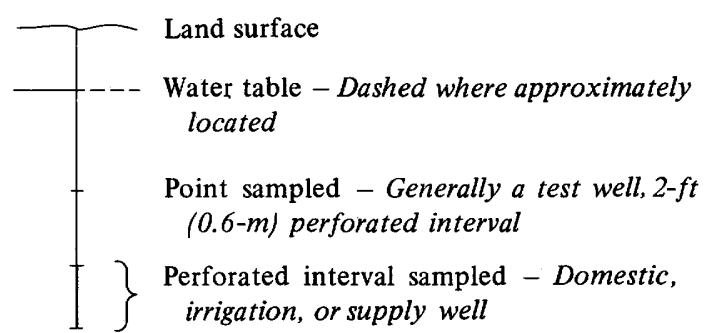
irrigation, or supply well

\section{DATUM IS MEAN SEA LEVEL VERTICAL SCALES EXAGGERATED}

FIGURE 9.-Vertical distribution of dissolved organic carbon.

section $A-A^{\prime}$, illustrates the degradation of ground water by nitrogen buildup that has resulted from irrigation return. In contrast, the near lack of nitrogen in ground water that has percolated from the present city sewage-treatment facilities (site $\mathrm{C}$, fig. 3 ) suggests that sewage treatment effectively reduces nitrogen by biological activity prior to percolation. The most probable explanation for the presence of nitrogen in 

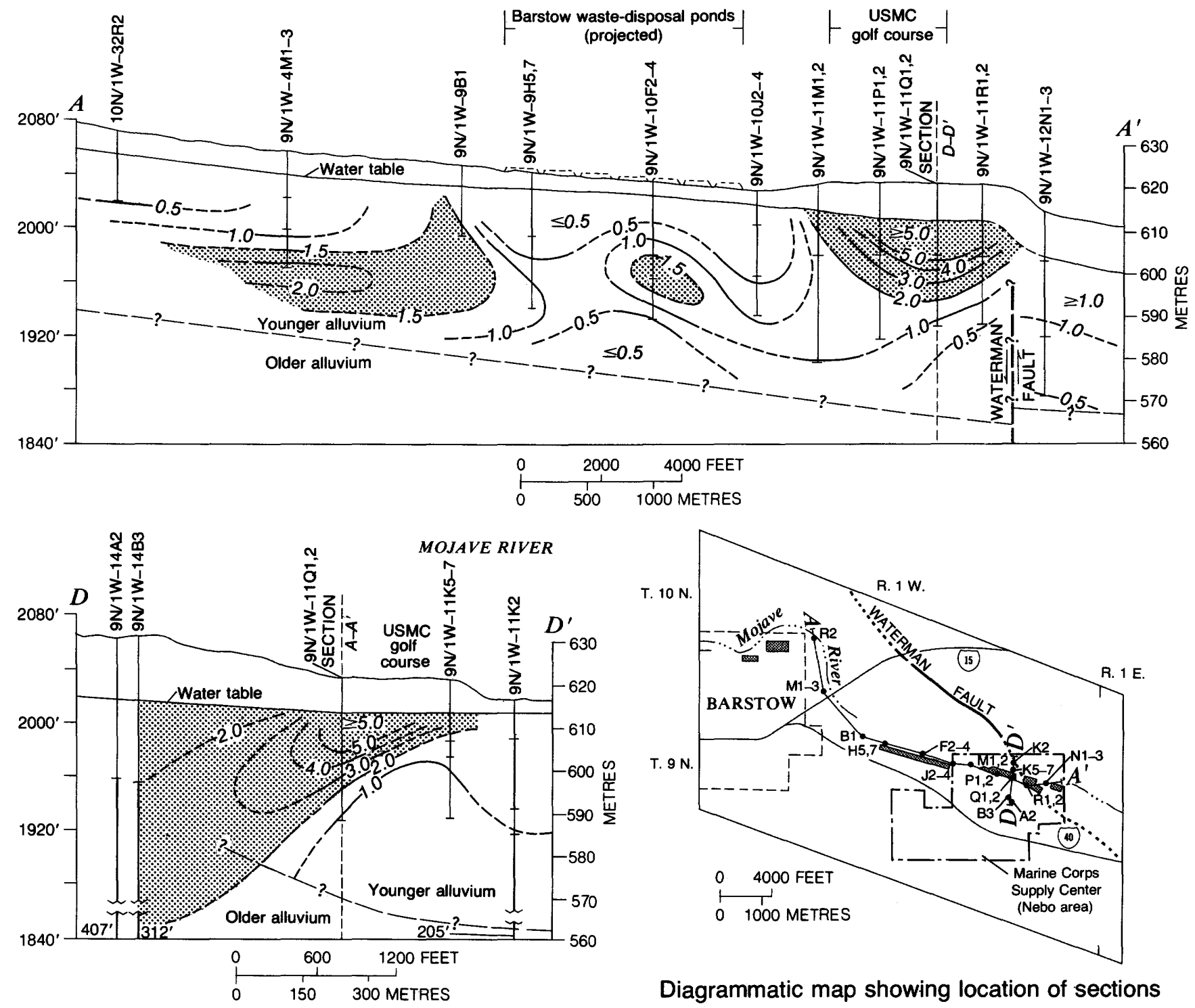

Diagrammatic map showing location of sections

\section{EXPLANATION}
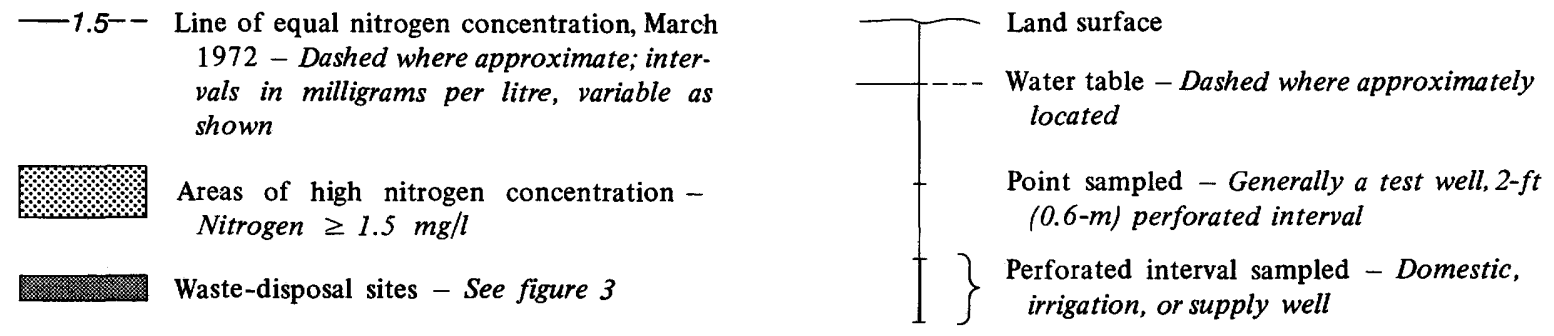

DATUM IS MEAN SEA LEVEL VERTICAL SCALES EXAGGERATED

FIGURE 10.-Vertical distribution of nitrogen.

irrigation-return water is that it is derived from soil, | MBAS), DOC, and chloride indicates low concentrations fertilizers, and decomposed plant matter. Comparison of the nitrogen distribution in section $A-A^{\prime}$ (fig. 10) with the same sections for dissolved solids, detergents (as of nitrogen in the shallow and deep saturated zones under the present city oxidation ponds. The chemical quality of ground water in these zones is influenced by 
past and present waste disposal. As previously noted, ground-water samples from wells $9 \mathrm{~N} / 1 \mathrm{~W}-9 \mathrm{H} 5$ and -10J3 closely reflect the chemical quality of waste percolation from the present city sewage-treatment facility. Nitrogen concentrations in water samples from these wells are low and are generally uniform (fig. 5). The slightly higher nitrogen concentrations in water samples from well $9 \mathrm{~N} / 1 \mathrm{~W}-9 \mathrm{H} 7$ may represent deep percolation of irrigation-return water in upstream areas.

The concentration of nitrogen in the ground water upstream from well 9N/1W-9B1 (fig. 10, section $A-A^{\prime}$ ) is moderately high and is comparable to irrigated areas. Extensive sprinkler irrigation of alfalfa in the northwest area of sec. 4 , T. 9 N., R. 1 W., may account for the concentration of nitrogen in wells $9 \mathrm{~N} / 1 \mathrm{~W}-4 \mathrm{M} 1,-4 \mathrm{M} 2$, and $-4 \mathrm{M} 3$. The concentration of nitrogen in the upper 50 $\mathrm{ft}(15 \mathrm{~m})$ of ground water beneath the Marine Corps golf course is probably a result of using nitrogen fertilizer. The use of fertilizer on the golf course is necessary to restore the nitrogen consumed or fixed by bacteria during the waste-water treatment process. Further investigation of this phase to discover the cause and effect of nitrogen use and buildup beneath the golf course might be worthwhile.

The deterioration in quality of ground water pumped from the USMC Supply Center wells has resulted in part from a hydraulic continuity between those wells and the poor quality water beneath the golf course. Section $D-D^{\prime}$ (figs. 10 and 11) suggests that the degraded water beneath the golf course has affected the quality of water from the USMC Supply Center's wells and had moved in response to pumpage. The concentration of nitrite plus nitrate as nitrogen $\left(\mathrm{NO}_{2}+\mathrm{NO}_{3}\right.$ as $\left.\mathrm{N}\right)$ in water pumped at the USMC Supply Center does not in itself directly pose a threat to domestic consumption (less than $10 \mathrm{mg} / \mathrm{l}$, table 2); however, the increase in dissolved solids and other specific constituents justifies concern for the water supply.

\section{CHLORIDE}

Chloride is a conservative ion because it will percolate through soil with few if any changes in concentration. "The chloride ion is probably the best tracer of ground water flow, for it is least affected by adsorption-desorption lag, or by other physical or chemical phenomena" (California Water Resources Control Board, 1963, p. 23). "Chloride, in the form of Cl ion, is one of the major inorganic anions $(-)$ which is increased in sewage over raw water because sodium chloride $(\mathrm{NaCl})$ is a common article of diet and passes unchanged through the digestive system" (American Public Health Association, 1971, p. 376). The conservative nature of the chloride ion may be indicated by values obtained from monthly sampling of wells in the project area (fig. 5).

Although limits set on the concentration of chloride vary for drinking water (table 1), it "is believed that the source of the chlorides may be a more important factor for drinking water than their quantity, and any sudden increase in chloride content of supply should be suspended as a possible indication of pollution $* * *$ " (California Water Resources Control Board, 1963, p. $160)$. Chemical analyses of water from the wells at the USMC Supply Center during the period 1953-72 indicate a gradual increase in the concentration of chloride. The longest available record of chemical analyses for a well at the USMC Supply Center (well $9 \mathrm{~N} / 1 \mathrm{~W}-13 \mathrm{E} 1$, drilled in 1954) indicates that the concentration of chloride has increased from $50 \mathrm{mg} / \mathrm{l}$ in 1954 to $180 \mathrm{mg} / 1$ in 1972 . Part of this increase in chloride is probably a result of the use of treated effluent on the golf course (section $D-D^{\prime}$, fig. 11). Because the source of the chloride ion can be more important than its concentration in evaluating water for human consumption, the effects of use of treated effluent high in dissolved solids and chemical constituents derived from domestic and industrial use on a golf course, or in any area that could affect a domestic water supply, should be carefully considered.

The distribution of chloride in section $A-A^{\prime}$ (fig. 11) is similar to the distribution of dissolved solids, MBAS, and DOC. Because chloride is a conservative ion and a potential indicator of water source (California Water Resources Control Board, 1963, p. 23), this relation offers support to the previous conclusions as to source and amount of those less conservative compounds.

\section{EFFECT OF PUMPAGE ON WATER QUALITY THE USMC SUPPLY CENTER}

Since 1954 the concentration of dissolved solids in ground water pumped from well $9 \mathrm{~N} / 1 \mathrm{~W}-13 \mathrm{E} 1$ at the USMC Supply Center has steadily increased from about $350 \mathrm{mg} / \mathrm{l}$ to more than $900 \mathrm{mg} / \mathrm{l}$ (fig. 12). The concern for the increase in dissolved solids and the appearance of some undesirable organic compounds (for example, phenols) is justified because poor-quality ground water is moving downstream in the direction of the USMC Supply Center's well field. The extent of degradation caused by the poor-quality ground water near the golf course and near the Barstow treatment facility (site C, fig. 3) depends largely on the area affected by pumping from wells at the USMC Supply Center.

Since 1962 the volume of ground water pumped annually at the USMC Supply Center (fig. 12) has increased from approximately 320 million gal $(12.1 \times$ $\left.10^{5} \mathrm{~m}^{3}\right)$ to 420 million gal $\left(15.9 \times 10^{5} \mathrm{~m}^{3}\right)$, an increase of about 40 percent in 10 years. The largest increase occur- 

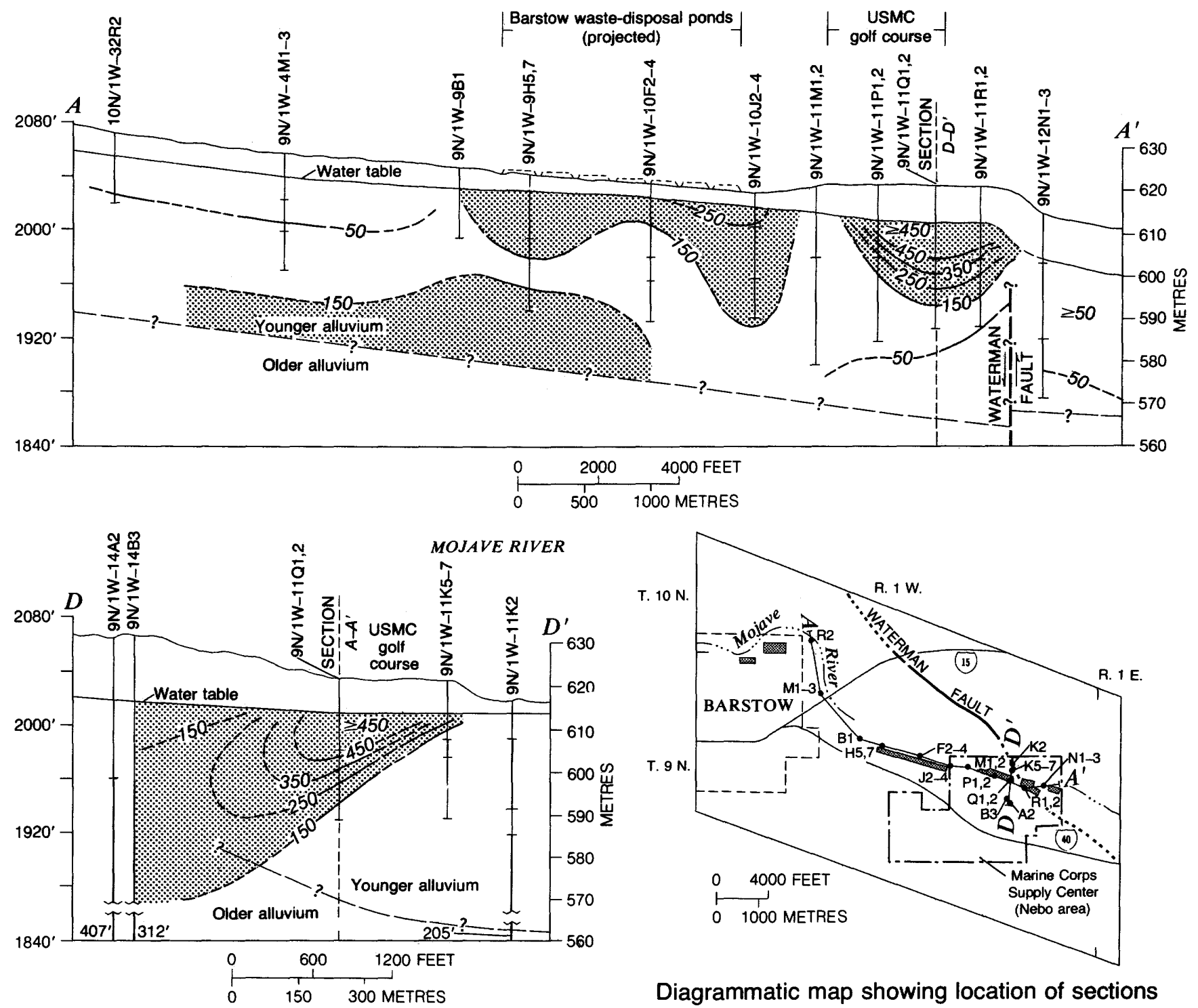

Diagrammatic map showing location of sections

\section{EXPLANATION}

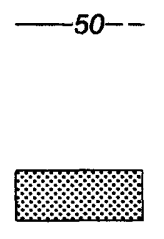

Line of equal chloride concentration, March 1972 - Dashed where approximate; inter. vals in milligrams per litre, variable as shown

Areas of high chloride concentration Chloride $\geq 150 \mathrm{mg} / \mathrm{l}$

Waste disposal sites - See figure 3

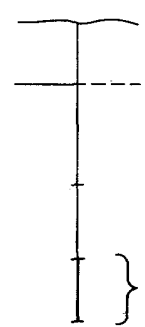

Land surface

Water table - Dashed where approximately located

Point sampled - Generally a test well, 2- $f t$ (0.6-m) perforated interval

Perforated interval sampled - Domestic, irrigation, or supply well

DATUM IS MEAN SEA LEVEL

VERTICAL SCALES EXAGGERATED

Figure 11--Vertical distribution of chloride.

red in 1966 when the pumpage for a single month|Supply Center have made it possible to increase was 72 million gal $\left(2.7 \times 10^{5} \mathrm{~m}^{3}\right)$. Recent additions to and modifications of the well system at the USMC pumpage and thereby make large demands on the local ground-water system. Nebo 1, a comparatively low- 

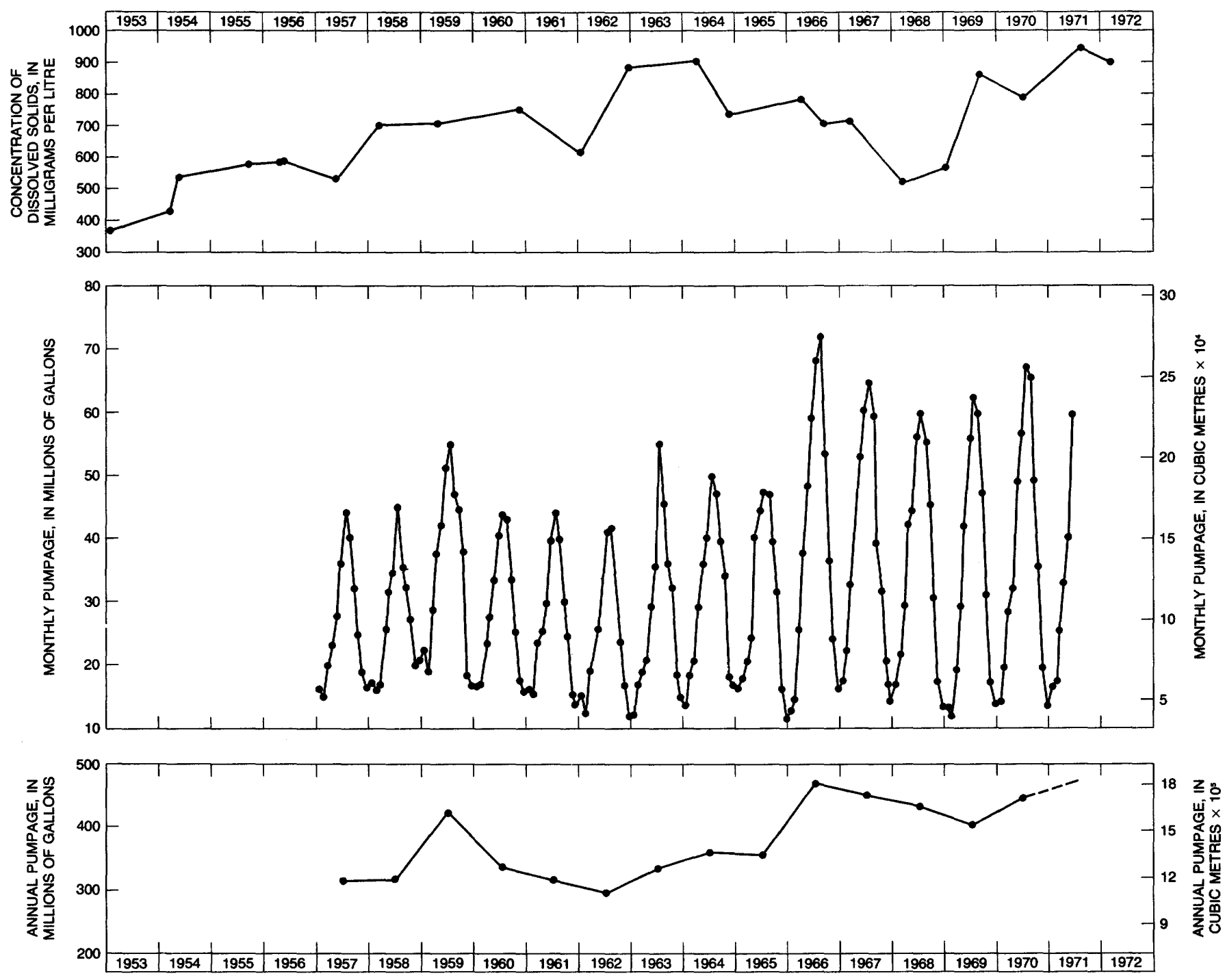

Figure 12.-Fluctuation of dissolved solids in well 9N/1W-13E1 (Nebo 4) and water-supply demands at the Marine Corps Supply Center (Nebo).

yielding well, was abandoned in 1968 and was replaced influenced by pumping and thereby to identify the in 1969 with a new, high-yielding well, Nebo 6 (table 8). Another well, Nebo 3, was reperforated and modified in 1972 to increase production.

An aquifer test was conducted at the USMC Supply Center in March 1972 to define the approximate area

TABLE 8.-Data on USMC Supply Center wells (Nebo)

\begin{tabular}{|c|c|c|c|c|c|c|}
\hline \multicolumn{2}{|c|}{ Well number } & \multirow{2}{*}{$\begin{array}{c}\text { Date } \\
\text { drilled }\end{array}$} & \multirow{2}{*}{$\underset{\text { (ft) }}{\text { Depth }}$} & \multirow{2}{*}{$\begin{array}{c}\text { Perfora- } \\
\text { tions } \\
(\mathrm{ft})\end{array}$} & \multirow{2}{*}{$\begin{array}{c}\text { Depth to } \\
\text { water (ft below } \\
\text { land surface } \\
\text { datum) }\end{array}$} & \multirow{2}{*}{$\begin{array}{c}\text { Pumping } \\
\text { rate } \\
\text { (gal/min) }\end{array}$} \\
\hline USMC & USGS & & & & & \\
\hline Nebo 1 & $9 \mathrm{~N} / 1 \mathrm{~W}-14 \mathrm{~B} 1$ & 1942 & 192 & $\begin{array}{r}70-151 \\
161-171\end{array}$ & 51.29 & --- \\
\hline $\begin{array}{l}2 \\
3 \\
4 \\
5 \\
6\end{array}$ & $\begin{array}{l}14 \mathrm{~A} 2 \\
14 \mathrm{~B} 2 \\
13 \mathrm{E} 1 \\
13 \mathrm{E} 2 \\
14 \mathrm{~B} 3\end{array}$ & \begin{tabular}{l}
$-\ldots 1942^{2}$ \\
$-\ldots 1947^{3}$ \\
\hdashline-1954 \\
$-\ldots 1961$ \\
$\ldots-1969$
\end{tabular} & $\begin{array}{l}408 \\
208 \\
348 \\
450 \\
336\end{array}$ & $\begin{array}{r}107-407 \\
37-280 \\
48-348 \\
65-440 \\
109-312\end{array}$ & $\begin{array}{l}61.13 \\
60.20 \\
61.10 \\
57.40 \\
52.35\end{array}$ & $\begin{array}{r}668 \\
386 \\
1,039 \\
585 \\
770\end{array}$ \\
\hline
\end{tabular}

${ }^{1}$ Measured March 29-April 1972. possible source or sources affecting the quality of water at the base. USMC supply wells $9 \mathrm{~N} / 1 \mathrm{~W}-13 \mathrm{E} 1,-13 \mathrm{E} 2$, $-14 \mathrm{~A} 2$, and -14B3 (table 8), which were pumped at full capacity for 96 hours, discharged a total of about 11 million gallons $\left(4.2 \times 10^{4} \mathrm{~m}^{3}\right)$. Response of groundwater levels to the discharge was measured in the four pumping wells and in 17 nonpumping observation wells. The combined discharge from the pumping wells is comparable to peak water-supply demands at the USMC Supply Center during the summer (fig. 12). Test results were used to delineate an area of drawdown equal to or greater than $0.25 \mathrm{ft}(0.08 \mathrm{~m})$ as shown in figure 13. Initially, most of the water-level decline was in the immediate area of the pumping wells. As pumping continued, water-level declines extended 


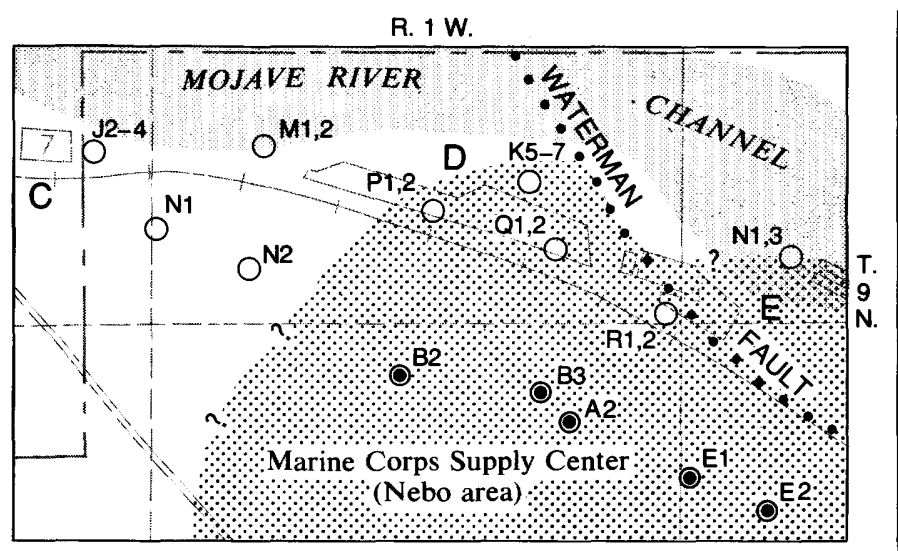

Base from U.S. Geological Survey Daggett 1:62 500, 1956

Roads as of 1972

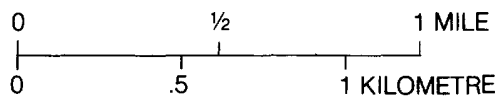

\section{EXPLANATION}

$\bullet \cdot \bullet \cdot \bullet$

Concealed fault

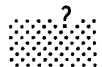

Area affected by drawdown in well

Drawdown equal to or greater than $0.25 \mathrm{ft}$ $(0.08 \mathrm{~m})$. Queried where doubtful

$$
\mathrm{O}^{\mathrm{A} 2}
$$

USMC supply well

$$
\mathrm{O}^{\mathrm{N} 1}
$$

Observation well

FIGURE 13.- Area affected by a 96-hour aquifer test at U.S. Marine Corps Supply Center. Waste-disposal sites (C, D, E) as identified in figure 3.

outward. After the drawdown cone was subjected to the barrier effect to ground-water flow caused by the Waterman fault, the area affected by the pumping extended northwestward along the fault at a greater rate than on the downstream side. The shape of the cone of depression south and east of the well field could not be observed because of the lack of wells in those areas.

Although the aquifer along the Mojave River north and west of the USMC Supply Center's well field is capable of supplying large quantities of water, water in this area is also potentially the most detrimental to the quality of water pumped at the USMC base. Percolation from the present waste-disposal facilities for the city of Barstow, a plume of older, degraded water in the river-channel deposits, and the USMC Supply Center's golf course are in this direction. Therefore, unless some changes are made to alter ground-water flow paths, the water pumped at the USMC Supply Center can be expected in future years to increase in dissolved solids, chloride, and those compounds indicated by DOC. Because of the proximity of the USMC golf course, it seems that degraded ground water from this source would first reach the USMC supply wells.

As stated earlier, the city of Barstow sewagetreatment facility is currently (1972) completing modification of its plant to provide full secondary treatment of domestic and industrial wastes. This reconstruction is designed to improve the quality of effluent for percolation. The USMC Supply Center stopped the use of treated effluent on the golf course in October 1972. The use of fresh water on the golf course will probably not improve the quality of water pumped at the USMC Supply Center immediately, although with time the general quality of ground water in the vicinity of the golf course will probably improve. The combined effects of percolating effluent of better quality by the city of Barstow and by the USMC Supply Center will be to improve the quality of water in the shallow groundwater zones.

\section{RATE OF GROUND-WATER MOVEMENT}

The average velocity of ground water in the riverchannel deposits has been estimated by interpretation of both hydrologic and chemical data. Ground-water velocities estimated from hydrologic data indicate a flow rate of approximately $1.0 \mathrm{ft}(0.3 \mathrm{~m})$ per day. The hydrologic data used in this estimate were generated by a digital model of the ground-water system in the project area (S. G. Robson, written commun., 1972).

The velocity of ground-water flow was also estimated by comparing the present downstream location of the degraded plumes with the first records of waste disposal at specific sites in the alluvial deposits. The nose of the plume outlined by DOC (fig. 7) is approximately $4.5 \mathrm{mi}$ $(7.2 \mathrm{~km})$ below the point where the railroad reportedly first began to discharge wastes. Assuming about 60 years has elapsed since that discharge began, a downgradient maximum velocity of about $1.0 \mathrm{ft}(0.3 \mathrm{~m})$ per day would be required to achieve the present downstream location of the DOC plume. A similar computation using detergents (as MBAS) indicated that a downgradient maximum velocity of approximately 1.5 $\mathrm{ft}(0.46 \mathrm{~m})$ per day would be required to account for the downstream location of the plume (fig. 7). This estimate assumes that synthetic detergents were first used in the Barstow area in 1945 and that the city of Barstow's facility at site B (fig. 3 ) was the point of waste discharge.

\section{SUMMARY}

The degraded ground water that has resulted from municipal and industrial waste discharge in the Barstow area has been delineated both areally and 
vertically for the period March-April 1972. The quality of water in the river-channel deposits is part of a dynamic system and is constantly changing in response to changes in quality and quantity of recharge and location of waste water and irrigation-return water.

The distribution of chemical quality in the riverchannel deposits indicates that an old plume of degraded water is moving near the base of the alluvial aquifer. Since 1910 this degraded plume has moved downgradient about $4.5 \mathrm{mi}(7.2 \mathrm{~km})$. A more recent overlying plume of degraded water occurs near the downstream edge of the deeper plume. This plume has been produced by percolation from sewage-treatment facilities installed in 1968. Interpretation of hydrologic and chemical data indicates that the rate of movement in the deeper zone of degraded ground water is $1.0-1.5 \mathrm{ft}$ $(0.3-0.46 \mathrm{~m})$ per day. Providing that the present (1972) conditions of recharge and discharge continue, it can be expected that the water supply at the USMC Supply Center will significantly reflect the poor quality ground water in the river-channel deposits within the next few years, even though the quality of the ground water in the shallow zones beneath the golf course may improve.

Distribution of nitrogen and chloride in the ground water suggests that the gradual increase in dissolvedsolids concentrations in the USMC Supply Center's wells has resulted in part from the use of treated sewage effluent on the USMC golf course.

\section{SELECTED REFERENCES}

American Public Health Association, 1971, Standard methods for examination of water and wastewater [13th ed.]: $874 \mathrm{p}$.

American Water Works Association, 1971, Water quality and treatment [3d ed.]: McGraw-Hill Publishing Co., 654 p.

Bader, J. S., Page, R. W., and Dutcher, L. C., 1958, Data on wells in the upper Mojave Valley area, San Bernardino County, California: U.S. Geol. Survey open-file report, 238 p.

Brown, K. W., and Caldwell, D. H., 1970, Domestic and industrial waste study, Marine Corps Supply Center, Barstow, California: Consulting rept. to U.S. Marine Corps, 66 p., app. A-G.

California Department of Public Health, 1966, Barstow ground-water study: Rept. to Lahontan Regional Water Quality Control Board, 12 p. and 7 tables.

-1970, Barstow ground-water study: Rept. to California Regional Water Quality Control Board, Lahontan Region, 14 p.

California Department of Public Health and California Department of Water Resources, 1960, Ground-water quality studies in Mojave River valley in vicinity of Barstow, San Bernardino County: Rept. to Lahontan Regional Water Quality Control Board, 60 p. and app.

California Department of Public Works, Division of Water Resources, 1952, Investigation of Mojave River, Barstow to Yermo: Rept. to Lahontan Regional Water Quality Control Board, $40 \mathrm{p}$.

California Department of Water Resources, 1967, Mojave River ground-water basins investigations: California Dept. Water Resources, Bull. 84, 151 p.

California Water Resources Control Board, 1963, Water quality criteria, edited by J. E. McKee and H. W. Wolf [2d ed.]: Pub. 3-A, 548 p. (repr. 1971).

-1969, The Porter-Cologne Water Quality Control Act: Rept. to Regional Water Quality Control Boards, $44 \mathrm{p}$.

Dyer, H. B., Bader, J. S., Giessner, F. W., and others, 1963: Data on wells and springs in the lower Mojave Valley area, San Bernardino County, California: California Dept. Water Resources Bull. 91-10, 212 p.

Halvorson, Harvest, and Ishaque, M., 1969, Microbiology of domestic wastes. III. Metabolism of LAS-type detergents by bacteria from sewage lagoon: Canadian Jour. Microbiology 15, p. 571-576.

Hardt, W. F., 1969, Mojave River basin ground-water recharge with particular reference to the California floods of January and February 1969; U.S. Geol. Survey open-file report, 13 p. 1971, Hydrologic analysis of Mojave River basin, California, using electric analog model: U.S. Geol. Survey open-file report, $84 \mathrm{p}$.

Hughes, J. L., and Patridge, D. L., 1973, Selected data on wells in the Barstow area, Mojave River basin, California: U.S. Geol. Survey open-file report, $102 \mathrm{p}$.

Hughes, J. L., and Robson, S. G., 1973, Effects of waste percolation on ground water in alluvium near Barstow, California, in Underground waste management and artificial recharge-International Symposium: Am. Assoc. Petroleum Geologists, U.S. Geol. Survey, and Internat. Assoc. Hydrol. Sci., v. 1, p. 91-129.

Koehler, J. H., 1969, Water resources at the Marine Corps Supply Center, Barstow, California for the 1968 fiscal year: U.S. Geol. Survey open-file report, $16 \mathrm{p}$.

Malcolm, R. L., and Leenheer, J. A., 1972, Organics Task Group: U.S. Geol. Survey Research Note 112, 3 p.

Meyer, C. B., and Horn, W. L., 1955, Water utilization and requirements of California: California Water Resources Control Board, Bull. 2, v. 1, 227 p.

Miller, G. A., 1969, Water resources of the Marine Corps Supply Center area, Barstow, California: U.S. Geol. Survey open-file report, $51 \mathrm{p}$.

Page, R. W., and Moyle, W. R., Jr., 1960, Data on wells in the eastern part of the middle Mojave Valley area, San Bernardino Co., California: California Dept. Water Resources Bull. 91-3, 223 p.

Page, R. W., Moyle, W. R., Jr., and Dutcher, L. C., 1960, Data on wells in the west part of the middle Mojave Valley area, San Bernardino County, California: California Dept. Water Resources Bull. 91-1, 126 p.

Robson, S. G., 1974, Feasibility of digital water-quality modeling illustrated by application at Barstow, California: U.S. Geol. Survey Water-Resources Inv. 46-73, 66 p.

Thompson, D. G., 1929, The Mohave Desert Region, California, a geographic, geologic, and hydrologic reconnaissance: U.S. Geol. Survey Water-Supply Paper 578, 759 p.

Thornthwaite, C. W., 1948, An approach toward a rational classification of climate: Geographic Review, v. 38, no. 1, p. 55-94.

U.S. National Weather Service, 1972, Climatological data, Washington: U.S. Weather Bur. mo. rept.

U.S. Public Health Service, 1962, Drinking water standards, 1962: Pub. 956, 61 p.

- 1969, Observations of Continental European solid waste management practices: Pub. 1880,46 p. 


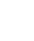

1 